\title{
IN VIVO AND IN VITRO DIGESTIBILITY OF A COMPLETE PELLETED FEED
} IN HORSES

\author{
A Thesis \\ presented to \\ the Faculty of California Polytechnic State University \\ San Luis Obispo, CA
}

\begin{abstract}
In Partial Fulfillment
of the Requirements for the Degree

Master of Science in Agriculture with Specialization in Animal Science
\end{abstract}

by

Cassandra Renee Sweeney

August, 2012 
(C) 2012

Cassandra Renee Sweeney ALL RIGHTS RESERVED 


\section{COMMITTEE MEMBERSHIP}

TITLE: COMPLETION OF AN IN VIVO DIGESTIBILITY TRIAL IN HORSES AND IN VITRO DIGESTIBILITY ASSAY DEVELOPMENT

AUTHOR: $\quad$ Cassandra Renee Sweeney

DATE SUBMITTED: $\quad$ August, 2012

COMMITTEE CHAIR: Dr. Mark Edwards

COMMITTEE MEMBER: Dr. Robert Delmore

COMMITTEE MEMBER: Dr. Gustavo Lascano 


\section{ABSTRACT \\ COMPLETION OF AN IN VIVO DIGESTIBILITY TRIAL IN HORSES AND IN VITRO DIGESTIBILITY ASSAY DEVELOPMENT}

Cassandra Renee Sweeney

In vivo analysis of equine feed digestibility has been the gold standard since the late 1800's, although it can be time consuming, costly, and labor intensive. In vitro digestibility analysis may be more economical and beneficial to both feed manufacturers and consumers. The availability of accurate in vivo data is crucial for critical evaluation and validation of any potential in vitro method (Coles et al., 2005). Ten adult American quarter horse geldings were used in the in vivo digestibility evaluation of two complete pelleted feeds fed as $100 \%$ of intake. The ingredients of the two treatments were similar: wheat middlings, rice hulls, alfalfa and beet pulp. The treatments differed in added mineral sources, yeast, direct fed microbials, and Yucca schidigera extract, added to enhance dry matter digestibility of the test diet. The in vivo evaluation consisted of two phases in a randomized crossover design. Total daily dry matter intake (DMI) and daily dry matter excretion (DME) were measured. Apparent digestibility (aDig) of \% DM, \% NDF, \% ADF, \% ADL om, and \% OM (DM) were also calculated. No differences were seen in aDig of NDF, $A D F, A D L_{O M}$ or $\mathrm{OM}$ between the two experimental diets $(P>0.05)$. There was also no difference in DMI or DME, as a percentage of body weight (BW), between the two experimental diets. The effect of phase was not significant for all tests run on aDig, DMl, and DME $(P>0.05)$. BW was not significantly different $(P>0.05)$ between diets, however there was a trend for 
heavier BW during phase $2(P=0.073)$. In vitro digestibility assay development followed the in vivo evaluation. A three-stage batch system as briefly described by Boisen and Fernandez (1997) was utilized. Through literature review, trial and error, personal communication with other labs and product and chemical manufactures, careful documentation of the methods were detailed. Using the control feed from the in vivo evaluation, variation in the methods was significantly reduced, and estimations of DML began to approach those seen in vivo throughout method development. Although further method development may be needed for species-specific use, the methods described here can provide the foundation for future in vitro digestibility studies. 


\section{ACKNOWLEDGMENTS}

I would like to thank Dr. Mark Edwards for all his patience and guidance throughout my career as a graduate student. Dr. Edwards goes above and beyond for the students he advises allowing each one to learn individually. Dr. Edwards demonstrates exemplary professionalism while maintaining a sense of humor which was always appreciated at those sunrise to sunset collection days! Most importantly Dr. Edwards acts as a role model for what it means to be a good scientist.

Laura Bauer at Illinois State University was instrumental in the in vitro methods described in this paper. Her kindness and expertise are greatly appreciated, we could not have done it without you!

A special thank you to Dr. Delmore and Dr. Lascano for agreeing to serve on my committee so late in the process, I really appreciate your help.

I would like to thank Laura Lickel and Amanda Phipps, fellow graduate students who provided constant support. Both Laura and Amanda were instrumental in the in vivo and in vitro work described, volunteering countless hours to see the projects through.

I would also like to thank all the undergraduate students who were the cornerstone of these projects. We literally could not have done it without them and I am absolutely grateful for all their hard work and dedication. 
My sincere appreciation is also given to Dr. Mary Beth Gordon and Purina Land O' Lakes Feed for allowing me to conduct this study within and alongside their larger feeding trials. A study of this magnitude would not have been possible without your support.

Finally I would like to thank my husband Michael for all his ongoing support and encouragement in the pursuit of this degree, I would not have been able to do it without you. Also a special thank you to my Mom, for visiting me at the barn on holidays and volunteering her help. Thank you! 


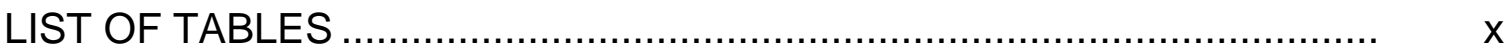

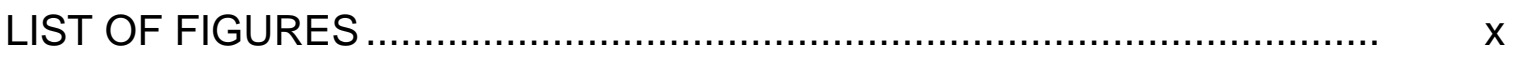

LIST OF ABBREVIATIONS .................................................................. xii

CHAPTER

I. LITERATURE REVIEW ......................................................

II. IN VIVO EVALUATION ............................................................... 22



Methods ............................................................................ 22

Statistical Analysis ......................................................... 32

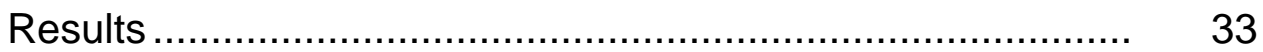

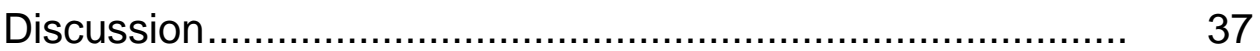

III. IN VITRO EVALUATION ........................................................... 40

Methods ...................................................................... 40

Results.................................................................. 47

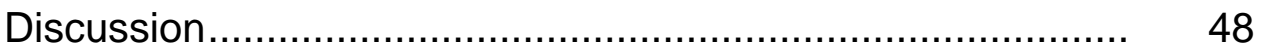

V. CONCLUSIONS ............................................................. 56

LITERATURE CITED …........................................................... 59

\section{APPENDICES}

A. In Vitro Evaluation Method Development .............................. 67

B. In Vitro Procedure ........................................................... 76

C. $\quad 95 \%$ and $78 \%$ Ethanol....................................................... 80

D. Phosphate Buffer .............................................................. 81

E. $\quad \mathrm{HCl}$ Pepsin Solution ............................................................. 83

F. Chloramphenicol Solution ................................................ 84 
G. Sodium Hydroxide Solution ................................................ 85

H. Pancreatin Phosphate Buffer ........................................... 86

I. Mineral Solution A .......................................................... 88

J. $\quad$ Mineral Solution B ....................................................... 90

K. Trace Mineral Solution ..................................................... 91

L. Water Soluble Vitamin Solution............................................ 93

M. Vitamin B-12 Solution..................................................... 95

N. Folate-Biotin Solution ......................................................... 96

O. Riboflavin Solution .............................................................. 97

P. Hemin Solution ........................................................... 98

Q. Short Chain Fatty Acid Mix................................................ 99

R. Resazurin Solution 0.1\% ................................................ 100

S. Media .............................................................................. 101

T. $\quad$ Mineral Solution 1 ......................................................... 104

U. $\quad$ Mineral Solution 2 ........................................................... 105

V. Sodium Bicarbonate Solution ............................................. 106

W. Anaerobic Diluting Solution .................................................. 107

X. Fecal Inoculumn ......................................................... 109

Y. National Forage Testing Association Procedure 2.2.2.2. ....... 111

Z. National Forage Testing Association Procedure 942.05 ........ 115 


\section{LIST OF FIGURES}

Page

Figure 1 Illustration of the equine digestive tract with relative volumes indicated in parentheses. (Frape, 2004).

Figure 2 Average \% DML ( \pm SD) and average \% OML ( \pm SD) after stage 3 using the control feed. Attempts 1-5 correspond to method development, attempts 6-8 correspond to sets 1-3 of final reported results for stage 3.

Figure 3 Average \% DML ( \pm SD) after stage 2 using the control feed. Attempts 1-10 correspond to method development, attempt 11 corresponds to final reported results for stage 2 .

\section{LIST OF TABLES}

Table 1 Measurement of five pancreatic enzymes from the Page adult equine $(n=7)$ and porcine $(n=12)$ pancrease. Values are enzyme activity expressed as mean units per milligram of DNA. Adapted from (Lorenzo-Figueras et al., 2007).

Table 2 Measurements of cecal $\mathrm{pH}$ in the equine and diet fed.

Table 3 Select nutrient composition of the experimental diets, on a dry matter basis (DMB) except dry matter (DM).

Table 4 Phases of the in vivo diet evaluation detailing stages within each phase and objective and duration for each.

Table 5 Mean $( \pm$ SD) composition of the experimental diets, on a dry matter basis (DMB) except dry matter (DM).

Table $6 \quad$ Mean \% aDig DM $( \pm$ SD) of the experimental diets. ( $n$ $=17$ ) for each diet. Includes harness success values of Off. 


\section{List of Tables (Continued)}

Table $7 \quad$ Mean $\%$ aDig DM $_{\text {( }} \pm \mathrm{SD}$ ) by harness success, of the experimental diets.

Table 8 Mean \% aDig ( \pm SD) of DM, NDF, ADLom, and $\mathrm{OM}$, of the experimental diets $\mathrm{n}=10$ for each diet. Includes harness success values of On only.

Table 9 Average DMI $( \pm$ SD) and DME $( \pm$ SD) as a percentage of $B W$ of DM, NDF, ADLom, and $\mathrm{OM}$, of horses consuming the experimental diets. $\mathrm{n}=10$ for each diet. Includes harness success values of On only.

Table 10 Average BW $(\mathrm{kg})( \pm \mathrm{SD})$ of horses consuming the experimental diets ( $n=10$ for each diet).

Table 11 Average BW $(\mathrm{kg})( \pm \mathrm{SD})$ of horses consuming the experimental diets during each phase $(\mathrm{n}=$ 10 for each phase).

Table 12 Comparisons of aDig (DM basis) of pelleted feeds for DM, NDF, and ADF between studies.

Table 13 Composition of anaerobic media used in stage 3.

Table 14 Composition of anaerobic diluting solution used to dilute feces in stage 3 .

Table 15 Average \% DML ( \pm SD) and average \% OML $( \pm$ $\mathrm{SD}$ ), with corresponding $\% \mathrm{CV}, \mathrm{n}=5$ for each set. 


\section{LIST OF ABBREVIATIONS}

$\begin{array}{ll}\text { aDig } & \text { Apparent digestibility } \\ \text { aDigDM } & \text { Apparent digestibility of dry matter } \\ \text { ADF } & \text { Acid detergent fiber } \\ \text { ADL } & \text { Acid detergent lignin } \\ \text { ADLOM } & \text { Acid detergent lignin on an organic matter basis } \\ \text { BW } & \text { Body weight } \\ \text { DE } & \text { Digestible energy } \\ \text { DM } & \text { Dry matter } \\ \text { DMB } & \text { Dry matter basis } \\ \text { DME } & \text { Dry matter excretion } \\ \text { DMI } & \text { Dry matter intake } \\ \text { DML } & \text { Dry matter loss } \\ \text { NDF } & \text { Neutral detergent fiber } \\ \text { OM } & \text { Organic matter } \\ \text { OML } & \text { Organic matter loss } \\ \end{array}$




\section{LITERATURE REVIEW}

\section{Introduction}

In 2005, there were over 9 million horses in the United States, with at least $39 \%$ involved in performance activities (American Horse Council Foundation, 2005). Also in 2005, the sale of horse related goods, including feed, contributed over $\$ 21$ million to the gross domestic product (American Horse Council Foundation, 2005). The average horse owner in the United States spends over $\$ 500$ per horse annually on feed, bedding, and grooming supplies (American Horse Council, 2005). In the 2009-2010 Equine Horse Publications survey, $74 \%$ of respondents stated their spending on equine feeds and concentrates has increased over the past year. There are also increased numbers of choices for horse owners when selecting equine feeds and concentrates. Because horses are not a production species, many feeds are formulated and sold without first researching their digestibility, suggesting an increased need for equine nutrition research.

In animal nutrition, digestibility is defined as the percentage of the feed or of a single nutrient in the feed that is acted on in the digestive tract, absorbed, and made available for use by the body's cells (Schneider and Flatt, 1975). Digestibility analysis is essential when developing or reformulating equine feeds (Lowman et al., 1999), as it allows the manufacturer to pass on vital feeding

recommendations to customers. Digestibility information is also important economically to the consumer because accurate feeding guidelines reduce 
overfeeding and waste (Schneider and Flatt, 1975). Because nutrient composition and digestibility can vary within single ingredients and batch of processed feed, manufacturers and distributors also benefit economically when ingredient digestibility and cost are considered together before producing a diet (Schneider and Flatt, 1975). Digestibility analysis can be completed using in vivo or, alternatively, in vitro techniques.

In vivo analysis of equine feed digestibility has been the gold standard since the late 1800 's, although these methods can be time consuming, costly, and labor intensive. Additionally it is desirable to limit the use of animals in research whenever possible on the basis of animal welfare. In vivo methods could address many of these concerns, however, the availability of accurate in vivo data is crucial for critical evaluation and validation of any potential in vitro method (Coles et al., 2005).

In vitro digestion methods have been widely used and refined for ruminants since their development (Tilley and Terry, 1963). Currently there is no standard accepted in vitro method for digestibility analysis of equine feeds. While recent studies show promising advancement in the area, refinement of current methods for use in the equine are not yet complete or validated against in vivo digestibility. A reliable in vitro digestibility method would provide timely and cost-efficient evaluation of nutrient behavior in vivo and also allow for quality control of processed feeds (Schneider and Flatt, 1975). 


\section{Physiology and Function of the Equine Gastrointestinal Tract Characterization}

Horses are classified as monogastric herbivores, having a stomach with a single compartment (Figure 1) (Pond et al., 2005). Additionally, they are considered a hindgut colonic fermenter, with extensive fermentation occurring in the cecum (Pond et al., 2005; Stevens and Hume, 1995). The following outline details the physiological function of (and passage of digesta through) the equine digestive tract. Details that may be helpful in developing an equine in vitro digestibility method are also given. 


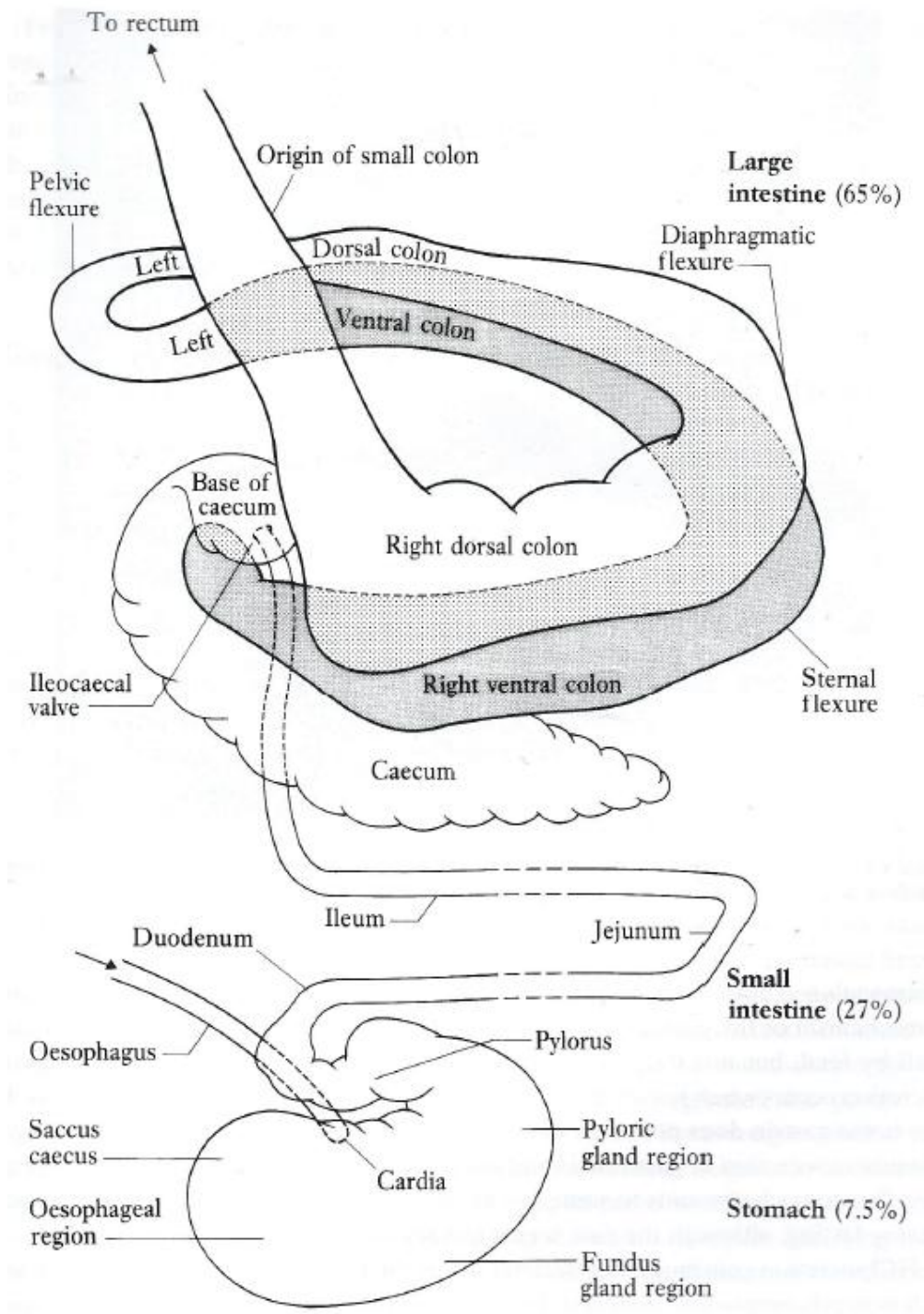

Figure 1. Illustration of the equine digestive tract with relative volumes indicated in parentheses. (Frape, 2004).

\section{Saliva}

A horse secretes 10-12 liters of saliva per day, stimulated by mastication, and saliva is continuously secreted during feeding (Frape, 2004; Alexander and Hickson, 1969). Equine saliva contains low levels of enzymes, if any, and the enzymatic activity of saliva is probably of minor significance for the digestive 
process (Hintz, 1990; Frape et al., 2004). Salivary sodium bicarbonate and sodium chloride content act as a buffering agent for digesta in the proximal region of the stomach (Frape, 2004), although the $\mathrm{pH}$ of saliva has a wide range and varies greatly between individuals (Ellis and Hill, 2005). Alexander (1966) measured the $\mathrm{pH}$ of equine saliva from the parotid gland as averaging 7.49 over 24 hours $(n=2)$. However, saliva containing more mucus is secreted from the sublingual and mandibular glands (Ellis and Hill, 2005), suggesting measurements of salivary $\mathrm{pH}$ from only one gland is not an accurate representation of overall salivary $\mathrm{pH}$.

\section{Esophagus}

The equine esophagus is approximately $120-150 \mathrm{~cm}$ in length (Ellis and Hill, 2005). The esophagus is comprised of multiple layers, the innermost mucosal layer containing stratified epithelium (Ellis and Hill, 2005). Peristaltic waves move digesta through the cardiac sphincter into the stomach (Colville and Bassert, 2002; Ellis and Hill, 2005). Because of the strong cardiac sphincter and muscle in the lower esophagus, reflux and vomiting are very rare in the horse (Colville and Bassert, 2002; Hintz, 1990).

\section{Stomach}

The equine stomach is sharply curved and lies between the esophagus and small intestine (Ellis and Hill, 2005). The equine stomach comprises approximately $10 \%$ of the gastrointestinal tract volume (Frape, 2004) and is 
relatively small in size compared to other species. A significant portion of digesta may remain in the equine stomach for up to $6 \mathrm{~h}$, and the stomach is never completely empty (Frape, 2004). Because of the small stomach size and fast rate of passage, protein digestion in the equine stomach is minimal (Frape, 2004).

In the equine stomach, less than half the mucosal surface is lined with glandular epithelium (Frape, 2004). The glandular mucosa is divided into fundic and pyloric regions (Frape, 2004). The pyloric region secretes the hormone gastrin into the blood plasma (Frape, 2004). Gastrin controls the release of hydrochloric acid from the parietal cells in the fundic mucosa. The fundic mucosa also contain zymogen cells that secrete pepsinogen (Frape, 2004). Pepsinogen is activated to pepsin by the acidic environment of the stomach, which causes hydrolysis of peptide bonds in amino acids (Stevens and Hume, 1995; Argenzio, 1990). Pepsin is most active at $\mathrm{pH} 2$ to 4 (Stevens and Hume, 1995), and its activity is up to 20 times greater in the pyloric than in the fundic region (Frape, 2004).

The differences between the $\mathrm{pH}$ in the fundic region, 5.4, and pyloric region, 2.6, is mainly a function of saliva buffering digesta in the fundic region, stratification of digesta (Frape, 2004), and the curvature of the stomach (Ellis and Hill, 2005). When nearly empty, the $\mathrm{pH}$ in the stomach is $1.5-2.0$ due to the continued secretion of hydrochloric acid (Frape, 2004). When horses were fed hay, the median $\mathrm{pH}$ in the stomach over 24 hours was 3.1, with a typical increase after feeding from $<2.0$ to $>5.0(n=5)$ (Murray and Schusser, 1993). 


\section{Midgut / Small Intestine}

The main site for digestion and absorption of hydrolyzable carbohydrates, protein and lipids is the small intestine (NRC, 2007). Secretions from the pancreas and liver are responsible for the initial breakdown of these components (Argenzio, 1990). The equine small intestine is responsible for approximately $60-70 \%$ of protein digestion and absorption, $65-75 \%$ of soluble carbohydrates, and $15-25 \%$ of fiber (Hintz, 1990). The small intestine is also the primary site of dietary fat digestion and absorption (Hintz, 1990).

Passage of digesta into the small intestine is controlled by the pyloric sphincter. An average $450 \mathrm{~kg}$ horse has a short small intestine, 21-25 m total length, within which digesta moves at a rate of nearly $30 / \mathrm{cm} / \mathrm{min}$ (Frape, 2004). The small intestine is separated into the fixed part, the duodenum, and the meosenteric part, the jejunum and ileum (Ellis and Hill, 2005). The duodenum in the horse is between 1-1.5 meters in length (Ellis and Hill, 2005). The horse does not have a gall bladder; bile and pancreatic secretions are continuously secreted directly into the duodenum via a common duct (Frape, 2004; Ellis and Hill, 2005). The ileum is a major site of protein digestion and amino acid absorption (Ellis and Hill, 2005).

The $\mathrm{pH}$ of digesta entering the small intestine ranges from 2.5 to 3.5 (Ellis and Hill, 2005), and is rapidly buffered to about 7.0 (Frape, 2004). Pancreatic secretions into the duodenum appear to have low enzyme activity compared to 
other species (Argenzio, 1990; Frape, 2004; Lorenzo-Figueras et al., 2007; Alexander and Hickson, 1969). In a recent study by Lorenzo-Figueras et al. (2007) the specific enzyme activity of five pancreatic enzymes (amylase, lipase, elastase, trypsin, chymotrypsin) was higher for swine than for horses (Table 1).

Table 1. Measurement of five pancreatic enzymes from the adult equine $(n=7)$ and porcine $(n=12)$ pancreas. Values are enzyme activity expressed as mean units per milligram of DNA. Adapted from Lorenzo-Figueras et al. (2007).

\begin{tabular}{llllll}
\hline Species & Amylase & Lipase & $\begin{array}{l}\text { Elastase } \\
\text { U/mg of DNA }\end{array}$ & $\begin{array}{c}\text { Trypsin } \\
\text { Chymotrypsin }\end{array}$ \\
\hline Equine & 2.3 & 41.5 & 0.07 & 0.13 & 0.36 \\
Porcine & 107 & 49 & 0.22 & 0.44 & 2.26 \\
\hline
\end{tabular}

Pancreatic secretions contain large volumes of fluid and bicarbonate, allowing neutralization of digesta (Argenzio, 1990; Frape, 2004). Horses are continuous feeders and secretions from the pancreas are also continuous, measuring up to 10-12/L/day/100kg BW (Stevens and Hume, 1995; Alexander and Hickson, 1969). Bile buffers the $\mathrm{pH}$ in the small intestine to 7- 7.5 (Ellis and Hill, 2005; de Fombelle et al., 2003). 


\section{Microbial Fermentation}

While mammals do not secrete enzymes capable of breaking down complex structural carbohydrates, they are secreted by symbiotic microbes present in the host animal's digestive system (Frape, 2004). Structural carbohydrates are those not soluble in water-including cellulose, hemicellulose, and lignin-and are associated with the plant cell wall (Ellis and Hill, 2005). According to Frape (2004) there are three major distinctions between microbial fermentation (alloenzymatic digestion) and digestion by the host animal (autoenzymatic

digestion): (1) microflora in the intestine are capable of breaking down $\beta-1,4$ glycosidic bonds in carbohydrates, (2) intestinal microflora synthesize essential amino acids required by the host animal, and (3) intestinal microflora synthesize water-soluble vitamins required by the host animal.

The majority of microbial digesta fermentation occurs in the large intestine of the horse, producing volatile fatty acids (VFAs) and lactate (Frape, 2004). The majority of VFAs produced are acetate, propionate, and butyrate; these are quickly absorbed and utilized as energy sources (Pond et al., 2005). VFA metabolism in the cecum alone may account for about $30 \%$ of digestible energy intake (Glinsky et al., 1976). A pH of 6.5 is required for optimal microbial activity and VFA absorption by the horse (Frape, 2004). The $\mathrm{pH}$ of digesta in the large intestine cycles between 6.0 and 6.5 depending on concentrations of VFAs (Table 2) (Argenzio et al., 1974). A pH of less than 5.0 would damage colonic 
mucosa and shift the microbial population to favor lactate rather than VFA production (Argenzio, 1990; Alexander and Hickson, 1969).

Table 2. Measurements of cecal $\mathrm{pH}$ in the equine and diet fed.

Diet

Complete pelleted feed

Complete pelleted feed \&

straw

Complete pelleted feed \&

meadow hay
$\mathrm{pH}$
Reference

6.48

Glinsky et al., $1976(n=3)$

6.2

De Fombelle et al., 2003 $(n=3)$

6.4

De Fombelle et al., 2003 $(n=4)$

Digestion of complex carbohydrates prior to the hindgut of the horse is very low, however microbial populations that utilize starch and readily fermentable carbohydrates exist in high numbers in the saccus caecus region of the stomach and small intestine (de Fombelle, 2003; Argenzio, 1990; Ellis and Hill, 2005). Gastric microbial fermentation may be insignificant as an energy source but may provide the host with essential nutrients such as vitamin $B_{12}$ (Argenzio, 1990).

\section{Hindgut}

The hindgut of the horse consists of the cecum, colon, and rectum. Average $\mathrm{pH}$ range for various parts of the equine hindgut was 6.1-6.6 when measured during anesthesia (de Fombelle et al., 2003) (Table 2). The mammalian hindgut 
secretes no enzymes and is lined with columnar epithelium, containing mucussecreting goblet cells (Hume, 1997).

The cecum is a large blind sac located at the distal end of the ileum (Frape, 2004). Digesta entry into the cecum and out into the colon is controlled by separate valves (ileocaecal and caecoventral colonic) on the same end of the cecum and in close proximity to each other (Frape, 2004). Solid particles may reach the cecum within 60 minutes of ingestion; fluid within 30 minutes (Hintz, 1990). The cecum is about $1.25 \mathrm{~m}$ in length and has a capacity of $25-30$ liters total volume (Ellis and Hill, 2005). The cecum is the major site of water absorption in the equine digestive tract (Frape, 2004; Argenzio et al., 1974). The cecum and colon are responsible for approximately 30-40 percent of protein digestion and absorption, 25-35 percent of soluble carbohydrates, and 78-85 percent of fiber (Hintz, 1990).

The colon in the horse is about $10 \mathrm{~m}$ in length with a capacity of 50-60 liters (Ellis and Hill, 2005). The colon is divided into four parts (de Fombelle et al., 2003), the folding of which is important for controlling and limiting digesta flow and passage (Ellis and Hill, 2005).

Digesta must pass through four major barriers within the large intestine, the ileocaecal valve, the caecoventral colonic valve, the pelvic flexure, and the dorsal small colonic junction (Frape, 2004). Digesta passage rate depends on the 
increasing resistance met through each barrier and also on gut motility (Frape, 2004). Digesta passage rate through the equine digestive system also differs based on form of the diet, with pelleted feeds moving faster than chopped or long stem hay (Frape, 2004). The average mean retention time (MRT) for solid phase markers across a wide range of studies in the horse and pony is 42.3 hours (Ellis and Hill, 2005). Strong rhythmic and non-rhythmic contractions of the large intestine mix digesta and move it to the rectum (Frape, 2004). The rectum is 300 $\mathrm{mm}$ long and terminates at the anus (Frape, 2004).

The temperature in the hindgut of mammals is known to be relatively stable and close to body temperature (Hume, 1997). Using an ingestible sensor, Green et al. (2005) observed the average gastrointestinal tract temperature for horses over a 24 hour period was $38.0^{\circ} \mathrm{C}(\mathrm{n}=8)$. In contrast, the average rectal temperature for horses of both sexes was described as $37.7^{\circ} \mathrm{C}$ (Merck Veterinary Manual, 2010).

\section{In Vivo Digestibility Analysis}

Historically equine in vivo digestibility analysis and feed evaluation has been limited when compared to ruminants and other monogastric species (Ellis and Hill, 2005). Costs associated with feed, labor, and the number of animals required are high (Ellis and Hill, 2005). The difficulty of managing horses in

confined spaces has also been a concern. The following describes the basics of in vivo digestibility analysis. 
The basic in vivo procedure for determining digestibility of a feed by an animal is called a balance experiment (Schneider and Flatt, 1975). A balance experiment consists of measuring, by weight, the amounts consumed and amounts excreted over a period of several days (Schneider and Flatt, 1975). Multiple feed and fecal samples are taken during this time and their nutrient composition determined (Schneider and Flatt, 1975). The difference between the quantity of a nutrient consumed and the quantity excreted in the feces is expressed as a percentage of that nutrient in the feed and is reported as apparent digestibility (Schneider and Flatt, 1975). True digestibility represents only the portion of the nutrient absorbed from the gastrointestinal tract and the calculation excludes endogenous sources of the nutrient appearing in the feces (Pond et al., 2005).

Digestibility trials conducted to determine digestibility of feeds or nutrients for an animal usually contain three phases. In the first phase, animals are transitioned onto the test diet. The second phase is an acclimation phase of sufficient time (at least 7-10 d for horses) to ensure all components of the previous diet are removed from the digestive system and a uniform rate of passage is established (Schneider and Flatt, 1975). If the diet being studied is very different physically or chemically from the current diet, the acclimation phase should be increased to allow gastrointestinal microbial populations sufficient time to adapt (Schneider and Flatt, 1975). The final phase is a collection phase where intake and output is quantified for each animal (Schneider and Flatt, 1975). Intake must remain constant during the collection phase to avoid adding additional error to 
digestibility measurements (Schneider and Flatt, 1975; Pond et al., 2005). Total excreta output is collected using a metabolism crate or hygiene harness designed to collect feces and urine separately. During the collection phase, samples of feed and feces are taken and stored for proximate analysis.

Proximate analysis is described as calculating the percentages and amounts of water, proteins, carbohydrates, fats, minerals, and vitamins in a sample (Schneider and Flatt, 1975). Proximate analysis for equine digestibility trials focus mainly on carbohydrates because they are the principal energy source in equine diets (NRC, 2007).

Drying a sample is the first step in proximate analysis. Dry matter (DM) is defined as the non-water portion of a feedstuff, and its determination allows comparison between different feeds (Pond et al., 2005). Neutral detergent fiber (NDF) is comprised of the cell wall components; cellulose, hemicellulose, and lignin (Pond et al., 2005). Determining NDF digestibility is particularly useful when studying species that rely on microbial digestion because it divides soluble components susceptible to autoenzymatic digestion from those insoluble components available only to alloenzymatic digestion (Goering and Von Soest, 1970). Acid detergent fiber (ADF) is comprised of cellulose and lignin, its determination allows for an estimation of hemicellulose through deduction of NDF (Pond et al., 2005). Methods to determine ADF are used in preparation for lignin determination (Goering and Von Soest, 1970). Acid detergent lignin (ADL) is 
what remains after using sulfuric acid to remove cellulose from the sample (Goering and Von Soest, 1970). Organic matter (OM) of a sample can be determined after ashing the lignin residue; its reported digestibility would indicate digestion by both autoenzymatic and alloenzymatic processes.

\section{In Vitro Digestibility Analysis}

Starting with the original work of Tilley and Terry (1963) for use with the ruminant, in vitro digestibility methods have evolved and been successfully applied to swine, humans, and several other monogastric species. These methods attempt to predict the in vivo behavior of one or more nutrients using a single or multiple step procedure.

The most common method for studying digestion and fermentation of multiple nutrients in vitro is the three stage batch method. The three stage batch method is a closed system that models the three major phases of digestion in a monogastric hindgut fermenter: the first two are autoenzymatic and include the stomach and small intestine, the third is alloenzymatic and includes the hindgut. Because there is no continuous input or output a batch system is considered simpler and easier to replicate than a continuous system, which is typically used for studying microbial ecology of the large intestine (Coles et al., 2005).

Boisen and Fernandez (1997) described a three stage batch system for assessing the digestibility of swine feeds; a strong correlation was observed 
between in vivo and in vitro digestibility for 31 commonly used ingredients. The Danish Agricultural Advisory Centre has officially adopted a method based on the prediction equation of Boisen and Fernandez (1997) for assessing the energy content of complete feeds for swine. This equation estimates the digestible energy (DE) of individual ingredients and can be used to control DE variability between diets (Boisen and Fernandez, 1997). Further discussion of in vitro batch systems will focus in general on the original methods described by Boisen and Fernandez (1997) with slight modifications. However, quoted studies may have used alternative in vitro methods.

In preparation for the first stage of a batch system, a sample is ground to a consistent particle size using a Wiley mill $(1 \mathrm{~mm})$ and placed in a test tube or flask. Less reproducible results were obtained with a larger particle size $(3 \mathrm{~mm})$ and in vitro digestibility was reduced (Boisen and Fernandez, 1997). The initial samples should be consistent in weight and no less than $0.5 \mathrm{~g}$ (Boisen and Eggum, 1991; Damiran et al., 2008).

An $\mathrm{HCl}$ and pepsin solution is then added, modeling the stomach and initiating protein digestion (the digestive activity of saliva is not modeled in the three stage batch system). To prevent bacterial growth, especially during the second stage, a chloramphenicol solution is added to each tube (Boisen and Fernandez, 1991). The $\mathrm{pH}$ in the tube is 2.0. The tubes or flasks are placed in a water bath or incubator, kept at a consistent temperature, and subject to continuous or 
intermittent stirring for 6 hours. In the equine, a significant portion of digesta may remain in the stomach for up to 6 hours (Frape, 2004).

Digestive action in the small intestine is mainly a function of endogenous enzymes; in the corresponding second stage in the batch system, a porcine pancreatin solution is added after increasing the $\mathrm{pH}$ in the tubes or flasks to 6.8 using a sodium hydroxide solution. Each mg of pancreatin contains 25 USP units of amylase activity, 2.0 USP units lipase activity, and 25 USP units protease activity (The United States Pharmacopeia, 2007). Many in vitro methods for studying digestibility are based on consecutive incubations with pepsin and pancreatin, suggesting that pancreatin contains all the necessary enzymes for solubilizing the potentially digestible nutrients (Boisen and Eggum, 1991). Pancreatin has three major benefits over intestinal fluid: it is commercially available, consistent in composition, and contains no microbial enzymes. After addition of the pancreatin solution the tubes or flasks are subject to the same incubation conditions as in stage one, for $18 \mathrm{~h}$, before the beginning of stage 3 .

Although purified enzymes are able to simulate digestion (Boisen and Fernandez, 1997), microbial enzymes are needed to ferment substrates during the third stage of the procedure (Boisen and Eggum, 1991). Feces are typically used as a microbial inoculumn source because it is easy to obtain and requires no invasive techniques (Lowman et al., 1999). Microflora have been shown to remain viable for several hours after excretion from the digestive tract (Holter, 
1991), although increased time from excretion must reduce the inoculumn quality (Vince et al., 1976). Recent data have validated the use of feces as a source of inoculum for in vitro studies (Lattimer et al., 2007). Because equines are hindgut fermenters, their feces should provide a viable source of microorganisms (Lowman et al., 1999). Lowgren et al. (1989) observed similar results when comparing in vitro dry matter disappearance using microbial inoculumn from porcine feces compared to inoculumn from ileal or duodenal origin, suggesting either could be used. Lowman et al. (1999) observed typical gas production profiles when using inoculumn from equine feces to ferment multiple equine feedstuffs in vitro. Furthermore, Macheboeuf et al. (1998) observed similar gas production profiles using equine feces compared to equine caecal contents when fermenting 52 forages in vitro.

When using human feces as inoculumn for determining in vitro fermentability, Edwards et al. (1996) observed studies having only four subjects showed the most variability. Because fermentations were performed on individual fecal samples, the results represent biological variation and experimental error (Edwards et al., 1996). But when fecal samples from donors are combined to prepare fecal inoculumn, the biological variation is removed, and less than five donors may be adequate. In a more recent study, Murray et al. (2003) observed fermentative capacity of fecal inoculumn from individual ponies fed the same diet did not differ significantly $(n=7)$, suggesting a small number of animals may be adequate when using fecal inoculumn prepared from horses. 
Additionally, because microbial profiles in the large intestine change with diet (Julliand et al., 2001; Kern et al., 1973; Frape, 2004); it may be necessary to adapt inoculumn donors to the diet being studied in vitro. Murray et al. (2003) observed adapting donor ponies had an effect on dry matter disappearance in vitro, although this study was not validated with in vivo digestibility. In two human studies, Barry et al. (1995) and Daniel et al. (1997), there was no influence on in vitro fermentation when test subjects were adapted to the fiber being tested $(n=$ $2, n=6$, respectively).

Over $90 \%$ of living bacteria in feces are obligatory anaerobes (Vince et al., 1976), therefore feces should be collected and transported in an anaerobic manner (to maintain viability) as described by Lattimer et al. (2007). Feces are then diluted with an anaerobic solution and strained, resulting in a liquid fecal inoculumn that must be kept anaerobic and used immediately. Using bacterial culture, Vince et al. (1976) observed if feces were diluted to $25 \%$ with a saline solution total cell counts and viable cell counts remained unaltered over a 48-hour incubation; however, if feces were diluted to $33 \%$ or remained undiluted, significant changes occurred after 24 hours. Microbial death must be taken into account when determining incubation times during the final stage of the in vitro batch system.

Typical incubation time for the third stage of a batch in vitro system modeling hindgut digestion is $24 \mathrm{~h}$ (Coles et al., 2005). Several studies suggest longer incubation times may be necessary when studying equine in vitro digestibility. 
Löwgren et al. (1989) suggested a combination of short and long incubation times to simulate in vivo digestion in swine. Results from the short incubation time representing readily digestible nutrients and the difference between long and short incubation times representing the fermented components. In a recent equine study, Ringler et al. (2005) observed no significant difference between in vivo and in vitro dry matter digestibility for three out of four feeds tested when using a $72 \mathrm{~h}$ incubation time. In another study, significantly lower substrate fermentation occurred at 6,12 and $24 \mathrm{~h}$ incubation when using fecal inoculumn from horses compared to that from other species (e.g. swine, human, feline, canine), after $48 \mathrm{~h}$ the observed differences began to disappear (Sunvold et al., 1995). The longer incubation time necessary to ferment substrates using microflora from equine feces may be due to a lower bacterial count per gram than other species (Sunvold et al., 1995).

Because each species is physiologically unique, it is necessary to match variables in the in vitro method to in vivo conditions and events for that species. Temperature, $\mathrm{pH}$, incubation time, and degree of mixing should be simulated for in vivo traits of the species in question (Coles et al., 2005).

The degree of fermentation of a substrate is measured in terms of nutrient disappearance (Coles et al., 2005). The proportion of a nutrient that "disappears" in the animal and is not excreted is assumed to be digestible, defining its digestibility (Ellis and Hill, 2005). Dry matter and organic matter disappearance 
are commonly reported for in vitro studies (Coles et al., 2005), and are based on measurements of unsolubilized material collected during filtration following the fermentation stage. In a study utilizing only the third stage and equine fecal inoculumn, Lowman et al. (1999) observed samples agglutinating during the incubation process could lead to poor filtration and highly variable results. Additionally, Lowman et al. (1999) observed the determination of dry matter disappearance as a single predictor gave poor estimates of in vivo digestibility.

In vitro methods are typically designed to measure maximum digestibility by providing ideal conditions for fermentation. In vitro digestibility values are expected to be higher than in vivo values, as seen by Boisen and Fernandez (1991) and Daniel et al. (1997). Because in vitro digestibility cannot account for endogenous proteins and other components contributing to the value of apparent digestibility in vivo, in vitro measurements may be closer to true digestibility. 


\section{Objective}

\section{IN VIVO EVALUATION}

Evaluate two pelleted complete feeds for digestibility and availability of selected nutrients to establish validation points for development of an in vitro digestibility assay.

\section{Methods}

\section{Study Design}

In vivo evaluation of the treatment diets for in vitro comparison was performed in conjunction with a larger evaluation. Ten American quarter horse geldings between 4.5 and 16 years of age were used in the in vivo evaluation. The evaluation consisted of two phases in a randomized crossover design. Nutrient composition of the pelleted complete feeds is provided in Table 3. Phase 1 consisted of $7 \mathrm{~d}$ pretransition, $14 \mathrm{~d}$ transition, $28 \mathrm{~d}$ acclimation, and $15 \mathrm{~d}$ collection (Table 4). There were $48 \mathrm{~d}$ between phase 1 and 2 (Table 4). Phase 2 consisted of $7 \mathrm{~d}$ transition, $28 \mathrm{~d}$ acclimation, and $15 \mathrm{~d}$ collection (Table 4). 
Table 3. Select nutrient composition of the experimental diets, on a dry matter basis (DMB) except dry matter (DM) ${ }^{1}$.

\begin{tabular}{lcc}
\hline Component & Control & Test \\
\hline$\% \mathrm{DM}^{2}$ & 91.7 & 91.9 \\
$\% \mathrm{NDF}^{2}$ & 45.6 & 45.8 \\
$\% \mathrm{ADF}^{2}$ & 29.7 & 28.4 \\
$\% \mathrm{ADL}_{\mathrm{OM}}{ }^{2}$ & 1.1 & 1.1 \\
$\% \mathrm{OM}^{2}$ & 98.9 & 98.9 \\
$\% \mathrm{CP}^{3}$ & 12.7 & 13.1 \\
$\mathrm{McalDE}^{\mathrm{kg}}$ (calc. $)^{3}$ & 2.27 & 2.33 \\
$\% \mathrm{Ca}^{3}$ & 1.2 & 1.1 \\
$\% \mathrm{P}^{3}$ & 0.4 & 0.4 \\
$\mathrm{ppm} \mathrm{Cu}^{3}$ & 40.5 & 37.0 \\
$\mathrm{ppm} \mathrm{Se}^{3}$ & 2.2 & 1.4 \\
$\mathrm{ppm} \mathrm{Zn}$ & 124.3 & 167.7 \\
\hline
\end{tabular}

${ }^{\top}$ Abbreviations: $\mathrm{DM}=$ dry matter, NDF = neutral detergent fiber, $\mathrm{ADF}=$ acid detergent fiber, $A D L_{O M}=$ acid detergent lignin on an organic matter basis, $O M=$ organic matter, $\mathrm{CP}=$ crude protein, $\mathrm{Mcal}=$ mega calorie, $\mathrm{DE}=$ digestible energy. ${ }^{2}$ Analysis completed at California Polytechnic State University.

${ }^{3}$ Analysis provided by Dairy One Forage Laboratory (Ithaca, New York). 
Table 4. Phases of the in vivo diet evaluation detailing stages within each phase and objective and duration for each.

\begin{tabular}{llr}
\hline Phase 1 & Objective & Duration (d) \\
\hline Pretransition & $\begin{array}{l}\text { Transition from 50:50 alfalfa hay:bermuda } \\
\text { hay to 100\% bermuda hay }\end{array}$ & 7 \\
Transition & $\begin{array}{l}\text { Transition from 100\% bermuda hay to 100\% } \\
\text { pelleted diet }\end{array}$ & 14 \\
Acclimation & Allow animal to respond to dietary treatment & 28 \\
Collection & Quantify food intake, and fecal output & 15 \\
Washout & Remove control and treatment diet from all & 48 \\
\hline Phase 2 & Subjects & Objective \\
\hline Transition & Transition from washout diet to test diets & 7 \\
Acclimation & Allow animal to respond to dietary treatment & 28 \\
Collection & Quantify food intake, and fecal output & 15 \\
\hline
\end{tabular}

\section{Diet Transition}

During phase 1 horses were transitioned from 50\% Bermuda grass (Cynodon dactylon):50\% alfalfa hay (Medicago sativa), to 100\% Bermuda grass hay over a period of $7 \mathrm{~d}$ while group housed in a dry lot pasture. Horses were then transferred to individual galvanized metal pipe stalls, consisting of a covered area with rubber floor mats $(3.66 \times 3.66 \mathrm{~m})$, and outside run with compacted decomposed granite $(3.66 \times 7.32 \mathrm{~m})$. No bedding was used in the stalls. Horses on like treatments were grouped in adjacent stalls with an empty stall between groups. Horses were randomly assigned to either the test or control diet, then 
randomly assigned to stall order within each group. Horses were transitioned gradually from Bermuda grass hay to the $100 \%$ pelleted treatment diets over a period of $14 \mathrm{~d}$. The ingredients of the two treatments were similar: wheat middlings, rice hulls, alfalfa and beet pulp. The test diet differed in added mineral sources, yeast, direct fed microbials, and Yucca schidigera extract, added to enhance dry matter digestibility of the test diet. Following phase 1 collection horses were fed a control pellet (washout) for $48 \mathrm{~d}$. Transition from the washout diet to the opposite treatment diet occurred over $7 \mathrm{~d}$.

\section{Feeding}

Each treatment was fed as $100 \%$ of the animal's daily intake. Horses were weighed prior to acclimation (initial BW) and weekly throughout both phases of the evaluation. Total daily intake was offered at $2.0 \%$ of initial body weight (BW), dry matter (DM) basis, and amount offered was not adjusted within each phase. Feed was weighed to the nearest $10 \mathrm{~g}$ using a digital scale (Rice Lake Weighing Systems, Rice Lake, WI). Horses were fed twice daily (0700 h, 1700 h) in two equal portions, and orts collected prior to each feeding throughout the evaluation. Pellets and hay were both offered in a $265 \mathrm{~L}$ stock tank situated in the corner of each covered stall, opposite the ad libitum water source.

\section{Animal Care}

Horses received vaccinations for West Nile virus (West Nile- Innovator ${ }^{\circledR}$; Fort Dodge ${ }^{\circledR}$ Animal Health, Fort Dodge IA) and Encephalomyelitis-Influenza vaccine 
(Fluvac Innovator ${ }^{\circledR}$ 4; Fort Dodge Animal Health, Fort Dodge, IA). All horses were treated with Quest ${ }^{\circledR}$ Gel (Moxidectin; Fort Dodge Animal Health, Fort Dodge IA) at least $7 \mathrm{~d}$ before diet acclimation. Oral health of all animals was screened for abnormalities and documented by a licensed equine veterinarian. Dental treatment, including floating was accomplished at least $7 \mathrm{~d}$ before diet acclimation by a licensed equine veterinarian as required. Horses were handwalked 30 minutes per day while housed in stalls and groomed daily. Horses were allowed visual, olfactory, and auditory contact with other horses, and limited tactile contact with other horses on the same diet treatment. Stalls were cleaned at least once daily, and stall mats swept to improve accuracy of orts collection. Horses were allowed ad libitum access to water by automated float style waterers in each stall. Ad libitum access to a $4 \mathrm{lb}(1,814.4 \mathrm{~g})$ plain salt $(\mathrm{NaCl})$ brick was also allowed. Horses were weighed on a weekly basis and body condition score was frequently calculated (Henneke et al., 1983). Use of the animals indicated in this study, protocol \#807, has been reviewed and approved by the California Polytechnic State University Institutional Animal Care and Use Committee. Animal care was the same for both phases.

\section{Collection}

All horses were acclimated to and fitted with a equine hygiene harnesses (Equisan Marketing, Ltd., South Melbourne, Victoria, Australia) prior to the start of the trials to allow for total collection of uncontaminated feces. Harnesses were numbered and assigned to individuals throughout each phase. Harnesses were 
kept within diet treatment throughout the trial and reassigned to another individual at the beginning of phase 2. Harnesses were weighed before the start of each collection period to establish a tare weight. Harnesses were placed on individual horses at $1900 \mathrm{~h}$ the evening before the first collection day. Feces

were collected twice daily $(0700 \mathrm{~h}, 1500 \mathrm{~h})$. Collected feces were emptied into 5 gallon buckets and feces weighed to the nearest $10 \mathrm{~g}$ using a digital scale (IQ+390-DC Indicator, HD3030-100 Floor Scale, Rice Lake Weighing Systems, Rice Lake, WI). After initial emptying and before washing, the harness was weighed to the nearest $10 \mathrm{~g}$ using a digital scale (IQ+390-DC Indicator, HD3030100 Floor Scale, Rice Lake Weighing Systems, Rice Lake, WI) to account for any residual fecal content. Harness were thoroughly washed after each collection. A 500-2000 g sample was collected daily into re-sealable plastic bags during the $0700 \mathrm{~h}$ collection. Samples were frozen at $-20^{\circ} \mathrm{C}$ within 12 hours. A collection day was measured in $24 \mathrm{~h}$ (0700- 0700h the following day) for 15 total collection days. Daily total intake as-fed and excretion fresh weight basis were calculated for each individual on each collection day. Horses were fed according to the above methods. Intake was not quantified on day 16 however a fecal sample was collected at 0700 . Collection was the same for both phases.

\section{Feed Sampling}

Each diet was sampled on $\mathrm{d} 1,8$, and 15 of collection during each phase using a dedicated trier (No. 76, Seedburo Equipment Co., Des Plains, IL). 


\section{Oven Dry Matter (DM)}

Frozen samples were dried in aluminum pans to constant weight to the nearest 1 g (SB32001 Delta Range, Mettler Toledo, Columbus, $\mathrm{OH}$ ) at $50^{\circ} \mathrm{C}$ in a forced air oven (DNK600, Yamato Scientific America Inc., Santa Clara, CA). The following equation was used to calculate \% Oven DM:

$$
\left(\frac{\text { Final Weight }}{\text { FreshWeight }}\right) \times 100=\% \text { Oven DM }
$$

\section{Sample Grinding}

Fecal samples were hand crushed following drying. A $25 \mathrm{~g}$ subsample was taken from the larger dry fecal samples. A $25 \mathrm{~g}$ subsample was also taken from each feed sample. All $25 \mathrm{~g}$ subsamples were ground through a 10-mesh (2mm) screen using a Thomas Wiley Mini-Mill (Thomas Scientific, Swedesboro, NJ).

\section{Lab (Final) Dry Matter (DM)}

Lab DM \% of individual fecal and feed samples was calculated in duplicate, using the cold weigh method with the $2 \mathrm{~mm}$ ground sample and $1 \mathrm{oz}$ aluminum tins with lids (NFTA, 1993) (Appendix Y). Weights were calculated to the nearest $0.0001 \mathrm{~g}$ using a digital scale (XS205, Mettler Toledo, Columbus, OH). The following equation was used to calculate \% Lab DM:

$$
\left(\frac{\text { Final Weight }}{\text { Fresh Weight }}\right) \times 100=\% \text { Lab DM }
$$




\section{Fiber Analysis}

Fiber analysis was performed in duplicate on fecal samples from $d 1,8$, and 16 of collection for each individual and feed samples using the $2 \mathrm{~mm}$ ground sample. Neutral detergent fiber (NDF), and acid detergent fiber (ADF) were determined using the filter bag technique (Neutral/Acid Detergent Fiber in Feeds Filter Bag Technique, ANKOM $\left.{ }^{200}, 10 / 21 / 05\right)$ with the $\mathrm{ANKOM}^{200}$ fiber analyzer (ANKOM Technology, Macedon, NY). Acid detergent lignin (ADL) was determined using the Method for Determining Acid Detergent Lignin in Beakers (ANKOM Technology, 8/05) however ADL is not reported. Fiber bags and $2 \mathrm{~mm}$ ground sample from all collection days were ashed in a muffle furnace (M-525 Series II, DENTSPLY Neytech ${ }^{\text {TM }}$ Equipment, York, PA) to determine acid detergent lignin organic matter (ADL ${ }_{\text {om }}$ ) and organic matter (OM) respectively (NFTA, 1993) (Appendix Z). All weights relating to fiber analysis were measured to the nearest $0.0001 \mathrm{~g}$ using a digital scale (XS205, Mettler Toledo, Columbus, OH) The following equations were used to calculate \% NDF (DM), \% ADF (DM), \% ADL (DM), and \% OM (DM):

$$
\begin{aligned}
& \% N D F(D M)=\frac{\left(W_{3}-\left(W_{1} \times C_{1}\right)\right)}{\left(W_{2} \times \% \text { Lab } D M\right)} \times 100 \\
& \% A D F(D M)=\frac{\left(W_{3}-\left(W_{1} \times C_{1}\right)\right)}{\left(W_{2} \times \% \text { Lab DM }\right)} \times 100 \\
& \% A D L_{o m}(D M)=\frac{\left(\left(W_{4}-\left(W_{1} \times C_{2}\right)\right) \times 100\right)}{\left(W_{2} \times \% \text { Lab } D M\right)}
\end{aligned}
$$


$\% O M(D M)=100-\frac{\left(\left(W_{3}-W_{1}\right) \times 100\right)}{\left(W_{2} \times \% \text { Lab DM }\right)}$

$\mathrm{W}_{1}=$ Empty bag or crucible weight

$\mathrm{W}_{2}=$ Sample weight

$\mathrm{W}_{3}=$ Final dry weight of fiber bag or crucible containing sample residue

$\mathrm{W}_{4}=$ Weight of organic matter (OM)

$\mathrm{C}_{1}=$ Blank bag correction (final oven dry-weight/original blank bag weight)

$\mathrm{C}_{2}=$ Ash corrected blank bag (Loss of weight on ignition of bag/original blank bag)

Measurements of \% NDF (DM), \% ADF (DM), \% ADL om (DM), and \% OM (DM)

for $\mathrm{d}$ 1, 8, 16 were averaged across individual animal on each diet (not reported)

and each feed within each phase (Table 3).

Table (5) Mean ( \pm SD) composition of the experimental diets, on a dry matter basis (DMB) except dry matter (DM). ${ }^{1}$

\begin{tabular}{lrr}
\hline Component $^{2}$ & Control & Test \\
\hline Phase 1 & & \\
\% DM & $91.83 \pm 0.09$ & $91.32 \pm 0.42$ \\
\% NDF & $44.38 \pm 1.08$ & $45.43 \pm 1.28$ \\
\% ADF & $28.38 \pm 0.94$ & $28.64 \pm 0.94$ \\
\% ADL OM & $1.08 \pm 0.01$ & $1.08 \pm 0.01$ \\
\% OM & $98.92 \pm 0.01$ & $98.92 \pm 0.01$ \\
& & \\
Phase 2 & & $91.91 \pm 0.24$ \\
\% DM & $91.90 \pm 0.22$ & $45.00 \pm 1.00$ \\
\% NDF & $45.05 \pm 0.70$ & $28.63 \pm 0.36$ \\
\% ADF & $29.01 \pm 0.88$ & $1.07 \pm 0.00$ \\
\% ADL OM & $1.08 \pm 0.00$ & $98.93 \pm 0.00$ \\
\hline OM & $98.92 \pm 0.00$ &
\end{tabular}

${ }^{1}$ Samples were analyzed by diet and by period and then averaged $(n=4$ for both diets in phase $1, \mathrm{n}=2$ for both diets in phase 2).

${ }^{2}$ Abbreviations: $\mathrm{DM}=$ dry matter, NDF = neutral detergent fiber, $A D F=$ acid detergent fiber, $A D L_{O M}=$ acid detergent lignin on an organic matter basis, $\mathrm{OM}=$ organic matter 


\section{Digestibility Calculations}

Total daily dry matter intake (DMI) and daily dry matter excretion (DME) for d 115 of collection for each individual were calculated using the following equations:

$$
\begin{gathered}
D M I=(\text { Total intake as }-f e d(\% \text { Lab DM })) \\
D M E=((\text { Total feces wet weight }(\% \text { Oven DM })) \% \text { Lab DM })
\end{gathered}
$$

Apparent digestibility (aDig) of \% DM, \% NDF, \% ADF, \% ADL (DM) were calculated by summing daily DMI and DME for each individual over days $1-15$ of collection and using the following equations:

$\% A D i g D M=\frac{D M I-D M E}{D M I} \times 100$

$\% A D i g N D F=\frac{D M I(\% N D F D M)-D M E(\% N D F D M)}{D M I(\% N D F D M)}$

$\%$ ADig $A D F=\frac{D M I(\% A D F D M)-D M E(\% A D F D M)}{D M I(\% A D F D M)}$

$\%$ ADig ADL OM $=\frac{D M I(\% A D L O M D M)-D M E(\% A D L O M D M)}{D M I(\% A D L O M D M)}$

$\% A D i g O M=\frac{D M I(\% O M D M)-D M E(\% O M D M)}{D M I(\% O M D M)}$ 


\section{Statistical Analysis}

When the equine hygiene harness was unsuccessful in collecting total fecal output for any 24 hour collection day due to equipment failure or removal by the individual horse, daily DMI and DME were calculated separately for the categories successful (Yes) or unsuccessful (No).

BW used in calculations and statistics was an average of the three weights observed for each individual during each collection phase.

Data was analyzed using the GLM procedure (Minitab 16, Minitab Inc., State College, PA). The model statement tested for the effects of diet, horse, harness success (on or off) and phase, with horse as a random effect. "Harness on" refers to the hygiene harness being successful in collecting total fecal output for a $24 \mathrm{~h}$ period, and "harness off" refers to the hygiene harness being unsuccessful in collecting total fecal output for a $24 \mathrm{~h}$ period. Data were first analyzed to determine the effect of harness success on aDig ${ }_{\mathrm{DM}}$.

Harness success variable was then removed from the model and the data were reanalyzed. If the equine hygiene harness was unsuccessful in collecting total fecal output for any $24 \mathrm{~h}$ period due to equipment failure or removal by the individual horse these data were excluded from analysis and daily DMI and DME sums were recalculated. Separate tests were run for aDig ${ }_{D M}, N D F, A D L_{O M}$, and $\mathrm{OM}$, and intake and fecal excretion of each expressed as a percentage of BW. 


\section{$\underline{\text { Results }}$}

\section{Apparent Digestibility}

When harness success values of "Off" were included in the analysis, there was a trend for aDig ${ }_{D M}$ to differ between the two experimental diets $(P=0.080)(T a b l e$ 6). aDig ${ }_{D M}$ was significantly different between harness success values of "Off" and "On" $(P<0.000)$ with aDig ${ }_{D M}$ being higher for "Off" values (Table 7). When harness "Off" values were removed and data were reanalyzed the observed differences in $\mathrm{aDig}_{\mathrm{DM}}$ between the two experimental diets were not detected $(P=$ 0.532) (Table 8). No differences were seen in aDig of NDF, ADF, ADLom or OM between the two experimental diets $(P=0.264,0.382,0.714$, and 0.623$)$ (Table 8). 
Table 6. Mean \% aDig DM $( \pm$ SD) of the experimental diets. $(n=17)$ for each diet. Includes harness success values of Off. ${ }^{1}$

\begin{tabular}{llll}
\hline & Control & Test & $P$-value \\
\hline DM & $58.13 \pm 6.00$ & $61.81 \pm 9.13$ & 0.080 \\
\end{tabular}

${ }^{1}$ Abbreviations: $\mathrm{aDig} \mathrm{DM}_{\mathrm{DM}}=$ apparent digestibility on a dry matter basis, $\mathrm{DM}=$ dry matter.

Table 7. Mean \% aDig ${ }_{\mathrm{DM}}( \pm \mathrm{SD})$ by harness success, of the experimental diets. ${ }^{1}$

\begin{tabular}{llll}
\hline & On $(n=20)$ & Off $(n=14)$ & $P$-value \\
\hline DM & $55.25 \pm 4.23$ & $66.71 \pm 6.81$ & $<0.000$
\end{tabular}

${ }^{1}$ Abbreviations: $\mathrm{aDig} \mathrm{DM}_{\mathrm{DM}}=$ apparent digestibility on a dry matter basis, $\mathrm{DM}=\mathrm{dry}$ matter.

Table 8. Mean \% aDig ( \pm SD) of DM, NDF, ADL diets. $\mathrm{n}=10$ for each diet. Includes harness success values of On only.

\begin{tabular}{llll}
\hline Component $^{1}$ & Control & Test & $P$-value \\
\hline DM & $54.57 \pm 1.10$ & $55.93 \pm 5.96$ & 0.532 \\
OM & $63.40 \pm 1.18$ & $64.23 \pm 4.73$ & 0.623 \\
NDF & $30.58 \pm 1.70$ & $34.37 \pm 8.63$ & 0.264 \\
ADF & $24.30 \pm 2.14$ & $27.60 \pm 9.67$ & 0.382 \\
ADL & $56.66 \pm 1.15$ & $57.41 \pm 5.77$ & 0.714 \\
\hline
\end{tabular}

${ }^{1}$ Abbreviations: $\mathrm{aDig}=$ apparent digestibility, $\mathrm{DM}=$ dry matter, NDF $=$ neutral detergent fiber, $A D F=$ acid detergent fiber, $A D L_{O M}=$ acid detergent lignin on an organic matter basis, $\mathrm{OM}=$ organic matter.

\section{Dry Matter Intake and Dry Matter Excretion}

There was no difference in DMI or DME, as a percentage of body weight, between the two experimental diets (Table 9). 
Table 9. Mean DMI ( \pm SD) and DME ( \pm SD) as a percentage of BW of DM, NDF, $A D L_{O M}$, and OM, of horses consuming the experimental diets. $n=10$ for each diet. Includes harness success values of On only.

\begin{tabular}{cccc}
\hline Component $^{1}$ & Control & \multicolumn{2}{c}{$P$-value } \\
\hline DM & & & \\
DMI & $1.96 \pm 0.12$ & $1.93 \pm 0.15$ & 0.610 \\
DME & $0.89 \pm 0.07$ & $0.85 \pm 0.13$ & 0.450 \\
OM & & & \\
DMI & $1.94 \pm 0.12$ & $1.91 \pm 0.15$ & 0.611 \\
DME & $0.71 \pm 0.05$ & $0.68 \pm 0.10$ & 0.507 \\
NDF & $0.88 \pm 0.06$ & $0.88 \pm 0.07$ & 0.961 \\
DMl & $0.61 \pm 0.05$ & $0.57 \pm 0.09$ & 0.323 \\
DME & & & \\
ADF & $0.56 \pm 0.04$ & $0.55 \pm 0.04$ & 0.552 \\
DMI & $0.43 \pm 0.03$ & $0.40 \pm 0.06$ & 0.323 \\
DME & & & \\
ADLOM & $0.02 \pm 0.00$ & $0.02 \pm 0.00$ & 0.490 \\
DMI & $0.01 \pm 0.00$ & $0.01 \pm 0.00$ & 0.534 \\
DME &
\end{tabular}

${ }^{1}$ Abbreviations: $\mathrm{DMI}=$ dry matter intake, $\mathrm{DME}=$ dry matter excretion, $\mathrm{BW}=$ body weight, $\mathrm{DM}=$ dry matter, NDF = neutral detergent fiber, $\mathrm{ADF}=$ acid detergent fiber, $A D L_{O M}=$ acid detergent lignin on an organic matter basis, $\mathrm{OM}=$ organic matter.

The effect of phase was not significant $(P>0.05)$ for all tests run on aDig, DMl, and DME.

\section{Body Weight}

BW was not significantly different $(P>0.05)$ between diets, however there was a trend for heavier BW during phase $2(P=0.073)$. 
Table 10. Average BW $(\mathrm{kg})( \pm \mathrm{SD})$ of horses consuming the experimental diets $(\mathrm{n}$ $=10$ for each diet). ${ }^{1}$

\begin{tabular}{llll}
\hline & Control & Test & $P$-value \\
\hline BW & $562.4 \pm 42.3$ & $552.5 \pm 48.1$ & 0.151 \\
\hline
\end{tabular}

${ }^{1}$ Abbreviations: $\mathrm{BW}=$ body weight.

Table 11. Average BW $(\mathrm{kg})( \pm \mathrm{SD}$ ) of horses consuming the experimental diets during each phase ( $\mathrm{n}=10$ for each phase). ${ }^{1}$

\begin{tabular}{llll}
\hline & 1 & 2 & $P$-value \\
\hline BW & $551.0 \pm 49.8$ & $563.9 \pm 39.9$ & 0.073 \\
\hline
\end{tabular}

Abbreviations: BW = body weight. 


\section{Discussion}

Horses regularly left orts and intake was not at a constant rate for some horses during collection. Because a change in intake would not immediately reflect a change in excretion, error was introduced during the collection period (Schneider and Flatt, 1975). Along with this error, digestibility coefficients, when calculated on a daily basis, were often negative due to the variable intake. To solve these complications, sums were taken of DMI and DME over the 15 day period and one digestibility coefficient was calculated for each animal on each diet for each nutrient. Because the test diets were homogenous in composition, the proportions of nutrients in the feces were also assumed to be homogenous as animals could not refuse certain portions of the diet.

Hintz (1990) observed higher digestibility of DM and NDF when feeding a complete pelleted feed, (also offered two times per day), than the current study (Table 12). Digestibility of ADF observed by Hintz (1990) was slightly higher than that observed for the Control diet in the current study and exactly the same for the Test diet (Table 12). No additional information is available from Hintz (1990) on diet composition or methods of evaluation. The effects of grain processing and type in processed feeds will effect variation between digestibility trials and could explain some of the significant variation seen between these two studies (NRC, 2007). 
Table 12. Comparisons of aDig (DM basis) of pelleted feeds for DM, NDF, and ADF between studies ${ }^{1}$.

\begin{tabular}{llllll}
\hline & Diet & DM & OM & NDF & ADF \\
\hline Hintz, 1990 & Complete pelleted & 71.0 & - & 44.6 & 27.6 \\
Drogoul et. & Lucerne/Cocksfoot & 53.8 & 55.2 & 47.0 & 39.6 \\
al. , 2000 & hay- pelleted & & & & \\
Current & Control & 54.6 & 63.4 & 30.6 & 24.3 \\
Study & Test & 56.0 & 64.2 & 34.4 & 27.6 \\
\hline
\end{tabular}

${ }^{1}$ Abbreviations: aDig = apparent digestibility, $\mathrm{DM}=$ dry matter, $\mathrm{OM}=$ organic matter, NDF = neutral detergent fiber, $\mathrm{ADF}=$ acid detergent fiber.

The level of DM intake also may significantly affect observations of total tract digestibility between studies (NRC, 2007). Because the digestible energy (DE) concentration of the Test and Control diets were not known prior to starting the evaluation, horses were fed at $2 \%$ of their body weight, on a DM basis. The NRC (2007) recommends an average $500 \mathrm{~kg}$ horse with a sedentary lifestyle be fed 15.2 DE Mcal/day. The DE concentration of the Control diet is $2.27 \mathrm{DE} / \mathrm{Mcal} / \mathrm{kg}$, a $500 \mathrm{~kg}$ horse in the current study would have received $10 \mathrm{~kg}$ Control feed/day for a total of $22.7 \mathrm{DE} / \mathrm{Mcal} /$ day, almost $50 \%$ more than is recommended by the NRC.

Differences between sample sizes for the harness "On" and "Off" average \% aDig ${ }_{D M}$ analysis resulted because one horse had no observations on either diet of harness "Off" and 4 others had no observations of harness "Off" on one of the diets (Table 7). The sample size for average \% aDig ${ }_{D M}$ was 17 for each diet (Table 6) because 3 horses had no observations of harness "Off" for each of the experimental diets. However, hygiene harnesses were often extremely heavy, and fecal loss occurred due to snaps breaking under the weight, when emptied 
twice per day. The harness success analysis was therefore required to make accurate comparisons between the two experimental diets. It is recommended future studies empty hygiene harnesses at least three times daily to reduce fecal loss and improve study accuracy. Loss can also be prevented by monitoring horses $24 \mathrm{~h}$ per day during trials to correct hygiene harness problems sooner and by keeping an empty stall or other barrier between horses as animals were often observed pulling on each other's harness straps. 


\section{IN VITRO EVALUATION}

\section{Objectives}

Research proper techniques, reagents, and equipment. Obtain consistent results with method (as-is). Create a detailed manual for future users. Compare results to in vivo values. Recommend changes for increased consistency. Recommend changes for adaptation to horses.

\section{Methods}

\section{Stage 1}

Feed samples from the Control feed used in the in vivo evaluation were ground through a $(1 \mathrm{~mm})$ screen using a Thomas Wiley Mini-Mill (Thomas Scientific, Swedesboro, NJ). Ground sample $(0.5 \mathrm{~g})$, was weighed to the nearest $0.0001 \mathrm{~g}$ using a digital scale (XS205, Mettler Toledo, Columbus, $\mathrm{OH}$ ), in $50 \mathrm{ml}$ round centrifuge tubes (PPCO, Thermo Scientific, Rochester, NY). Tubes were prepared in 4 sets of 8 , each set containing 3 blanks. Phosphate buffer $(12.5 \mathrm{ml})$, composition (g/L): $\mathrm{Na}_{2} \mathrm{HPO}_{4}, 2.1 ; \mathrm{NaH}_{2} \mathrm{PO}_{4} \cdot \mathrm{H}_{2} \mathrm{O}, 11.76$; in distilled water. (0.1 M, $\mathrm{pH}$ 6.0), was added to each tube and gently mixed by hand. An $\mathrm{HCl}:$ pepsin solution (5 ml), composition ( $\mathrm{g} / \mathrm{L})$ : pepsin, 1 ; $(\mathrm{ml} / \mathrm{L}) \mathrm{HCl}$; 15 ; in distilled water, was then added to each tube and gently mixed by hand (combined ph, 2.0). To

prevent bacterial growth, especially during the second stage, $0.25 \mathrm{ml}$ chloramphenicol solution, composition ( $\mathrm{g} / \mathrm{L})$ : chloramphenicol, 5 ; in $95 \%$ ethanol, was added to each tube and gently mixed by hand (Boisen and Fernandez, 1991). Each tube was sealed with a \#5 one-hole rubber stopper fitted with a one- 
way gas release valve (Bel-Art Products, Pequannock, NJ). The tubes were incubated at $39^{\circ} \mathrm{C}$ in a reciprocating water bath set at 70 RMP (2876, Thermo/Precision Scientific, Asheville, NC) for 6 hours and mixed hourly by hand.

\section{Stage 2}

Sodium hydroxide $(2.9 \mathrm{ml} 0.5 \mathrm{M})$, was added to each tube to reach a $\mathrm{pH}$ of 6.8. 5 $\mathrm{ml}$ of a pancreatin phosphate buffer, composition (g/L): $\mathrm{Na}_{2} \mathrm{HPO}_{4}$, 16.5; $\mathrm{NaH}_{2} \mathrm{PO}_{4} \cdot \mathrm{H}_{2} \mathrm{O}, 11.56$; porcine pancreatin, 5; in distilled water $(\mathrm{pH} 6.8)$, was added to each tube and gently mixed by hand to suspend the sample in solution. Tubes were sealed with the same rubber stopper and gas release valve as in stage 1 and incubated at $39^{\circ} \mathrm{C}$ in a reciprocating water bath, set at $70 \mathrm{RMP}$, for 18 hours.

\section{Centrifuging}

Three sets of 8 tubes were centrifuged for $15 \mathrm{~min}$ at room temperature at $6,750 \mathrm{x}$ g after removing the rubber stopper (Centrifuge: 5804 R Eppendorf, Hauppauge, NY; Rotor: F-34-6-38, Eppendorf, Hauppauge, NY). After centrifuging the supernate was removed from the tube and discarded. Rubber stoppers were replaced on the same tube and tubes were frozen at $-20^{\circ} \mathrm{C}$ (Frigidaire Commerical, Martinez, GA) until needed for stage 3. 


\section{Stage 3}

Stage 3 was conducted three separate times, once for each set of 8 tubes. Media was prepared according to composition (Table 13 and Appendix S). One set of 8 tubes was removed from the freezer and allowed to defrost at room temperature. $26 \mathrm{ml}$ of media was added to each tube after flushing the media with copper dried $\mathrm{CO}_{2}$ for $30 \mathrm{~min}$ and flushing the individual tube for $1 \mathrm{~min}$. Rubber stoppers were replaced on the same tube. Tubes were stored at $4^{\circ} \mathrm{C}$ in a refrigerator for 15 hours. After 15 hours tubes were warmed to $39^{\circ} \mathrm{C}$ in a reciprocating water bath. 
Table 13. Composition of anaerobic media used in stage 3.

\begin{tabular}{|c|c|}
\hline Component & Concentration \\
\hline & $\mathrm{mL} / \mathrm{L}$ \\
\hline Mineral solution $A^{a}$ & 330 \\
\hline Mineral solution $\mathrm{B}^{\mathrm{b}}$ & 330 \\
\hline Distilled water & 296 \\
\hline Water soluble vitamin solution ${ }^{c}$ & 20 \\
\hline Trace mineral solution ${ }^{d}$ & 10 \\
\hline Folate:biotin solution ${ }^{\mathrm{e}}$ & 5 \\
\hline Riboflavin solution ${ }^{f}$ & 5 \\
\hline Hemin solution ${ }^{g}$ & 5 \\
\hline Resazurin solution ${ }^{\mathrm{h}}$ & 1 \\
\hline \multirow[t]{2}{*}{ Short-chain fatty acid mix } & 0.4 \\
\hline & $\mathrm{g} / \mathrm{L}$ \\
\hline Sodium carbonate & 4 \\
\hline Yeast extract & 0.5 \\
\hline Trypticase & 0.5 \\
\hline Cysteine $\mathrm{HCl}$ monohydrate & 0.5 \\
\hline
\end{tabular}

${ }^{a}$ Composition (g/L): $\mathrm{NaCl}, 5.4 ; \mathrm{KH}_{2} \mathrm{PO}_{4}, 2.7 ; \mathrm{CaCl}_{2} \cdot 2 \mathrm{H}_{2} \mathrm{O}, 0.18 ; \mathrm{MgCl}_{2} \cdot 6 \mathrm{H}_{2} \mathrm{O}$, $0.12 ; \mathrm{MnCl}_{2} \cdot 4 \mathrm{H}_{2} \mathrm{O}, 0.06 ; \mathrm{CoCl}_{2} \cdot 6 \mathrm{H}_{2} \mathrm{O}, 0.06 ;\left(\mathrm{NH}_{4}\right)_{2} \mathrm{SO}_{4}, 5.4$; in distilled water. ${ }^{b}$ Composition $(\mathrm{g} / \mathrm{L}): \mathrm{K}_{2} \mathrm{HPO}_{4}$, 2.7; in distilled water.

'Composition (mg/L): EDTA (disodium salt), 500; $\mathrm{FeSO}_{4} \cdot 7 \mathrm{H}_{2} \mathrm{O}, 200$; $\mathrm{ZnSO}_{4} \cdot 7 \mathrm{H}_{2} \mathrm{O}, 10 ; \mathrm{MnCl}_{2} \cdot 4 \mathrm{H}_{2} \mathrm{O}, 3 ; \mathrm{H}_{3} \mathrm{PO}_{4}, 30 ; \mathrm{CoCl}_{2} \cdot 6 \mathrm{H}_{2} \mathrm{O}, 20 ; \mathrm{CuCl}_{2} \cdot 2 \mathrm{H}_{2} \mathrm{O}, 1$; $\mathrm{NiCl}_{2} \cdot 6 \mathrm{H}_{2} \mathrm{O}, 2 ; \mathrm{Na}_{2} \mathrm{MoO}_{4} \cdot 2 \mathrm{H}_{2} \mathrm{O}, 3$; in distilled water.

${ }^{d}$ Composition (mg/L): thiamin. $\mathrm{HCl}, 100$; pantothenic acid, 10; niacin, 100; pyridoxine, 100; $p$-aminobenzoic acid, 5; vitamin $\mathrm{B}_{12}, 0.25$; in distilled water. ${ }^{e}$ Composition (mg/L): folic acid, 10; biotin, 2; $\left(\mathrm{NH}_{4}\right)_{2} \mathrm{CO}_{3}, 100$; in distilled water. ${ }^{f}$ Composition (mg/L): riboflavin, 10; in 5 mM HEPES.

${ }^{9}$ Composition (mg/L): hemin, 500; in $10 \mathrm{mM} \mathrm{NaOH}$.

${ }^{\mathrm{h}}$ Composition $(\mu \mathrm{l} / \mathrm{ml})$ : $n$-valerate, 250 ; isovalerate, 250 , isobutyrate, 250 , and $\mathrm{DL}$ a-methylbutyrate, 250.

'Composition (g/L): resazurin, 1 ; in distilled water.

\section{Incolumn Preparation}

Feces were collected from three horses being fed exclusively Bermuda grass hay with access to pasture. Feces were collected by rectal palpation, and stored in plastic bags at $30-40^{\circ} \mathrm{C}$ by placing hot water in bottles in a Styrofoam cooler. 
Fecal inoculum was prepared by diluting feces $1: 10$ in prewarmed $\left(39{ }^{\circ} \mathrm{C}\right)$ anaerobic diluting solution (composition Table 14 and Appendix W ) and blending for 15 seconds in a waring blender (Waring Products, Torrington, CT) fitted with a sterile Eberbach semi-micro container (8580, Eberbach corporation, Ann Arbor, MI). Blended diluted feces were strained through 4 layers of cheesecloth and transferred to a sterile $100 \mathrm{ml}$ serum bottle after flushing with $\mathrm{CO}_{2}$. The serum bottle was fitted with a rubber serum bottle seal with aluminum cap and sealed. Inoculumn (4 ml) was injected into each tube through the rubber stopper using a $5 \mathrm{ml}$ syringe fitted with an 18 ga needle. Tubes were mixed gently and placed in the reciprocating water bath for 24 hours. Tubes were mixed using a vortexer (945404, Fisher Scientific, Pittsburgh, PA) every hour for the first 9 hours then every three hours overnight.

Table 14. Composition of anaerobic diluting solution used to dilute feces in stage 3.

\begin{tabular}{|c|c|}
\hline Component & Concentration \\
\hline $\begin{array}{l}\text { Distilled water } \\
\mathrm{NaHCO}_{3} \text { solution } \\
{\text { Mineral solution } 1^{\mathrm{b}}}^{\mathrm{b}} \\
\text { Mineral solution } 2^{\mathrm{C}} \\
\text { Resazurin solution }\end{array}$ & $\begin{array}{l}\mathrm{ml} / \mathrm{L} \\
854 \\
70 \\
37.5 \\
37.5 \\
1\end{array}$ \\
\hline Cysteine $\mathrm{HCl}$ monohydrate & $\frac{\mathrm{g} / \mathrm{L}}{0.5}$ \\
\hline
\end{tabular}
${ }^{a}$ Composition (g/L); $\mathrm{NaHCO}_{3}, 91$; in distilled water. (1.0832 M).

${ }^{b}$ Composition $(\mathrm{g} / \mathrm{L}) ; \mathrm{K}_{2} \mathrm{HPO}_{4}, 6$; $\mathrm{HOC}(\mathrm{COONa})\left(\mathrm{CH}_{2} \mathrm{COONa}\right)_{2} \cdot 2 \mathrm{H}_{2} \mathrm{O}$, 2; in distilled water.

'Composition (g/L); NaCl, $12 ;\left(\mathrm{NH}_{4}\right)_{2} \mathrm{SO}_{4}, 12 ; \mathrm{KH}_{2} \mathrm{PO}_{4}, 6 ; \mathrm{CaCl}_{2} \cdot 2 \mathrm{H}_{2} \mathrm{O}$, 1.2; $\mathrm{MgSO}_{4} \cdot 7 \mathrm{H}_{2} \mathrm{O}, 2.46 ; \mathrm{HOC}(\mathrm{COONa})\left(\mathrm{CH}_{2} \mathrm{COONa}\right)_{2} \cdot 2 \mathrm{H}_{2} \mathrm{O}, 20$; in distilled water. ${ }^{\mathrm{d} C}$ Composition ( $\left.\mathrm{g} / \mathrm{L}\right)$ : resazurin, 1 ; in distilled water. 


\section{Precipitation}

Incubation of one set of 8 tubes were stopped by precipitation after stage 2 as a quality control checkpoint. Tube contents were transferred to $400 \mathrm{ml}$ Berzelius beakers with four volumes of $95 \%$ ethanol (CAS 64-17-5) and allowed one hour to precipitate the soluble carbohydrate fractions (Sunvold et al., 1995).

\section{Filtering}

Whatman 541 filter papers, $15 \mathrm{~cm}$ diameter, were labeled in pencil, placed on a wire screen and transferred to a forced air oven (Blue M Electric Company, Blue Island, IL) and dried at $105^{\circ} \mathrm{C}$ for 18 hours. Filter papers were removed from the oven, placed in a dessicator for 15 minutes and weighed to the nearest $0.0001 \mathrm{~g}$ using a digital scale (XS205, Mettler Toledo, Columbus, OH) fitted with a small ErgoClip basket (Mettler Toledo, Columbus, $\mathrm{OH}$ ).

The supernate from the above precipitation was decanted into the filter papers fitted inside a glass funnel (long stem 58, Kimax) affixed to a vaccum manifold (DS0345, Nalgene Labware, Rochester, NY) with a \#8 one hole rubber stopper (Fisherbrand, Pittsburgh, PA). The solid precipitate was washed with $78 \%$ ethanol to rinse out remaining soluble components (Sunvold et al., 1995), using two separate $10 \mathrm{ml}$ washes and then the precipitate was transferred to the filter paper with additional $78 \%$ ethanol according to the procedures described by Shugar and Ballinger (1996). The filter paper was then rinsed with 95\% ethanol in two separate $10 \mathrm{ml}$ rinses to dilute water remaining in the residue (Sunvold et 
al., 1995). Using two separate $10 \mathrm{ml}$ portions, filter paper was given a final acetone rinse to remove residual pigments and dry the residue (Sunvold et al., 1995). Precipitation and filtering methods were the same at the end of stage 2 and 3.

\section{Dry Matter Loss (DML)}

Filter paper containing sample residue were placed on a wire screen and transferred to a forced air oven (Blue M Electric Company, Blue Island, IL) and dried at $105^{\circ} \mathrm{C}$ for 24 hours. Filter papers were removed from the oven, placed in a dessicator for 15 minutes, and then weighed to the nearest $0.0001 \mathrm{~g}$ using a digital scale (XS205, Mettler Toledo, Columbus, OH) to determine DML. The following equation was used to calculate \% DML (residue weights are filter paper containing residue):

$$
\% D M L=1-\frac{\text { residue weight }- \text { blank residue weight }}{\text { sample weight }(\text { DM Basis })} \times 100
$$

\section{Organic Matter Loss (OML)}

Filter papers containing residue were ashed in a muffle furnace (M-525 Series II, DENTSPLY Neytech ${ }^{\text {TM }}$ Equipment, York, PA) to determine OML (NFTA, 1993). The following equation was used to calculate $\% \mathrm{OML}$ (residue weights are filter paper containing residue):

$\% O M L=1-\frac{(\text { residue weight }- \text { residue ash weight })-(\text { blank residue weight }- \text { blank ash weight })}{\text { sample weight }(\text { OM Basis })} \times 100$ 


\section{Results}

Table 15. Average \% DML ( \pm SD) and average \% OML ( \pm SD), with corresponding $\% \mathrm{CV}, \mathrm{n}=5$ for each set. ${ }^{1}$

\begin{tabular}{lllll}
\hline & $\%$ DML & \% CV & $\%$ OML & $\%$ CV \\
\hline Stage 1/2 & $15.84 \pm 2.06$ & 13.01 & NA & NA \\
Stage 3, Set 1 & $48.33 \pm 3.17$ & 6.56 & $53.81 \pm 4.39$ & 8.16 \\
Stage 3, Set 2 & $41.01 \pm 5.22$ & 12.73 & $53.09 \pm 1.56$ & 2.94 \\
Stage 3, Set 3 & $46.05 \pm 1.50$ & 3.26 & $57.56 \pm 0.88$ & 1.52 \\
\hline
\end{tabular}

${ }^{1}$ Abbreviations: $\mathrm{DML}=$ dry matter loss, $\mathrm{OML}=$ organic matter loss, $\mathrm{CV}=$ coefficient of variation.

Results related to method development are detailed in Appendix (A). 


\section{Discussion}

In this study, in vitro results for DML and OML were numerically lower than those observed in vivo. As method development progressed and techniques were improved these differences were reduced. DML after stage 3 was similar between the three final attempts (Figure 2). This is attributed to the effort to keep techniques and conditions between final attempts the same. Similar results indicate reliable methodology and good technique.

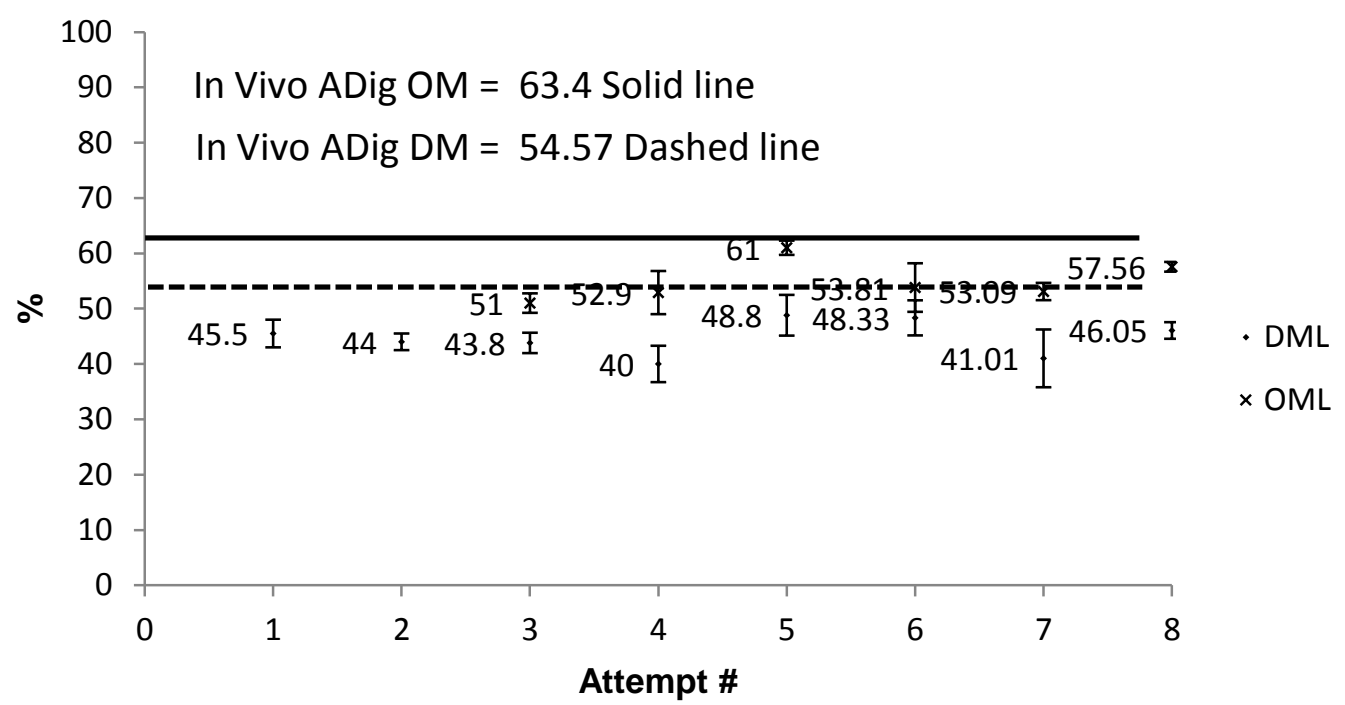

Figure 2. Average \% DML ( \pm SD) and average \% OML ( \pm SD) after stage 3 using


correspond to sets 1-3 of final reported results for stage 3 .

${ }^{1}$ Abbreviations: $\mathrm{DML}=$ dry matter loss, $\mathrm{OML}=$ organic matter loss . 


\section{Method Reliability/Coefficient of Variation}

As stated earlier, a reliable in vitro digestibility method would provide timely and cost-efficient evaluation of nutrient utilization and also allow for quality control of processed feeds. However, the value of an in vitro method is measured by how accurately it represents processes in vivo (Tamminga and Williams, 1998). Differences between observed values of DML in vivo and in vitro within this study can be expected as the focus of this study was on in vitro method and technique development. The method as currently reported could be further improved for equines by adapting incubation duration, $\mathrm{pH}$, and temperature to more closely match what is observed in vivo. Overall the method as reported shows promising trends towards reliability and consistency within and between trials.

The coefficient of variation (CV) was used to measure variation within each trial and allow comparison between trials as method development progressed. Although there are no published acceptable CV levels for in vitro digestibility methods, a CV of $5 \%$ or lower is generally considered excellent and $10 \%$ or lower acceptable for related and similar laboratory procedures (Layton, 2010; Zady, 1999; Damiran et al., 2008). CV's for DML decreased dramatically as the methods improved from the initial attempt at $36.4 \%$ after stage 2 (Appendix A) to $13.01 \%$ in the final attempt. Because stopping tubes after stage 2 is a quality control measure, a low $\mathrm{CV}$ at this point indicates excellent technique throughout stages 1 and 2. CV's for DML after stage 3 were generally low throughout method development and the only occurrence over $10 \%$ was set 2 of the final 
attempt (Figure 2). CV's for OML after stage 3 stayed below $5 \%$ throughout method development except for one occasion at $8.16 \%$ that occurred after set 1 of the final method.

\section{DML}

Lowman et al. (1999) observed DML alone was a poor predictor of in vivo digestibility values although when used in conjunction with cumulative gas production values estimation was improved. Ideally in vitro studies should measure multiple parameters to best correlate in vivo and in vitro digestibility.

\section{Batch System}

Differences between in vivo processes and in vitro laboratory procedures are numerous. While more work can be done to perfect in vitro digestibility methods, inherent flaws may exist within batch systems. Differences may be caused by the less complex microbial environment that exists within test tubes than within the digestive tract (Tamminga and Williams, 1998).

Although in vivo events and conditions may provide a starting place for method development, the nature of in vitro processes does not require exact replication and differences are required to obtain accurate results. Tamminga and Williams (1998) suggest end product recycling within batch systems can cause deviations from results observed in vivo and substrate to buffer ratios (substrate concentration) should be lower than that found in vivo. Additionally pancreatin 
may contain different relative amounts of digestive enzymes than those measured in equines in vivo (Lorenzo-Figueras et al. 2007).

\section{Filtering Methods}

The highest DML observed after stage 1/2 occurred during method development when medium porosity gooch crucibles were used for filtering. Crucibles were desired for filtering over paper as filtering was generally quicker, and results were less variable. This may be because crucibles are more accurately weighed than paper. The medium porosity crucibles retain particles larger than 10 to $15 \mu \mathrm{m}$. Whatman 541 filter paper retains particles larger than $22 \mu \mathrm{m}$. As the filter paper has a larger pore size, one would expect a higher estimate of DML when using this method, however the reverse was observed. Possible explanations include longer filtering times may lead to agglutination of substances (Lowman, 1999), and reduced surface area at the point of filtration (when filter papers are folded to fit inside a funnel), both possibly causing filter pores to clog. Initial attempts at crucible use for filtering were highly successful when considering both results and ease of use.

Because filtering methods using medium gooch crucibles resulted in estimations of DML closer to in vivo values after stage 2 than those estimations obtained using filter paper, and results had low variability, crucibles were the method of choice. Problems occurred when crucibles were used for the second time, leading to filter failure and total loss of samples. Problems with crucibles clogging 
after the first use were never able to be mediated despite attempts at proper use, washing, drying, ashing, and communication with the manufacturer. After no suitable solution could be reached, the decision was made to use Whatman 541 filter paper for all subsequent in vitro attempts.

The method used to weigh filter paper was changed to help reduce variability. Had crucibles been successfully re-used estimations of DML after stage 3 may have been higher and closer to those values observed in vivo. Switching back to filter paper after multiple attempts with new crucibles explains the lower DML observed in final reported data for stage 2 (Figure 3).

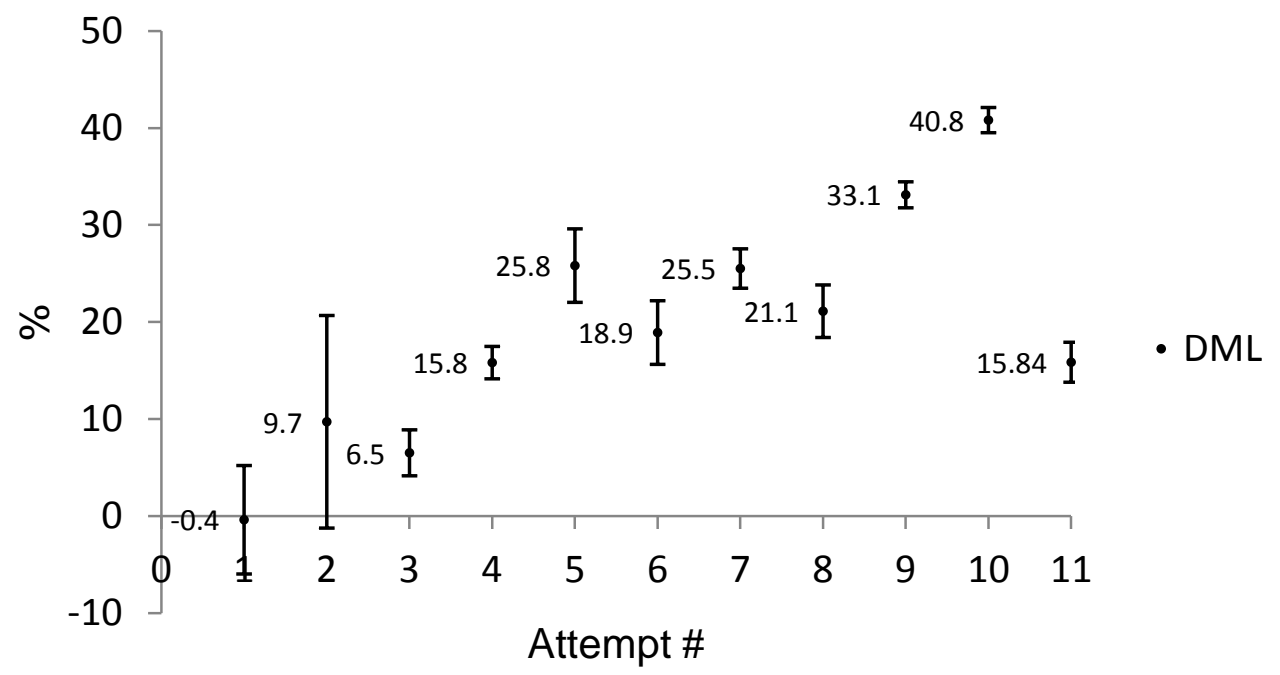

Figure 3. Average \% DML ( \pm SD) after stage 2 using the control feed ${ }^{1}$. Attempts 1-10 correspond to method development, attempt 11 corresponds to final reported results for stage 2 .

${ }^{1}$ Abbreviations: $\mathrm{DML}=$ dry matter loss. 


\section{Fecal Inoculumn Preparation}

Lowgren et al. (1988) obtained increased DML and less variable results when microbial inoculumn was centrifuged prior to use by removing large particles and mucus that could clog filters or add unnecessary weight. Lowgren et al. (1988) suggests centrifuging microbial inoculumn between $60-90 \mathrm{~g}$ for 5 minutes prior to use and cautions against higher speeds that may remove certain microbial fractions. Fecal inoculumn was filtered through 4 layers of cheesecloth before use as outlined in the protocol although this did not remove all small to medium particles.

Vince et al. (1976) observed viable microorganism counts remained unaltered over $48 \mathrm{~h}$ when feces were diluted to $25 \%$ in saline and incubated at $37^{\circ} \mathrm{C}$. When feces were diluted to $33 \%$ significant changes occurred after 24 h (Vince et al., (1976). Methods described in this paper dilute feces to $10 \%$ and incubate at $39^{\circ} \mathrm{C}$, therefore microbial populations were expected to remain viable during the first $24 \mathrm{~h}$.

\section{Fecal Inoculumn Source}

Lattimer et al. (2007) observed good correlation between in vitro and in vivo values when equine inoculumn donors were adapted to the diet being studied in vitro. Due to the very low sample size of this study $(n=2)$ and other reports concluding adapting inoculumn donors had no effect (Barry et al., 1995; Daniel et 
al.,1997), more research is required in this area. In the current study, inoculumn donors were not adapted to the experimental diets due to low diet availability.

Every attempt was made to keep methods exactly the same between sets for stage 3 , however due to scheduling issues or miscommunication, 1-2 donor equines may have varied and access to pasture may have varied prior to inoculumn collection. The effects of the possible variation cannot be known and ideally future in vitro studies will keep donor equines consistent and on the same diet between sample sets. Future studies should also attempt to determine the effects of adapting inoculumn donors to the test diet.

\section{Additional Method Development}

Additional method development may be required to further reduce variation in final in vitro results. The current methods detailed in this paper describe decanting the supernate from tubes centrifuged after the end of stage 2. Tubes are then frozen with remaining fluid and solids. After further research into the methods and communication with other laboratories, freeze drying seems the most appropriate action to take after centrifuging and decanting (Bauer, 2010). Because amounts of liquid remaining in each tube after decanting is not consistent, freeze drying would allow a more consistent starting point for stage 3 . A freeze-dryer was not available upon completion of this project. 
Extreme care must be taken when decanting supernate from centrifuged tubes, as particle loss can easily occur. Also tubes may need multiple attempts at centrifuging and decanting. Because the methods involve numerous steps requiring accuracy and precision, human error may be the largest source of variability between and within runs. The results reported here included instances of personnel training during final attempts and constant personnel turn-over. Proper training should occur prior to starting a study and personal should be kept consistent throughout.

In a human study, Daniel et al., (1997) bubbled flasks constantly with $\mathrm{CO}_{2}$ during incubation and observed good correlation between in vivo and in vitro values. In the current methods, tube contents are assumed to be anaerobic initially, however continuous flushing may be required. 


\section{CONCLUSIONS}

\section{$\underline{\text { In Vivo }}$}

When harness success values of "Off" were included in statistical analysis, there was a trend for $\mathrm{aDig}_{\mathrm{DM}}$ to differ between the two experimental diets. Apparent digestibility (DM) was significantly different between harness success values of "Off" and "On" with aDig values were removed and data were reanalyzed the observed differences in aDig ${ }_{D M}$ between the two experimental diets were not detected.

Hygiene harness must be emptied at least three times daily to accurately collect all feces and prevent loss. Hygiene harness problems can also be prevented by monitored horses $24 \mathrm{~h}$ per day and keeping them from being able to physically reach each other. No differences were seen in aDig of NDF, ADF, ADLOM or OM between the two experimental diets.

No significant difference in DMI or DME was observed between the two experimental diets. Body weight did not differ significantly between diets however there was an increase in BW during phase 2 of in vivo trials.

The effect of phase was not significant for all tests run on aDig, DMI, and DME. 


\section{In Vitro}

In vitro digestibility assay development preceded the in vivo evaluation. A threestage batch system as described by Boisen and Fernandez (1997) was utilized. This method was not thoroughly described anywhere in the literature. Through literature review, trial and error, and personal communication with other labs and product and chemical manufactures, careful documentation of the methods were detailed in over 34 pages of standard operating procedures (Appendix B-X).

Differences between observed values of DML in vivo and in vitro within this study can be expected as the focus of this study was on in vitro method and technique development. The method as currently reported could be further improved for equines by adapting incubation duration, $\mathrm{pH}$, and temperature to more closely match what is observed in vivo.

Freeze-drying sample tubes after stage 2 is the logical next step in method development to further reduce variation within in vitro digestibility trials.

The adaptation of inoculumn donors to the diet being studied in vitro should be the next step toward matching in vivo and in vitro digestibility trial results.

Overall the method as reported shows promising trends towards reliability and consistency within and between trials. 
Both the in vivo and in vitro methods described here can provide the foundation for future digestibility research at Cal Poly and beyond. 


\section{Literature Cited}

Alexander, F. 1966. A study of parotid salivation in the horse. J. Physiol. 184: 646-656.

Alexander, F. and J. C. D. Hickson. 1969. The salivary and pancreatic secretions of the horse. In Physiology of Digestion and Metabolism in the Ruminant, Proceedings of the Third International Symosium. Oriel Press, Cambridge, England.

American Horse Council Foundation, Deloitte Counsulting LLP. 2005. Economic impact of the horse industry on the United States. Washington, DC.

American Horse Publications. 2010. 2009-2010 AHP Equine Industry Survey. South Daytona, FL.

Ankom Technology. 2005. Method for determining acid detergent lignin in beakers. Macedon, NY.

Ankom Technology 2006. Method 5: Acid detergent fiber in feeds, filter bag technique. Macedon, NY.

Ankom Technology. 2006. Method 6: Neutral detergent fiber in feeds, filter bag technique. Macedon, N.Y.

Argenzio, R. A. 1990. Physiology of Digestive, Secretory, and Absorptive Processes. Page 434 In The Equine acute abdomen. N. A. White, ed. Lea \& Febiger, Malvern, PA. 
Argenzio, R. A., J. E. Lowe, D. W. Pickard, and C.E. Stevens. 1974. Digesta passage and water exchange in the equine large intestine. Am. J. Physiol. 226(5): 1035-1042.

Argenzio, R. A., M. Southworth, and C. E. Stevens. 1974. Sites of organic acid production and absorption in the equine gastrointestinal tract. Am. J. Physiol. 226(5): 1043-1050.

Barry, J.-L., C. Hoebler, G.T. MacFarlane, S. MacFarlane, J.C. Mathers, K.A. Reed, P.B. Mortensen, I. Nordgaard, I.R. Rowland, and C.J. Rumney. 1995. Estimation of the fermentability of dietary fiber in vitro: a European interlaboratory study. Br. J. Nutr. 74: 303-322.

Bauer, L. 2010. Personal Communication.

Boisen, S. and B. O. Eggum. 1991. Critical Evaluation of in Vitro Methods for Estimating Digestibility in Simple-Stomached Animals. Nutr. Res. Rev. 4: 141-162.

Boisen, S. and J. A. Fernandez. 1991. In vitro digestibility of energy and amino acids in pig feeds. Page 231 In Digestive Physiology in Pigs. Proceedings of the Vth International Symposium on Digestive Physiology in Pigs. M. W. A. Verstegen, J. Huisman and L. A. Hartog, eds. European Federation of Animal Science, Wageningen, Netherlands.

Boisen, S. F. and J.A. Fernandez. 1997. Prediction of the total tract digestibility of energy in feedstuffs and pig diets by in vitro analyses. Anim. Feed Sci. Tech. 68: 227-286. 
Coles, L. T., P. J. Moughan, and A. J. Darragh. 2005. In vitro digestion and fermentation methods, including gas production techniques, as applied to nutritive evaluation of foods in the hindgut of humans and other simplestomached animals. Anim. Feed Sci. Tech. 123: 421-444.

Colville, T. and J. M. Bassert. 2002. Clinical Anatomy and Physiology for Veterinary Technicians. Mosby, St. Louis, Ml.

Damiran, D., T. DelCurto, D.W. Bohnert, and S.L. Findholt. 2008. Comparison of techniques and grinding size to estimate digestibility of forage based ruminant diets. Anim. Feed Sci. Technol. 141: 15-35.

Daniel, M. E. Wisker, G. Rave, W. Feldheim. 1997. Fermentation in human subjects of nonstarch polysaccharides in mixed diets, but not in a barley fiber concentrate, could be predicted by in vitro fermentation using human fecal inocula. J Nutr. 127(10): 1981-8.

de Fombelle, A., M. Varloud, A-G. Goachet, E. Jacotot, C. Philippeau, C.

Drogoul, and V. Julliand. 2003. Characterization of the microbial and biochemical profile of the different segments of the digestive tract in horses given two distinct diets. Anim. Sci. 77: 3625-3634.

Edwards, C. A., G. Gibson, M. Champ. B-B Jensen, J.C. Mathers, F. Nagengast, C. Rumey, and A. Quehl. 1996. In vitro method for quantification of the fermentation of starch by human faecal bacteria. J. Sci. Food Ayric. 79: 209-217. 
Edwards, M., L. Lawrence, and C. O'Connor-Robison. 2011. Techniques, equipment and considerations applied in equine digestibility experiments, J. Equine Vet. Sci. 31(5-6): 276.

Ellis, A. D. and J. Hill. 2005. Nutritional Physiology of the Horse. Nottingham University Press, Nottingham, UK.

Frape, D. 2004. Equine nutrition and Feeding. Blackwell Publishing Ltd., Oxford, UK.

Glinsky, M. J., R. M. Smith, H.R. Spires, and C.L. Davis. 1976. Measurement of volatile fatty acid production rates in the cecum of the pony. J. Anim. Sci. 42: 1465-1470.

Goering, H. K. and P. J. Van Soest. 1970. Forage fiber analysis (Apparatus, Reagents, Procedures, and Some Applications). Handbook No. 379. Agricultural Research Service, United States Department of Agriculture.

Green, A. R., R. S. Gates, and L. M. Lawrence. 2005. Measurement of horse core body temperature. J. Therm. Biol. 30: 370-377.

Hintz, H. F. 1990. Digestive Physiology. The Horse. W.H. Freeman and Company, NY.

Holter, P. 1991. Concentration of oxygen, carbon dioxide, and methane in the air within dung pats. Pedobiologia. 35: 381-386.

Hume, I. D. 1997. Fermentation in the hindgut of mammals. Page 84 In Gastrointestinal Microbiology, vol. 1. R. L. Mackie and B. A. White, eds. Chapman \& Hall, NY. 
Julliand, V., A. de Fombelle, C. Drogoul, and E. Jacotot. 2001. Feeding and microbial disorders in horses: Part 3 -Effects of three hay:grain ratios on microbial profile and activities. J. Equine Vet. Sci. 21: 543-546.

Kern, D. L., L. L. Slyter, J. M. Weaver, E.C. Leffel, and G. Samuelsons. 1973. Pony cecum vs. steer rumen: The effect of oats and hay on microbial ecosystems. J. Anim. Sci. 37: 463-469.

Layton, B. 2010. Personal Communication.

Lattimer, J. M., S. R. Cooper, D.W. Freeman, and D.L. Lalman. 2007. Effect of yeast culture on in vitro fermentation of a high-concentrate or high-fiber diet using equine fecal inoculum in a Daisy II incubator. J. Anim. Sci. 85: 2484-2491.

Lorenzo-Figueras, M., S. M. Morisset, J. Morisset, J. Laine, and A. M. Merritt. 2007. Digestive enzyme concentrations and activities in healthy pancreatic tissue of horses. A. J. Vet. Res. 68(10): 1070-1072.

Lowgren, W., H. Graham, and P. Aman. 1989. An in vitro method for studying digestion in the pig 1. Simulating digestion in the different compartments of the intestine. B. J. Nutr. 61: 673-687.

Lowman, R. S., M. K. Theodorou, J.J. Hyslop, M.S. Dhanoa, and D. Cuddeford. 1999. Evaluation of an in vitro batch culture technique for estimating the in vitro digestibility and digestible energy content of equine feeds using equine faeces as the source of microbial inoculum. Anim. Feed Sci. Tech. 80: 11-27. 
Macheboeuf, D., M. Jestin, and W. Martin-Rosset. 1998. Utilization of the gas test method and horse faeces as a source of inoculum. Page 187 In In Vitro Techniques for Measuring Nutrient Supply to Ruminants, Vol. 22. E. R. Deaville, E. Owen, A. T. Adesoganet, C. Tymer, J. A. Huntington, T L. J. Lawrence, H. Davies, C. Wolliams, eds. Occasional Publication of the British Society of Animal Science, Edinburgh, UK.

Murray, J. M. D., A. C. Longland, M.J.S. Moore-Colyer, and C. Dunnett. 2003.

The effect of diet and donor animal on the fermentative capacity of equine faecal inocula for use in in vitro digestibility determinations. Eighteenth Equine Nutrition and Physiology Symposium. Equine Nutrition and Physiology Society., Lansing, MI. 121-123.

Murray, M. J. and G. F. Schusser. 1993. Measurement of 24-h gastric pH using an indwelling $\mathrm{pH}$ electrode in horses unfed, fed and treated with ranitidine. Equine Vet. J. 25: 417-421.

National Forage Testing Association (NFTA). Accessed June 20, 2012. <http://www.foragetesting.org/index.php?page=lab_procedures > NRC. 2007. Nutrient Requirements of Horses. 6th rev. ed. Natl. Acad. Press, Washington, DC.

Pond, W. G., D. C. Church, K.R. Pond, and P.A. Schoknecht. 2005. Basic Animal Nutrition and Feeding. Wiley, Hoboken, NJ.

Ringler, J., B. Cassill, S. Hayes, and L. Lawrence. 2005. Comparison of in vitro digestibility estimates using the daisy II incubator to in vivo digestibility 
estimates. Nineteenth Equine Science Society Symposium. Equine Science Society, Tucson, AZ. 307-308.

Schneider, B. H. and W. P. Flatt. 1975. The Evaluation of Feeds through Digestibility Experiments. The University of Georgia Press, Athens, GA.

Shugar, G. J. and J. T. Ballinger. 1996. Chemical Technicians Ready Reference Handbook. McGraw-Hill, Inc., New York, NY.

Stevens, E. and I. Hume. 1995. Comparative Physiology of the Vertebrate Digestive System. 2nd ed. Cambridge University Press, New York, NY. Sunvold, G. D., H. S. Hussein, G. C. Fahey Jr., N. R. Merchen, and G. A. Reinhart. 1995. In vitro fermentation of cellulose, beet pulp, citrus pulp, and citrus pectin using fecal inoculum from cats, dogs, horses, humans, and pigs and ruminal fluid from cattle. J. Anim. Sci. 73: 3639-3648.

Tamminga, S. and B. A. Williams. 1998. In vitro techniques as tools to predict nutrient supply in ruminants. Page 348 In In Vitro Techniques for Measuring Nutrient Supply to Ruminants. Vol. 22. E. R. Deaville, E. Owen, A. T. Adesoganet, C. Rymer, J. A. Huntington, T. L. J. Lawrence, H. Davies, C. Woolliams, eds. Occasional Publication of the British Society of Animal Science, Edinburgh, UK.

The Merck Veterinary Manual. Accessed May 3, 2010. $<$ http://www.merckvetmanual.com/mvm/index.jsp> The United States Pharmacopeial Convention. 2007. The United States Pharmacopeia. Vol. 3. 30th rev. ed. Port City Press, Baltimore, MD. 
Tighe, M. M. and M. Brown. 2002. Mosby's Comprehensive Review for Veterinary Technicians. Mosby, St Louis, MO.

Tilley, J. M. A. and R. A. Terry. 1963. A two-stage technique for the in vitro digestion of forage crops. J. Br. Grassland Soc. 18: 104-111.

Vince, A., P. F. Down, J. Murison, F. J. Twigg, and O. M. Wrong. 1976. Generation of ammonia from non-urea sources in a faecal incubation system. Clin. Sci. Mol. Med. 51: 313-322.

Zady, M. F. 1999. Z-4: Mean, standard deviation, and coefficient of variation. Accessed May 9, 2012. <http://www.westgard.com/lesson34.htm.> 


\section{APPENDICES}

Appendix A. In Vitro Evaluation Method Development.

Stage 3-Attempt $5(11 / 3 / 10)$ Control Lot 209-1mm (Stage 1/2 done 7/14/10)

DML

\begin{tabular}{llll}
\hline Standard Deviation & Average \% DML & CV \% & $\mathrm{N}$ \\
\hline 3.7 & 48.8 & 7.5 & 3 blanks, 10 samples \\
\hline
\end{tabular}

OML

\begin{tabular}{llll}
\hline Standard Deviation & Average \% OML & CV \% & $\mathrm{N}$ \\
\hline 1.28 & 61.0 & 2.1 & 3 blanks, 10 samples \\
\hline
\end{tabular}

Factors affecting results:

Media was flushed with copper dried $\mathrm{CO}_{2}$ after adding final reagents until it was dark brown in color, then added to tubes also flushed with copper dried $\mathrm{CO}_{2}$. Tubes were incubated for 24 hours and mixed hourly from $8 \mathrm{am}-5 \mathrm{pm}$ then every 3 hours until 8am. Filter paper was used for filtering. An ErgoClip small basket was used to weigh filter paper after restarting the scale, no pans were used for drying. Filtration method was corrected after textbook verification (Shugar and Ballinger, 1996).

Stage 3- Attempt $4(10 / 27 / 10)$ Control Lot 209- $1 \mathrm{~mm}$ (Stage 1/2 done 7/14/10) DML

\begin{tabular}{llll}
\hline Standard Deviation & Average \% DML & CV \% & $\mathrm{N}$ \\
\hline 3.3 & 40.0 & 8.0 & 3 blanks, 9 samples \\
\hline
\end{tabular}


OML

\begin{tabular}{llll}
\hline Standard Deviation & Average \% OML & CV \% & $\mathrm{N}$ \\
\hline 0.91 & 52.3 & 1.75 & 3 blanks, 9 samples \\
\hline
\end{tabular}

Factors affecting results:

Media was added to tubes when it was still red in color, indicating an aerobic rather than anaerobic solution. Media was flushed with copper dried $\mathrm{CO}_{2}$ while adding to tubes. Media changed back to dark brown when adding to the last tubes, indicating an anaerobic solution. Tubes were incubated for 24 hours and mixed hourly from 8am-5pm then every 3 hours until 8am. Filter paper was used for filtering, no pans were used when drying. An ErgoClip small basket was used to weigh filter paper. Filtration method was possibly incorrect.

Stage 3-Attempt $3(10 / 13 / 10)$ Control Lot 209 - $1 \mathrm{~mm}$ (No Stage 1/2- only Stage

3)

DML

\begin{tabular}{llll}
\hline Standard Deviation & Average \% DML & CV \% & $\mathrm{N}$ \\
\hline 1.8 & 43.8 & 4.2 & 3 blanks, 8 samples \\
\hline
\end{tabular}

OML

\begin{tabular}{llll}
\hline Standard Deviation & Average \% OML & CV \% & $\mathrm{N}$ \\
\hline 1.8 & 51.0 & 3.5 & 3 blanks, 8 samples \\
\hline
\end{tabular}

Factors affecting results:

Stage 3 run on dry feed samples not previously run through Stage 1/2. This means there was no aerobic solution in tubes prior to adding media. Tubes were 
incubated for 24 hours, and mixed hourly from $8 \mathrm{am}-5 \mathrm{pm}$ then every 3 hours until 8am. Filter paper was used for filtering. No pans were used to keep individual filter papers in while drying, removing an additional variable from the equation. An ErgoClip small basket was used to weigh filter paper. Filtration method was possibly incorrect.

Stage 3-Attempt $2(8 / 18 / 10)$ Control Lot 209-1mm (Stage 1/2 done 5/13/10) DML

\begin{tabular}{llll}
\hline Standard Deviation & Average \% DML & CV \% & $\mathrm{N}$ \\
\hline 1.5 & 44.0 & 3.5 & 3 blanks, 9 samples \\
\hline
\end{tabular}

Factors affecting results:

Copper dried $\mathrm{CO}_{2}$ was not used. Tubes were incubated for 24 hours and mixed hourly for the first four hours then ever two hours. Medium gooch crucibles were used for filtering and all clogged significantly. Filtering Stage 1/2 tubes was a total loss, no tubes were able to be filtered completely, therefore the quality control check after stage 2 is missing. An ErgoClip small basket was used to weigh filter paper. Filtration method was possibly incorrect.

Stage 3-Attempt $1(5 / 11 / 10)$ Control Lot 209-1mm (Stage 1/2 done 4/21/10) DML

\begin{tabular}{llll}
\hline Standard Deviation & Average \% DML & CV \% & $\mathrm{N}$ \\
\hline 2.5 & 45.2 & 5.6 & 3 blanks, 4 samples \\
\hline
\end{tabular}

Factors affecting results: 
Copper dried $\mathrm{CO}_{2}$ was not used. Gasing of media was done over the liquid, not bubbling in it, resulting in an aerobic solution rather than an anaerobic one. Media was dark red when gasing and when adding to tubes, also indicating an aerobic solution. Tubes were incubated for 24 hours and mixed every two hours from 9am-5pm and not mixed overnight at all. Medium gooch crucibles were used for filtering. An ErgoClip basket was used to weigh filter paper. Filtration method was possibly incorrect.

Stage 1/2-Attempt $10(7 / 14 / 10)$ Control Lot $209-1 \mathrm{~mm}$ DML

\begin{tabular}{llll}
\hline Standard Deviation & Average \% DML & CV \% & $\mathrm{N}$ \\
\hline 1.3 & 40.8 & 3.2 & 2 blanks, 6 samples \\
\hline
\end{tabular}

Factors affecting results:

New medium gooch crucibles were used for filtering, there is no record of any problems with the crucibles clogging. Tubes were mixed hourly overnight.

Filtration method was possibly incorrect.

Stage 1/2-Attempt $9(4 / 21 / 10)$ Control Lot $209-1 \mathrm{~mm}$

DML- coarse and medium gooch crucibles

\begin{tabular}{llll}
\hline Standard Deviation & Average \% DML & CV \% & $\mathrm{N}$ \\
\hline 1.33 & 33.1 & 4.0 & 3 blanks, 8 samples \\
\hline
\end{tabular}


DML- medium crucibles only

\begin{tabular}{llll}
\hline Standard Deviation & Average \% DML & CV \% & $\mathrm{N}$ \\
\hline 1.3 & 32.7 & 3.9 & 3 blanks, 2 samples \\
\hline
\end{tabular}

Factors affecting results:

Medium and coarse gooch crucibles were used for filtering. \#5 rubber stoppers with no hole and no one-way valve were used with some gas build up in stage 2 .

Tubes were mixed every two hours from 9am-5pm, and not mixed overnight.

Filtration method was possibly incorrect.

Stage 1/2-Attempt 8 (12/8/09) Control Lot 209-1mm

DML

\begin{tabular}{llll}
\hline Standard Deviation & Average \% DML & CV \% & N \\
\hline 2.7 & 21.1 & 12.8 & 3 blanks, 9 samples \\
\hline
\end{tabular}

Factors affecting results:

Beads were used to aid mixing in the tubes and an average weight per bead was removed from the final equation. Tube start time was also staggered in groups but mixed evenly. Filtration method was possibly incorrect.

Stage 1/2-Attempt 7 (9/16/09) Control Lot 209-1mm

DML

\begin{tabular}{llll}
\hline Standard Deviation & Average \% DML & CV \% & $\mathrm{N}$ \\
\hline 2.0 & 25.5 & 8.0 & 3 blanks, 12 samples \\
\hline
\end{tabular}

Factors affecting results: 
Beads were used to aid mixing and an average weight per bead was removed from the final equation. Tube start time was also staggered in groups and possibly not mixed equally. Tubes were mixed every two hours from 9am-5pm, and not mixed overnight. Filter paper was used for filtering, the weight taken by folding on the scale. Filtration method was possibly incorrect.

Stage 1/2-Attempt 6 (8/26/09) Control Lot 209-1mm

DML

\begin{tabular}{llll}
\hline Standard Deviation & Average \% DML & CV \% & N \\
\hline 3.9 & 18.9 & 17.3 & 4 blanks, 20 samples \\
\hline
\end{tabular}

Factors affecting results:

No beads were used to aid mixing in the tubes. Tube start time was staggered in groups and may not have been mixed evenly. Tubes were mixed every two hours from $9 a \mathrm{~m}-5 \mathrm{pm}$, and not mixed overnight at all. Samples were ground to $1 \mathrm{~mm}$ for the first time. Filter paper was used for filtering, the weight taken by folding on the scale. Filtration method was possibly incorrect.

Stage $1 / 2$ - Attempt $5(8 / 11 / 09)$ Washout $2 \mathrm{~mm}$

DML

\begin{tabular}{llll}
\hline Standard Deviation & Average \% DML & CV \% & $\mathrm{N}$ \\
\hline 3.8 & 25.8 & 14.7 & 3 blanks, 27 samples \\
\hline
\end{tabular}

Factors affecting results: 
Pancreatin solution was centrifuged for the first time before use, removing large tissue particles and producing a more homogenous solution. Tubes were mixed about every two hours during stage 1 , tubes were mixed three times during stage

2 , and not mixed overnight at all. The particle size was too large, $2 \mathrm{~mm}$ vs $1 \mathrm{~mm}$.

Filtration method was possibly incorrect.

Stage 1/2-Attempt 4 (7/30/09) Washout 2mm

DML

\begin{tabular}{llll}
\hline Standard Deviation & Average \% DML & CV \% & $\mathrm{N}$ \\
\hline 1.7 & 15.8 & 10.6 & 3 blanks, 12 samples \\
\hline
\end{tabular}

Factors affecting results:

Particle size was still too large, $2 \mathrm{~mm}$ vs $1 \mathrm{~mm}$. Filter papers were weighed after a long time on the scale. The $\mathrm{pH}$ of solutions was corrected. Pancreatin solution was added to the buffer on the day of use, rather than the day before. Filtration method was possibly incorrect.

Stage 1/2- Attempt 3 (7/6/09) Washout 2mm

DML

\begin{tabular}{llll}
\hline Standard Deviation & Average \% DML & CV \% & $\mathrm{N}$ \\
\hline 2.4 & 6.5 & 36.4 & 3 blanks, 12 samples \\
\hline
\end{tabular}

Factors affecting results:

Samples were ground to $2 \mathrm{~mm}$, which is too large and not recommended.

Pancreatin solution was also not centrifuged before use which may be 
necessary. The $\mathrm{pH}$ of solutions was corrected. Filtration method was possibly incorrect.

Stage 1/2-Attempt 2 (6/23/09) Washout 2mm

DML

\begin{tabular}{llll}
\hline Standard Deviation & Average \% DML & CV \% & N \\
\hline 11.0 & 9.7 & - & 3 blanks, 6 samples \\
\hline
\end{tabular}

Factors affecting results:

The $\mathrm{pH}$ of solutions was not properly calibrated. The wrong particle size of $2 \mathrm{~mm}$ was used. Filter paper weight was taken after a long time on the scale. The pancreatin solution was not centrifuged or filtered in any way, leaving large tissue particles in solution. Beads were used to aid mixing but left in filter after filtration. An average of dry clean beads was removed from the final equation. The $\mathrm{pH}$ of tubes was taken during stage 1 with some sample loss observed on $\mathrm{pH}$ probe. The $\mathrm{pH}$ of stage 2 tubes was consistent. Filtration method possibly was incorrect.

\section{Stage 1/2-Attempt 1 (6/15/09) Washout 2mm}

DML

\begin{tabular}{llll}
\hline Standard Deviation & Average \% DML & CV \% & $\mathrm{N}$ \\
\hline 5.6 & -0.4 & - & 2 blanks, 7 samples \\
\hline
\end{tabular}

\section{Factors affecting results:}

The $\mathrm{pH}$ of solutions was not properly calibrated. The wrong particle size of $2 \mathrm{~mm}$ was used. Filter paper weight was taken after a long time on the scale. 
Pancreatin solution not centrifuged or filtered in any way, leaving large tissue particles in solution. Beads used to aid mixing were cleaned during filtering and weighed after, to be subtracted from the final equation and leading to some sample loss. Filtration method was incorrect. 
Appendix B. In Vitro Procedure.

\section{Animal Science Department}

Policies and Procedures

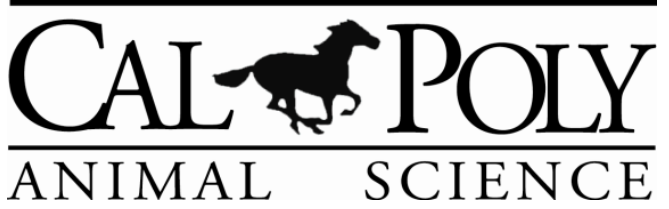

Title

Owner

Approval

Revision Level

Revision Date
In Vitro Digestion Assay - two/three stage for any monogastric Cassandra Sweeney

Mark S. Edwards, Ph.D., Associate Professor

7

29-March-2012

\begin{tabular}{|c|c|}
\hline \multirow[t]{2}{*}{ References: } & Bauer, L. Personal communication, 2008-9 \\
\hline & $\begin{array}{l}\text { Boisen, S., In Vitro Digestion for Pigs and Poultry, ed. M. F. Fuller, } \\
\text { 1991, 135-145 }\end{array}$ \\
\hline & Boisen and Eggum, Nutr. Res. Rev. 4:141-162 \\
\hline & Bourquin, Titgemeyer and Fahey, 1993, J. Nutr. 123(5):860-869 \\
\hline & $\begin{array}{l}\text { Shugar, Gershon J. and Ballinger, Jack T. The Chemical Technicians } \\
\text { Ready Reference Handbook. Fourth Edition. 1996. McGraw-Hill, Inc. }\end{array}$ \\
\hline Equipment: & TBD \\
\hline Reagents: & TBD \\
\hline Preparation: & Samples should be ground to $1 \mathrm{~mm}$ particle size \\
\hline & $\begin{array}{l}\text { 1. Mix } 12.5 \mathrm{ml} \text { phosphate buffer with } 5 \mathrm{ml} \mathrm{HCl} \text { : pepsin solution and } \\
\text { check pH (target } \mathrm{pH} \sim 2.0 \pm 0.1) \text {. }\end{array}$ \\
\hline & $\begin{array}{l}\text { 2. Add (4) } \mathrm{ml} \mathrm{NaOH} \text { solution to above mixture and check } \mathrm{pH} \text { (target } \\
\mathrm{pH} \sim 6.8-7.0 \text { ). Adjust } \mathrm{NaOH} \text { added to reach target } \mathrm{pH} \text { range. } \\
\text { Record the amount needed, this is the amount added at step } 15 .\end{array}$ \\
\hline & $\begin{array}{l}\text { 3. Place labeled Medium gooch crucibles or Whatman } 54115 \mathrm{~cm} \\
\text { filter paper in the oven and weigh the next day (crucible or filter } \\
\text { paper tare weight). }\end{array}$ \\
\hline & 4. Prepare one set of tubes to stop at end of stage 2 (after step 16). \\
\hline
\end{tabular}




\begin{tabular}{|c|c|}
\hline & 5. Prepare one set of tubes for each inoculum donor/stage 3 pull time. \\
\hline & 6. Weigh $0.5 \mathrm{~g}$ sample into each tube; record weight (sample weight). \\
\hline & $\begin{array}{l}\text { 7. Prepare one set of three blanks to stop at end of stage } 2 \text { (after step } \\
\text { 16). }\end{array}$ \\
\hline & $\begin{array}{l}\text { 8. Prepare one set of three blanks for each inoculum donor/stage } 3 \\
\text { pull time. }\end{array}$ \\
\hline Stage 1 & $\begin{array}{l}\text { 9. Add } 12.5 \mathrm{ml} \text { phosphate buffer to each tube; mix to suspend sample } \\
\text { in buffer. }\end{array}$ \\
\hline & 10. Add $5 \mathrm{ml} \mathrm{HCl}$ : pepsin solution to each tube. \\
\hline & 11. Add $0.25 \mathrm{ml}$ chloramphenicol solution to each tube. \\
\hline & 12. Stopper each tube and mix gently. \\
\hline & 13. Incubate at $39^{\circ} \mathrm{C}$ at $(70 \mathrm{RPM})$ for $6 \mathrm{~h}$. \\
\hline & 14. Mix hourly. \\
\hline Stage 2 & 15. Add (4) $\mathrm{ml} 0.5 \mathrm{~N} \mathrm{NaOH}$ solution to each tube. \\
\hline & $\begin{array}{l}\text { 16. Add } 5 \mathrm{ml} \text { pancreatin: phosphate buffer to each tube and mix } \\
\text { gently. }\end{array}$ \\
\hline & 17. Stopper each tube and mix gently. \\
\hline & 18. Incubate at $39^{\circ} \mathrm{C}$ at $70 \mathrm{RPM}$ for $18 \mathrm{hr}$ \\
\hline & 19. Mix hourly. \\
\hline Precipitation & 20. Transfer the contents of the tubes to $400 \mathrm{ml}$ Berzelius beakers. \\
\hline Stage 2 and 3 & $\begin{array}{l}\text { 21. Add } 107 \mathrm{ml} 95 \% \text { ethanol if ending stage } 2 \text { and } 120 \mathrm{ml} 95 \% \text { ethanol } \\
\text { ending stage } 3 \text {. Rinse } 50 \mathrm{ml} \text { tube and stopper when adding ethano }\end{array}$ \\
\hline & 22. Precipitate for $1 \mathrm{hr}$ by allowing to sit undisturbed. \\
\hline$\underline{\text { Centrifuging }}$ & $\begin{array}{l}\text { 23. Remove stoppers from remaining tubes removing any sample from } \\
\text { stopper and transferring it back into the tube. }\end{array}$ \\
\hline & 24. Centrifuge tubes at $6,750 \mathrm{RCF}$ for 15 minutes. \\
\hline & 25. Pipette off and discard supernate. \\
\hline
\end{tabular}




\begin{tabular}{|c|c|}
\hline & 26. Replace stopper and place tubes in freezer. \\
\hline Filtering & $\begin{array}{l}\text { 27. Filter precipitated sample through medium gooch crucibles or filter } \\
\text { paper (from step 1) using a vaccum filtering manifold. }\end{array}$ \\
\hline \multirow[t]{6}{*}{ Stage 2 and 3} & 28. Decant supernate slowly into the filter paper using a glass rod. \\
\hline & $\begin{array}{l}\text { 29. Wash with } 3,10 \mathrm{ml} \text { portions of } 78 \% \text { ethanol, as } 3 \text { separate washes } \\
\text { allowing precipitate to settle for } 1 \text { minute then decant supernate. }\end{array}$ \\
\hline & $\begin{array}{l}\text { 30. Transfer the residue into the filter paper using } 78 \% \text { ethanol, and a } \\
\text { rubber policeman, also rinsing any residue from the glass rod into } \\
\text { the filter. }\end{array}$ \\
\hline & $\begin{array}{l}\text { 31. Wash the beaker with } 2,10 \mathrm{ml} \text { portions of } 95 \% \text { ethanol, as } 2 \\
\text { separate washes, transferring the liquid into the filter paper after } \\
\text { all liquid from the previous wash has passed through the filter. }\end{array}$ \\
\hline & $\begin{array}{l}\text { 32. Wash the beaker with } 2,10 \mathrm{ml} \text { portions of acetone, as } 2 \text { separate } \\
\text { washes, transferring the liquid into the filter paper after all liquid } \\
\text { from the previous wash has passed through the filter. }\end{array}$ \\
\hline & $\begin{array}{l}\text { 33. Remove the crucible or filter paper from the manifold and place on } \\
\text { wire screen. }\end{array}$ \\
\hline Drying & $\begin{array}{l}\text { 34. Allow residue and crucible or filter paper to dry in the ventilated } \\
\text { hood overnight. }\end{array}$ \\
\hline \multirow[t]{3}{*}{ Stage 2 and 3} & $\begin{array}{l}\text { 35. Transfer residue and crucible or filter paper to oven and dry at } 105 \\
\text { overnight. }\end{array}$ \\
\hline & $\begin{array}{l}\text { 36. Transfer residue and crucible or filter paper into desiccator and } \\
\text { cool to room temperature. }\end{array}$ \\
\hline & $\begin{array}{l}\text { 37. Weigh residue and crucible or filter paper } \\
\text { (residue + crucible weight). }\end{array}$ \\
\hline$\underline{\text { Stage } 3}$ & $\begin{array}{l}\text { 38. Start media preparation the morning of the day before tubes are } \\
\text { to be inoculated. }\end{array}$ \\
\hline \multirow[t]{3}{*}{ Media } & 39. Defrost tubes a couple hours before adding media. \\
\hline & 40. Add media to tubes the evening before tubes are to be inoculated. \\
\hline & $\begin{array}{l}\text { 41. Add } 26 \mathrm{ml} \text { media to tubes while flushing tubes with copper dried } \\
\mathrm{CO}_{2} \text {, making sure media is dark brown in color at the time of use } \\
\text { by flushing with copper dried } \mathrm{CO}_{2} \text {. }\end{array}$ \\
\hline
\end{tabular}




\begin{tabular}{|c|c|}
\hline & 42. Stopper each tube. \\
\hline & $\begin{array}{l}\text { 43. Allow sample in tube to hydrate in media overnight in the } \\
\text { refrigerator. }\end{array}$ \\
\hline \multirow[t]{8}{*}{ Inoculation } & $\begin{array}{l}\text { 44. Start fecal inoculumn preparation } 1 \text { hour before the start of the } \\
\text { scheduled incubation time. }\end{array}$ \\
\hline & $\begin{array}{l}\text { 45. Inoculate tubes with } 4 \mathrm{ml} \text { fecal inoculumn injecting the inoculumn } \\
\text { through the rubber stopper from each tube using an } 18 \mathrm{ga} \text { needle } \\
\text { and } 5 \mathrm{ml} \text { syringe. }\end{array}$ \\
\hline & 46. Mix gently. \\
\hline & 47. Incubate at $39^{\circ} \mathrm{C}$ at $70 \mathrm{RPM}$ for the scheduled incubation time. \\
\hline & $\begin{array}{l}\text { 48. Mix tubes according to the chosen mixing schedule for the } \\
\text { scheduled incubation time. }\end{array}$ \\
\hline & 49. Precipitate and filter tube contents as described above. \\
\hline & $\begin{array}{l}\text { 50. Dry and weigh residue and crucible or filter paper as described } \\
\text { above. }\end{array}$ \\
\hline & 51. Residue and filter paper may be ashed to determine \% IVOMD. \\
\hline \multicolumn{2}{|l|}{ Calculations: } \\
\hline \multicolumn{2}{|c|}{ residue weight $=($ residue + filter weight $)-$ filter tare weight } \\
\hline \multicolumn{2}{|c|}{$\% D M L=1-\frac{\text { residue weight }- \text { blank residue weight }}{\text { sample weight }(\text { DM Basis })} \times 100$} \\
\hline$\% O M L=1-\underline{\text { rest }}$ & $\frac{\text { weight }- \text { residue ash weight })-(\text { blank residue weight }- \text { blank ash weight })}{\text { sample weight }(\text { OM Basis })} \times 100$ \\
\hline
\end{tabular}


Appendix C. 95\% and 78\% Ethanol.

Animal Science Department

Policies and Procedures



Title $\quad 95 \%$ and $78 \%$ Ethanol

Owner Cassandra Sweeney

Approval Mark S. Edwards, Ph.D., Associate Professor

Revision Level 1

Revision Date 09-Nov-09

References: Tighe, Monica M. and Brown, Marg. 2002. Mosby's Comprehensive Review for Veterinary Technicians. $2^{\text {nd }}$ edn. Mosby. St. Louis.

\begin{tabular}{|c|c|}
\hline Solution \#: & 0 \\
\hline Use: & $\begin{array}{l}\text { Precipitation and filter rinse after Stage } 2 \text { of in vitro fermentation } \\
\text { Chloramphenicol Solution }\end{array}$ \\
\hline Equipment: & Graduated cylinders \\
\hline Reagents & $\begin{array}{l}\text { 99.5\% Ethanol CAS 64-17-5 } \\
\text { Distilled water }\end{array}$ \\
\hline Procedure & $\begin{array}{l}\text { Concentration of desired solution } \times \text { Volume of desired solution }= \\
\text { Concentration of stock } x \text { Volume of stock } \\
\text { 1. Use the above equation to calculate the resulting volume of } \\
\text { the diluted solution. } \\
\text { Diluent = Volume of desired solution - volume of stock } \\
\text { 2. Use the above equation to calculate the amount of distilled } \\
\text { water to add to your chosen volume of } 99.5 \% \text { ethanol. } \\
\text { 3. Add the calculated amount of distilled water to } 99.5 \% \text { ethanol } \\
\text { using graduated cylinders, mix well. } \\
\text { 4. Transfer to an air tight glass container. }\end{array}$ \\
\hline Storage & $\begin{array}{l}\text { Label the container with the solution name, concentration, date, } \\
\text { preparer's initials. Seal and store in the flammable cabinet. }\end{array}$ \\
\hline Expiration & Unknown \\
\hline
\end{tabular}

95\%: $189.5 \mathrm{ml}$ distilled water to $4 \mathrm{~L} 99.5 \%$ ethanol

78\%: $275.6 \mathrm{ml}$ distilled water to $1 \mathrm{~L} 99.5 \%$ ethanol

$826.9 \mathrm{ml}$ distilled water to $3 \mathrm{~L} 99.5 \%$ ethanol 
Appendix D. Phosphate Buffer.

Animal Science Department

Policies and Procedures

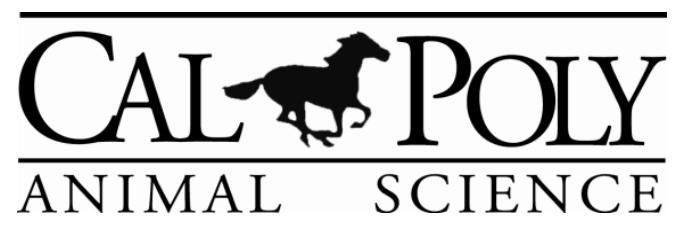

Title Phosphate Buffer, 0.1M, pH 6.0

Owner Cassandra Sweeney

Approval Mark S. Edwards, Ph.D., Associate Professor

Revision Level 6

Revision Date 29-March-2012

References: Bauer, L. Personal communication, 2008-9

\begin{tabular}{|c|c|}
\hline Solution \#: & 1 \\
\hline Use: & $12.5 \mathrm{ml}$ into each tube at stage 1 of in vitro fermentation. \\
\hline Equipment: & $\begin{array}{l}1 \text { liter volumetric flask } \\
1 \text { liter small mouth Pyrex jar with lid } \\
50 \text { ml beaker } \\
\text { Scale } \\
\text { Magnetic stir bar } \\
\text { Stir plate } \\
\text { pH Meter } \\
4 \times 4 \text { Weigh paper } \\
\text { Small metal scoop } \\
\text { Kimwipes }\end{array}$ \\
\hline Reagents: & $\begin{array}{l}2.1 \mathrm{~g} \text { Sodium Phosphate Dibasic, Anhydrous CAS 7558-79-4 } \\
11.76 \mathrm{~g} \text { Sodium Phosphate Monobasic, Monohydrate CAS 10049-21- } \\
5\end{array}$ \\
\hline Procedure: & $\begin{array}{l}\text { 1. Rinse the metal scoop with distilled water and dry with } \\
\text { Kimwipes before using on each reagent. } \\
\text { 2. Weigh each reagent onto the weigh paper and add to the } 1 \\
\text { liter flask successively. Some reagents may need to be } \\
\text { weighed in two portions. } \\
\text { 3. Add distilled water to the } 1 \text { liter flask until the volume reads } 1 \\
\text { liter. } \\
\text { 4. Add the stir bar to the } 1 \text { liter flask and place on the stir plate } \\
\text { and mix well. } \\
\text { 5. Add approximately } 20 \mathrm{ml} \text { phosphate buffer to the } 50 \mathrm{ml} \text { beaker } \\
\text { 6. Check the pH, target }(6.0 \pm 0.2) \text {. } \\
\text { 7. Transfer the solution to the Pyrex jar. }\end{array}$ \\
\hline
\end{tabular}




\begin{tabular}{|l|l|}
\hline Storage: & $\begin{array}{l}\text { Label the jar with the solution name, date, preparer's initials, and } \\
\text { time. } \\
\text { Seal the jar and store in the refrigerator. }\end{array}$ \\
\hline Expiration: & $48 \mathrm{hrs}$ after mixing \\
\hline
\end{tabular}


Appendix E. HCl Pepsin Solution.

Animal Science Department

Policies and Procedures

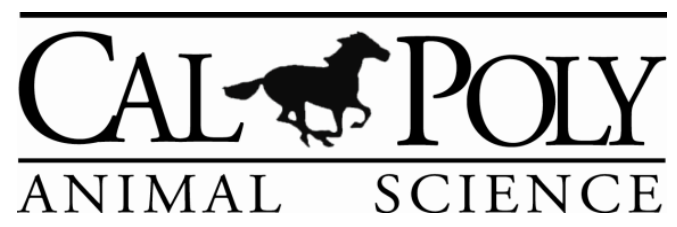

Title $\quad \mathrm{HCl}$ Pepsin Solution

Owner Cassandra Sweeney

Approval Mark S. Edwards, Ph.D., Associate Professor

Revision Level 2

Revision Date 18-Nov-2010

References: Bauer, L. Personal communication, 2008-9

\begin{tabular}{|c|c|}
\hline Solution \#: & 2 \\
\hline Use: & $5 \mathrm{ml}$ into each tube at stage 1 of in vitro fermentation. \\
\hline Equipment: & $\begin{array}{l}1 \text { liter volumetric flask } \\
10 \text { ml pipette } \\
\text { Scale } \\
3 \times 3 \text { Weigh paper } \\
\text { Small metal scoop } \\
\text { Acid gloves } \\
\text { Goggles } \\
\text { Silicone stopper to fit } 1 \text { liter volumetric flask }\end{array}$ \\
\hline Reagents: & $\begin{array}{l}1 \mathrm{~g} \text { Pepsin CAS 9001-75-6 } \\
15 \mathrm{ml} \mathrm{HCl} \text { CAS 7647-01-0 } \\
\text { Distilled Water }\end{array}$ \\
\hline Procedure: & $\begin{array}{l}\text { 1. Weigh the pepsin onto the weigh paper and add to the one } \\
\text { liter flask. } \\
\text { 2. Add approximately } 500 \mathrm{ml} \text { distilled water to the one liter flask } \\
\text { and mix until pepsin is completely dissolved. } \\
\text { 3. Wearing the gloves and goggles use the } 10 \mathrm{ml} \text { pipette to add } \\
15 \mathrm{ml} \mathrm{HCl} \text { to the one liter flask in two portions. } \\
\text { 4. Add distilled water to the } 1 \text { liter flask until the volume reads } 1 \\
\text { liter, mix well. }\end{array}$ \\
\hline Storage: & $\begin{array}{l}\text { Label the flask with the solution name, date, preparer's initials, and } \\
\text { time. } \\
\text { Seal the flask with the silicone stopper and store in the refrigerator. }\end{array}$ \\
\hline Expiration: & 60 days after mixing \\
\hline
\end{tabular}


Appendix F. Chloramphenicol Solution.

Animal Science Department

Policies and Procedures

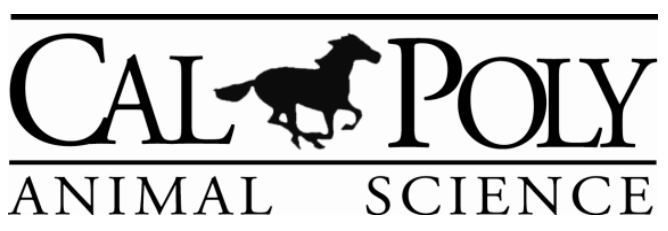

Title Chloramphenicol Solution

Owner Cassandra Sweeney

Approval Mark S. Edwards, Ph.D., Associate Professor

Revision Level 3

Revision Date 18-Nov-2010

References: Bauer, L. Personal communication, 2008-9

\begin{tabular}{|c|c|}
\hline Solution \#: & 3 \\
\hline Use: & $0.25 \mathrm{ml}$ into each tube at stage 1 of in vitro fermentation. \\
\hline Equipment: & $\begin{array}{l}100 \mathrm{ml} \text { amber volumetric flask } \\
\text { Scale } \\
3 \times 3 \text { Weigh paper } \\
\text { Small metal scoop } \\
\text { Gloves } \\
\text { Dust mask } \\
\text { Silicone stopper to fit } 100 \mathrm{ml} \text { volumetric flask }\end{array}$ \\
\hline Reagents: & $\begin{array}{l}0.5 \mathrm{~g} \text { Chloramphenicol CAS 56-75-7 } \\
\text { 95\% Ethanol }\end{array}$ \\
\hline Procedure: & $\begin{array}{l}\text { 1. Wearing gloves and the dust mask weigh the chloramphenicol } \\
\text { onto the weigh paper and add to the } 100 \mathrm{ml} \text { flask. } \\
\text { 2. Add approximately } 50 \mathrm{ml} 95 \% \text { ethanol to the } 100 \mathrm{ml} \text { flask and } \\
\text { mix well. } \\
\text { 3. Add } 95 \% \text { ethanol to the } 100 \mathrm{ml} \text { flask until the volume reads } \\
100 \mathrm{ml} \text {. }\end{array}$ \\
\hline Storage: & $\begin{array}{l}\text { Light sensitive. } \\
\text { Label the flask with the solution name, date, preparer's initials, and } \\
\text { time. }\end{array}$ \\
\hline Expiration: & Unknown \\
\hline
\end{tabular}


Appendix G. Sodium Hydroxide Solution.

Animal Science Department

Policies and Procedures

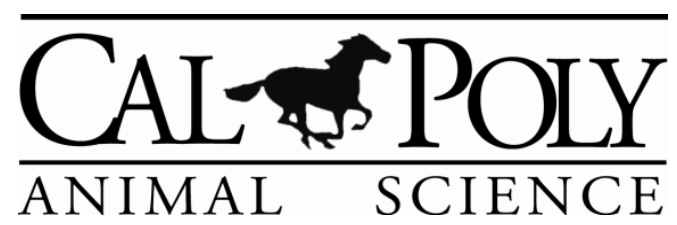

Title Sodium Hydroxide Solution 0.5M

Owner Cassandra Sweeney

Approval Mark S. Edwards, Ph.D., Associate Professor

Revision Level 5

Revision Date 11-Jan-2011

References: Bauer, L. Personal communication, 2008-9

\begin{tabular}{|c|c|}
\hline Solution \#: & 4 \\
\hline Use: & Approximately $4 \mathrm{ml}$ into each tube at stage 2 of in vitro fermentation. \\
\hline Equipment: & $\begin{array}{l}1 \text { liter volumetric flask } \\
\text { Scale } \\
\text { Weigh boat } \\
\text { Small metal scoop } \\
\text { Magnetic stir bar } \\
\text { Stir plate } \\
\text { Magnetic wand } \\
\text { Gloves } \\
\text { Goggles } \\
\text { Silicone stopper to fit } 1 \text { liter volumetric flask }\end{array}$ \\
\hline Reagents: & $\begin{array}{l}20 \mathrm{~g} \text { Sodium Hydroxide Pellets 1310-73-2 } \\
\text { Distilled Water }\end{array}$ \\
\hline Procedure: & $\begin{array}{l}\text { 1. Add approximately } 500 \mathrm{ml} \text { distilled water to the } 1 \text { liter flask. } \\
\text { 2. Place the stir bar in the } 1 \text { liter flask. } \\
\text { 3. Place the flask on the stir plate and gently stir while slowly } \\
\text { adding the sodium hydroxide. } \\
\text { 4. Mix until the sodium hydroxide is completely dissolved. } \\
\text { 5. Remove the stir bar using the magnetic wand. } \\
\text { 6. Add distilled water to the } 1 \text { liter flask until the volume reads } 1 \\
\text { liter, mix well. }\end{array}$ \\
\hline Storage: & $\begin{array}{l}\text { Label the flask with the solution name, date, preparer's initials, and } \\
\text { time. } \\
\text { Seal the flask with the silicone stopper and store in the refrigerator. }\end{array}$ \\
\hline Expiration: & Unknown \\
\hline
\end{tabular}


Appendix H. Pancreatin Phosphate Buffer.

Animal Science Department

Policies and Procedures

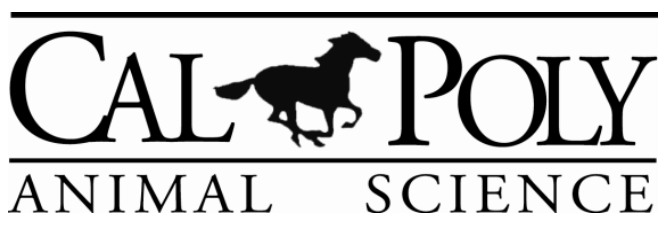

Title Pancreatin Phosphate Buffer $200 \mathrm{ml}$

Owner Cassandra Sweeney

Approval Mark S. Edwards, Ph.D., Associate Professor

Revision Level 3

Revision Date 29-April-2010

References: Bauer, L. Personal communication, 2008-9

\begin{tabular}{|c|c|}
\hline Solution \#: & 5 \\
\hline Use: & $5 \mathrm{ml}$ into each tube at stage 2 of in vitro fermentation. \\
\hline Equipment: & $\begin{array}{l}200 \mathrm{ml} \text { beaker (2) } \\
100 \mathrm{ml} \text { graduated cylinder } \\
50 \mathrm{ml} \text { conical bottom centrifuge tubes with lids } \\
\text { Magnetic stir bar } \\
\text { Stir plate } \\
\text { Scale } \\
\text { pH Meter } \\
3 \times 3 \text { Weigh paper } \\
\text { Small metal scoop } \\
\text { Kimwipes } \\
\text { Parafilm to cover } 200 \mathrm{ml} \text { beaker }\end{array}$ \\
\hline Reagents: & $\begin{array}{ll}3.3 \mathrm{~g} & \text { Sodium Phosphate Dibasic, Anhydrous CAS 7558-79-4 } \\
2.312 \mathrm{~g} \text { Sodium Phosphate Monobasic, Monohydrate CAS 10049-215 } \\
1 \mathrm{~g} \quad \text { Porcine Pancreatin CAS 8049-47-6 } \\
& \text { Distilled Water }\end{array}$ \\
\hline Procedue: & $\begin{array}{l}\text { 1. Rinse the metal scoop with distilled water and dry with } \\
\text { Kimwipes before using on each reagent. } \\
\text { 2. Weigh the sodium phosphate dibasic, anhydrous onto the } \\
\text { weigh paper and add to the } 200 \mathrm{ml} \text { beaker. } \\
\text { 3. Weigh the sodium phosphate monobasic, monohydrate onto } \\
\text { the weigh paper and add to the } 200 \mathrm{ml} \text { beaker. } \\
\text { 4. Add } 200 \mathrm{ml} \text { distilled water to the } 200 \mathrm{ml} \text { beaker, using the } \\
\text { graduated cylinder. } \\
\text { 5. Add the stir bar to the } 200 \mathrm{ml} \text { beaker. } \\
\text { 6. Place the beaker on the stir plate and stir until all reagents are } \\
\text { completely dissolved. } \\
\text { 7. Check the pH, target (6.8 - variation is unacceptable). }\end{array}$ \\
\hline
\end{tabular}




\begin{tabular}{|l|l|}
\hline Procedure & $\begin{array}{r}\text { 8. } \begin{array}{l}\text { Seal the beaker with parafilm and store in the refrigerator until } \\
\text { use. On the day of use weigh the pancreatin onto the weigh } \\
\text { paper and add to the } 200 \mathrm{ml} \text { beaker. } \\
\text { Place on the stir place and mix gently until the pancreatin is } \\
\text { dissolved. }\end{array} \\
\text { 10. Transfer to } 50 \mathrm{ml} \text { tubes, seal, and store until ready to use. } \\
\text { 11. Centrifuge in } 50 \mathrm{ml} \text { tubes at } 1800 \text { RCF for } 10 \text { minutes just } \\
\text { before use. }\end{array}$ \\
$\begin{array}{l}\text { 12. Pour supernate into a clean } 200 \mathrm{ml} \text { beaker and store until } \\
\text { ready to use. }\end{array}$ \\
\hline Storage: & $\begin{array}{l}\text { Label the beaker with the solution name, date, preparer's initials, and } \\
\text { time. } \\
\text { Seal the } 200 \text { ml beaker with Parafilm and store in the refrigerator. } \\
\text { Label } 50 \text { ml tubes with the solution name, date, preparer's initials, and }\end{array}$ \\
\hline Expiration: & $\begin{array}{l}\text { Buffer portion- } 48 \text { hrs after mixing } \\
\text { With pancreatin- day of mixing }\end{array}$ \\
\hline
\end{tabular}


Appendix I. Mineral Solution A.

Animal Science Department

Policies and Procedures

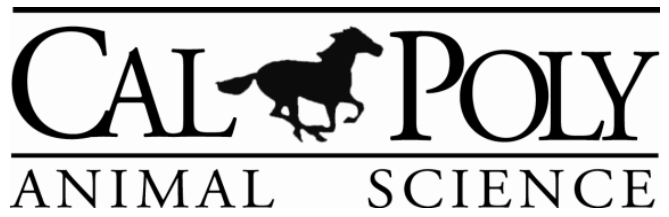

Title Mineral Solution A

Owner Cassandra Sweeney

Approval Mark S. Edwards, Ph.D., Associate Professor

Revision Level 2

Revision Date 16-Aug-2010

References: $\quad$ Bauer, L. Personal communication, 2008-9

\begin{tabular}{|c|c|}
\hline Solution \#: & 6 \\
\hline Use: & $330 \mathrm{ml}$ into the media for in vitro fermentation. \\
\hline Equipment: & $\begin{array}{l}1 \text { liter volumetric flask } \\
1 \text { liter Pyrex jar with lid } \\
\text { Scale } \\
\text { Magnetic stir bar } \\
\text { Stir plate } \\
3 \times 3 \text { Weigh paper } \\
\text { Small metal scoop } \\
\text { Kimwipes }\end{array}$ \\
\hline Reagents: & $\begin{array}{l}5.4 \mathrm{~g} \text { Sodium Chloride CAS 7647-14-5 } \\
2.7 \mathrm{~g} \text { Potassium Phosphate Monobasic Anhydrous CAS 7778-77-0 } \\
0.18 \mathrm{~g} \text { Calcium Chloride Dihydrate CAS } 10035-04-8 \\
0.12 \mathrm{~g} \text { Magnesium Chloride Hexahydrate CAS 7791-18-6 } \\
0.06 \mathrm{~g} \text { Manganese Chloride Tetrahydrate CAS 13446-34-9 } \\
0.06 \mathrm{~g} \text { Cobalt Chloride Hexahydrate CAS 7791-13-1 } \\
5.4 \mathrm{~g} \text { Ammonium Sulfate CAS 7783-20-2 } \\
\quad \text { Distilled Water }\end{array}$ \\
\hline Procedure: & $\begin{array}{l}\text { 1. Rinse the metal scoop with distilled water and dry with } \\
\text { Kimwipes before using on each reagent. } \\
\text { 2. Weigh each reagent onto the weigh paper and add to the } 1 \\
\text { liter flask successively. } \\
\text { 3. Add approximately } 500 \mathrm{ml} \text { distilled water to the } 1 \text { liter flask and } \\
\text { mix until all reagents are completely dissolved. } \\
\text { 4. Add distilled water to the } 1 \text { liter flask until the volume reads } 1 \\
\text { liter. } \\
\text { 5. Add the stir bar to the } 1 \text { liter flask and place on the stir plate } \\
\text { and mix well. } \\
\text { 6. Transfer the solution to the } 1 \text { liter Pyrex jar. }\end{array}$ \\
\hline
\end{tabular}




\begin{tabular}{|l|l|}
\hline Storage: & $\begin{array}{l}\text { Label the jar with the solution name, date, preparer's initials, and } \\
\text { time. } \\
\text { Seal the jar and store in the refrigerator. }\end{array}$ \\
\hline Expiration: & Unknown, Stable \\
\hline
\end{tabular}


Appendix J. Mineral Solution B.

Animal Science Department

Policies and Procedures

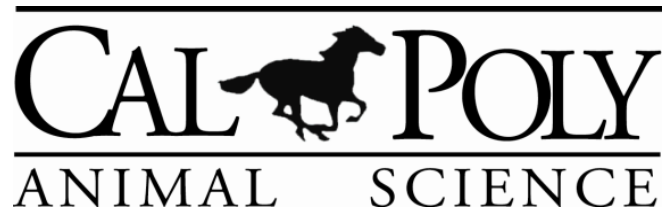

Title Mineral Solution B

Owner Cassandra Sweeney

Approval Mark S. Edwards, Ph.D., Associate Professor

Revision Level 2

Revision Date 26-Oct-2010

References: Bauer, L. Personal communication, 2008-9

\begin{tabular}{|c|c|}
\hline Solution \#: & 7 \\
\hline Use: & $330 \mathrm{ml}$ into the media for in vitro fermentation. \\
\hline Equipment: & $\begin{array}{l}1 \text { liter volumetric flask } \\
1 \text { liter Pyrex jar with lid } \\
\text { Magnetic stir bar } \\
\text { Stir plate } \\
\text { Scale } \\
3 \times 3 \text { Weigh paper } \\
\text { Small metal scoop }\end{array}$ \\
\hline Reagents: & $\begin{array}{l}2.7 \text { g Potassium Phosphate Dibasic Anhydrous CAS 7758-11-4 } \\
\text { Distilled Water }\end{array}$ \\
\hline Procedure: & $\begin{array}{l}\text { 1. Weigh the potassium phosphate dibasic anhydrous onto the } \\
\text { weigh paper and add to the } 1 \text { liter flask. } \\
\text { 2. Add distilled water to the } 1 \text { liter flask until the volume reads } 1 \\
\text { liter. } \\
\text { 3. Add the stir bar to the } 1 \text { liter flask and place on the stir plate } \\
\text { and mix well. } \\
\text { 4. Transfer the solution to the } 1 \text { liter Pyrex jar. }\end{array}$ \\
\hline Storage: & $\begin{array}{l}\text { Label the jar with the solution name, date, preparer's initials, and time. } \\
\text { Seal the jar and store in the refrigerator. }\end{array}$ \\
\hline Expiration: & $48 \mathrm{hrs}$ after mixing \\
\hline
\end{tabular}


Appendix K. Trace Mineral Solution.

Animal Science Department

Policies and Procedures

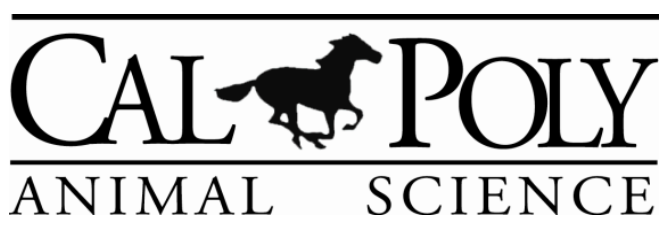

Title Trace Mineral Solution

Owner Cassandra Sweeney

Approval Mark S. Edwards, Ph.D., Associate Professor

Revision Level 3

Revision Date 26-Oct-2010

References: Bauer, L. Personal communication, 2008-9

\begin{tabular}{|c|c|}
\hline Solution \#: & 8 \\
\hline Use: & $10 \mathrm{ml}$ into the media for in vitro fermentation. \\
\hline Equipment: & $\begin{array}{l}1 \text { liter volumetric flask } \\
\text { Scale } \\
3 \times 3 \text { Weigh paper or small weigh boats } \\
\text { Small metal scoop } \\
\text { Magnetic stir bar } \\
\text { Magnetic wand } \\
\text { Stir plate } \\
2-20 \mu l \text { pipette } \\
1-20 \mu l \text { pipette tips } \\
10 \text { ml pipette } \\
\text { Kimwipes } \\
\text { Silicone stopper to fit } 1 \text { liter volumetric flask }\end{array}$ \\
\hline Reagents: & $\begin{array}{l}0.5 \mathrm{~g} \text { EDTA (disodium salt) CAS 60-00-4 } \\
0.2 \mathrm{~g} \quad \text { Ferrous Sulfate Heptahydrate CAS 7782-63-0 } \\
0.01 \mathrm{~g} \text { Zinc Sulfate Heptahydrate CAS 7446-20-0 } \\
0.003 \mathrm{~g} \text { Manganese Chloride Tetrahydrate CAS 13446-34-9 } \\
0.03 \mathrm{~g} \quad(18 \mu \mathrm{ll}) \text { Phosphoric Acid CAS 7664-38-2 } \\
0.02 \mathrm{~g} \text { Cobalt Chloride Hexahydrate CAS 7791-13-1 } \\
0.001 \mathrm{~g} \text { Cupic Chloride Dihydrate CAS 10125-13-0 } \\
0.002 \mathrm{~g} \text { Nickelous Chloride Hexahydrate CAS 7791-20-0 } \\
0.003 \mathrm{~g} \text { Sodium Molybdate Dihydrate CAS 10102-40-6 } \\
\quad \text { Sodium Hydroxide Solution 1M } \\
\quad \text { Distilled Water }\end{array}$ \\
\hline Procedure: & $\begin{array}{l}\text { 1. Add approximately } 400 \mathrm{ml} \text { distilled water to the } 1 \text { liter flask. } \\
\text { 2. Add the EDTA to the } 1 \text { liter flask. } \\
\text { 3. Add the stir bar to the } 1 \text { liter flask and place on the stir plate, } \\
\text { begin stirring. }\end{array}$ \\
\hline
\end{tabular}




\begin{tabular}{|l|l|}
\hline $\begin{array}{l}\text { Procedure } \\
\text { cont.: }\end{array}$ & $\begin{array}{l}\text { 4. Using the } 10 \mathrm{ml} \text { pipette, add } 1 \text { drop Sodium Hydroxide } \\
\text { Solution (1M) at a time to the } 1 \text { liter flask, about every 5-10 } \\
\text { minutes until the EDTA is completely dissolved. }\end{array}$ \\
& $\begin{array}{l}\text { 5. Remove the stir bar with the magnetic wand. } \\
\text { 6. } \begin{array}{l}\text { Rinse the metal scoop with distilled water and dry with } \\
\text { Kimwipes before using on each reagent. } \\
\text { 7. Weigh each remaining reagent onto the weigh paper and add } \\
\text { to the } 1 \text { liter flask successively. }\end{array} \\
\text { 8. Add distilled water to the flask until the volume reads } 1 \text { liter. }\end{array}$ \\
\hline Storage: & $\begin{array}{l}\text { Label the flask with the solution name, date, preparer's initials, and } \\
\text { time. } \\
\text { Seal the flask with the silicone stopper and store in the refrigerator. }\end{array}$ \\
\hline Expiration: & \begin{tabular}{l} 
Unknown, Stable \\
\hline
\end{tabular}
\end{tabular}


Appendix L. Water Soluble Vitamin Solution.

Animal Science Department

Policies and Procedures



Title Water Soluble Vitamin Solution

Owner Cassandra Sweeney

Approval Mark S. Edwards, Ph.D., Associate Professor

Revision Level 3

Revision Date 29-March-2012

References: Bauer, L. Personal communication, 2008-9

\begin{tabular}{|c|c|}
\hline Solution \#: & 9 \\
\hline Use: & $20 \mathrm{ml}$ into the media for in vitro fermentation. \\
\hline Equipment: & $\begin{array}{l}1 \text { liter volumetric flask } \\
1 \text { liter Pyrex jar with lid } \\
\text { Scale } \\
3 \times 3 \text { Weigh paper } \\
\text { Small metal scoop } \\
10 \mathrm{ml} \text { or larger pipette } \\
10 \mathrm{ml} \text { pipette tips } \\
\text { Kimwipes } \\
\text { Silicone stopper to fit } 1 \text { liter volumetric flask } \\
\text { Tin Foil }\end{array}$ \\
\hline Reagents: & $\begin{array}{ll}0.1 \mathrm{~g} & \text { Thiamin } \mathrm{HCl} 67-03-8 \\
0.01 \mathrm{~g} & \text { Panthothenic Acid 137-08-6 } \\
0.1 \mathrm{~g} & \text { Niacin 59-67-6 } \\
0.1 \mathrm{~g} & \text { Pyridoxine 65-23-6 } \\
0.005 \mathrm{~g} & \text { P-Aminobenzoic Acid 150-13-0 } \\
10 \mathrm{ml} & \text { Vitamin B-12 Solution } \\
& \text { Distilled Water }\end{array}$ \\
\hline Procedure: & $\begin{array}{l}\text { 1. Rinse the metal scoop with distilled water and dry with } \\
\text { Kimwipes before using on each reagent. } \\
\text { 2. Weigh each reagent onto the weigh paper and add to the } 1 \\
\text { liter flask successively. } \\
\text { 3. Add approximately } 500 \mathrm{ml} \text { distilled water to the } 1 \text { liter flask and } \\
\text { mix until all reagents are completely dissolved. } \\
\text { 4. Add the Vitamin B-12 Solution to the } 1 \text { liter flask and mix. } \\
\text { 5. Add distilled water to the } 1 \text { liter flask until the volume reads } 1 \\
\text { liter. }\end{array}$ \\
\hline
\end{tabular}




\begin{tabular}{|l|l|}
\hline Storage: & $\begin{array}{l}\text { Light sensative. } \\
\text { Seal the jar and cover with tin foil. Label the flask with the solution } \\
\text { name, date, preparer's initials, and time, store in the refrigerator. }\end{array}$ \\
\hline Expiration: & Unknown, Stable \\
\hline
\end{tabular}


Appendix M. Vitamin B-12 Solution.

Animal Science Department

Policies and Procedures

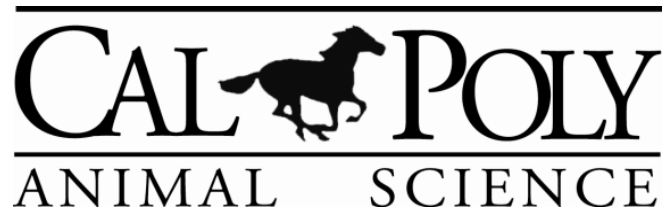

Title Vitamin B-12 Solution

Owner Cassandra Sweeney

Approval Mark S. Edwards, Ph.D., Associate Professor

Revision Level 1

Revision Date 01-Jan-2010

References: Bauer, L. Personal communication, 2008-9

\begin{tabular}{|c|c|}
\hline Solution \#: & $9 A$ \\
\hline Use: & $10 \mathrm{ml}$ into the water soluble vitamin solution for in vitro fermentation. \\
\hline Equipment: & $\begin{array}{l}100 \mathrm{ml} \text { amber volumetric flask } \\
\text { Scale } \\
3 \times 3 \text { Weigh paper } \\
\text { Small metal scoop } \\
\text { Silicone stopper to fit } 100 \mathrm{ml} \text { volumetric flask }\end{array}$ \\
\hline Reagents: & $\begin{array}{c}0.0025 \text { g Vitamin B-12 CAS 68-19-9 } \\
\text { Distilled Water }\end{array}$ \\
\hline Procedure: & $\begin{array}{l}\text { 1. Weigh the vitamin } \mathrm{B}-12 \text { onto the weigh paper and add to the } \\
100 \mathrm{ml} \text { flask. You may need to rinse the weigh paper with } \\
\text { distilled water to get all the vitamin B-12 into the flask. } \\
\text { 2. Add approximately } 50 \mathrm{ml} \text { distilled water to the } 100 \mathrm{ml} \text { flask and } \\
\text { mix well. } \\
\text { 3. Add distilled water to the } 100 \mathrm{ml} \text { flask until the volume reads } \\
100 \mathrm{ml} \text {. }\end{array}$ \\
\hline Storage: & $\begin{array}{l}\text { Light Sensative. } \\
\text { Label the flask with the solution name, date, preparer's initials, and } \\
\text { time. Seal the flask with the silicone stopper and store in the } \\
\text { refrigerator. }\end{array}$ \\
\hline Expiration: & Unknown \\
\hline
\end{tabular}


Appendix N. Folate-Biotin Solution.

Animal Science Department

Policies and Procedures

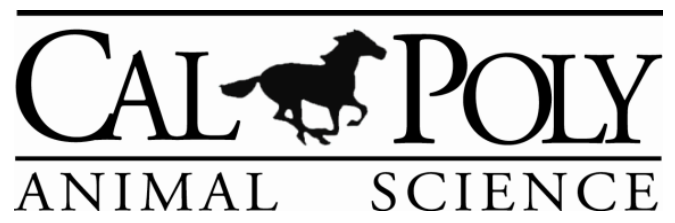

Title Folate-Biotin Solution

Owner Cassandra Sweeney

Approval Mark S. Edwards, Ph.D., Associate Professor

Revision Level 2

Revision Date 19-May-2010

References: Bauer, L. Personal communication, 2008-9

\begin{tabular}{|l|l|}
\hline Solution \#: & 10 \\
\hline Use: & $5 \mathrm{ml}$ into the media for in vitro fermentation. \\
\hline Equipment: & $\begin{array}{l}1 \text { liter volumetric flask } \\
1 \text { liter Pyrex jar with lid } \\
\text { Scale } \\
\text { 3x3 Weigh paper } \\
\text { Small metal scoop } \\
\text { Kimwipes } \\
\text { Tin Foil }\end{array}$ \\
\hline Reagents: & $\begin{array}{l}0.01 \mathrm{~g} \text { Folic acid CAS 59-30-3 } \\
0.002 \mathrm{~g} \text { Biotin CAS 58-85-5 } \\
\text { Ammonium Carbonate CAS 506-87-6 } \\
\text { Distilled Water }\end{array}$ \\
\hline Procedure: & $\begin{array}{l}\text { 1. } \begin{array}{l}\text { Rinse the metal scoop with distilled water and dry with } \\
\text { Kimwipes before using on each reagent. } \\
\text { 2. Weigh each reagent with the weigh paper and add to the 1 } \\
\text { liter flask successively. } \\
\text { 3. Add approximately 500 ml distilled water to the 1 liter flask } \\
\text { and mix until all the reagents are completely dissolved. }\end{array} \\
\text { 4. Add distilled water to the 1 liter flask until the volume reads 1 } \\
\text { liter. }\end{array}$ \\
\hline Storage: & $\begin{array}{l}\text { Seal the jar and cover with tin foil. Label the jar with the solution } \\
\text { name, date, preparer's initials, and time, store in the refrigerator. }\end{array}$ \\
\hline Expiration: & \begin{tabular}{l} 
Unknown, Stable \\
\hline
\end{tabular}
\end{tabular}


Appendix O. Riboflavin Solution.

Animal Science Department

Policies and Procedures

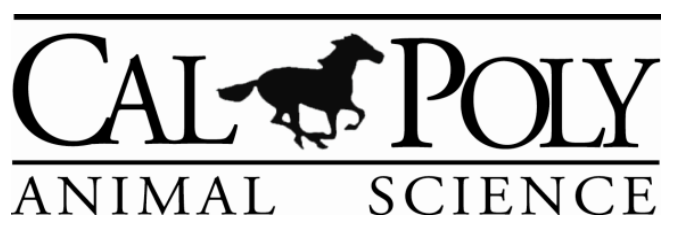

Title Riboflavin Solution

Owner Cassandra Sweeney

Approval Mark S. Edwards, Ph.D., Associate Professor

Revision Level 3

Revision Date 19-May-2010

References: Bauer, L. Personal communication, 2008-9

\begin{tabular}{|c|c|}
\hline Solution \#: & 11 \\
\hline Use: & $5 \mathrm{ml}$ into the media for in vitro fermentation. \\
\hline Equipment: & $\begin{array}{l}100 \mathrm{ml} \text { amber volumetric flask } \\
\text { Scale } \\
3 \times 3 \text { Weigh paper } \\
\text { Small metal scoop } \\
\text { Silicone stopper to fit } 100 \mathrm{ml} \text { volumetric flask } \\
\text { Kimwipes }\end{array}$ \\
\hline Reagents: & $\begin{array}{l}0.001 \text { g Riboflavin CAS 83-88-5 } \\
0.13 \text { g HEPES CAS 7365-45-9 } \\
\text { Distilled Water }\end{array}$ \\
\hline Procedure: & $\begin{array}{l}\text { 1. Rinse the metal scoop with distilled water and dry with } \\
\text { Kimwipes before using on each reagent. } \\
\text { 2. Weigh each reagent onto the weigh paper and add to the } 100 \\
\text { ml flask successively. } \\
\text { 3. Add approximately } 50 \mathrm{ml} \text { distilled water to the } 100 \mathrm{ml} \text { flask } \\
\text { and mix until all reagents are completely dissolved. } \\
\text { 4. Add distilled water to the } 100 \mathrm{ml} \text { flask until the volume reads } \\
100 \mathrm{ml} \text {. }\end{array}$ \\
\hline Storage: & $\begin{array}{l}\text { Label the flask with the solution name, date, preparer's initials, and } \\
\text { time. } \\
\text { Seal the flask with the silicone stopper and store in the refrigerator. }\end{array}$ \\
\hline Expiration: & Unknown \\
\hline
\end{tabular}


Appendix P. Hemin Solution.

Animal Science Department

Policies and Procedures

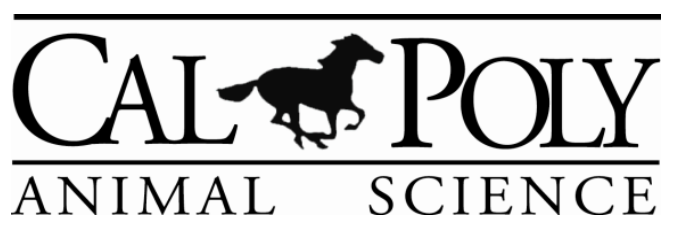

Title Hemin Solution

Owner Cassandra Sweeney

Approval Mark S. Edwards, Ph.D., Associate Professor

Revision Level 3

Revision Date 19-May-2010

References: Bauer, L. Personal communication, 2008-9

\begin{tabular}{|c|c|}
\hline Solution \#: & 12 \\
\hline Use: & $5 \mathrm{ml}$ into the media for in vitro fermentation. \\
\hline Equipment: & $\begin{array}{l}100 \mathrm{ml} \text { amber volumetric flask } \\
\text { Scale } \\
3 \times 3 \text { Weigh paper } \\
\text { Small metal scoop } \\
\text { Silicone stopper to fit } 100 \mathrm{ml} \text { volumetric flask } \\
\text { Kimwipes }\end{array}$ \\
\hline Reagents: & $\begin{array}{l}0.05 \mathrm{~g} \text { Hemin CAS } 16009-13-5 \\
0.04 \mathrm{~g} \text { Sodium Hydroxide CAS 1310-73-2 } \\
\text { Distilled Water }\end{array}$ \\
\hline Procedure: & $\begin{array}{l}\text { 1. Rinse the metal scoop with distilled water and dry with } \\
\text { Kimwipes before using on each reagent. } \\
\text { 2. Weigh each reagent onto the weigh paper and add to the } 100 \\
\text { ml flask successively. } \\
\text { 3. Add approximately } 50 \mathrm{ml} \text { distilled water to the } 100 \mathrm{ml} \text { flask } \\
\text { and mix until all reagents are completely dissolved. } \\
\text { 4. Add distilled water to the } 100 \mathrm{ml} \text { flask until the volume reads } \\
100 \mathrm{ml} \text {. }\end{array}$ \\
\hline Storage: & $\begin{array}{l}\text { Label the flask with the solution name, date, preparer's initials, and } \\
\text { time. } \\
\text { Seal the flask with the silicone stopper and store in the refrigerator. }\end{array}$ \\
\hline Expiration: & $\mathrm{W}$ \\
\hline
\end{tabular}


Appendix Q. Short Chain Fatty Acid Mix.

Animal Science Department

Policies and Procedures

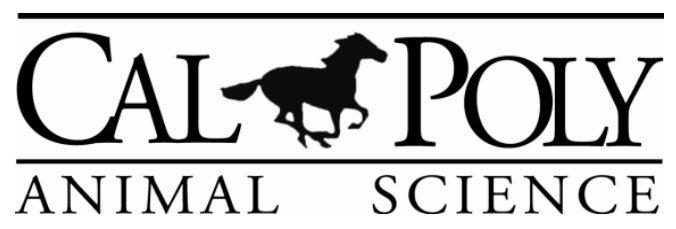

Title Short Chain Fatty Acid Mix

Owner Cassandra Sweeney

Approval Mark S. Edwards, Ph.D., Associate Professor

Revision Level 1

Revision Date 19-May-2010

References: Bauer, L. Personal communication, 2008-9

\begin{tabular}{|c|c|}
\hline Solution \#: & 13 \\
\hline Use: & $0.4 \mathrm{ml}$ into the media for in vitro fermentation. \\
\hline Equipment: & $\begin{array}{l}25 \times 95 \mathrm{~mm} \text { glass vial (or other small glass vial) } \\
100-1000 \mu \mathrm{L} \text { pipette } \\
1000 \mu \mathrm{L} \text { pipette tips }\end{array}$ \\
\hline Reagents: & $\begin{array}{l}\text { N-valerate CAS 109-52-4 } \\
\text { Isovalerate CAS 503-74-2 } \\
\text { Isobutyrate CAS 79-31-2 } \\
\text { DL-2-Methylbutyrate CAS 116-53-0 }\end{array}$ \\
\hline Procedure: & $\begin{array}{l}\text { 1. Pipette } 150 \mu \mathrm{L} \text { of each reagent into the glass vial, using a new } \\
\text { pipette tip for each reagent. } \\
\text { 2. Mix to combine reagents. }\end{array}$ \\
\hline Storage: & None \\
\hline Expiration: & Use immediately \\
\hline
\end{tabular}


Appendix R. Resazurin Solution $0.1 \%$.

Animal Science Department

Policies and Procedures

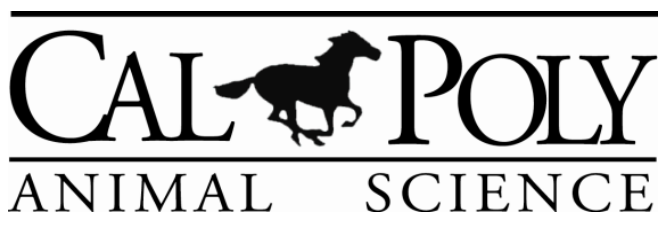

Title $\quad$ Resazurin Solution $0.1 \%$

Owner Cassandra Sweeney

Approval Mark S. Edwards, Ph.D., Associate Professor

Revision Level 2

Revision Date 29-Jan-2010

References: $\quad$ Bauer, L. Personal communication, 2008-9

\begin{tabular}{|l|l|}
\hline Solution Number: & 14 \\
\hline Use: & $1 \mathrm{ml}$ into the anaerobic diluting solution for in vitro fermentation. \\
\hline Equipment: & $\begin{array}{l}100 \mathrm{ml} \text { amber volumetric flask } \\
\text { Scale } \\
3 \times 3 \text { Weigh paper } \\
\text { Small metal scoop } \\
\text { Silicone stopper to fit } 100 \mathrm{ml} \text { volumetric flask }\end{array}$ \\
\hline Reagents: & $\begin{array}{l}0.1 \mathrm{~g} \text { Resazurin } 0.1 \% \text { CAS } 62758-13-8 \\
\text { Distilled Water }\end{array}$ \\
\hline Procedure: & $\begin{array}{l}\text { 1. Weigh the resazurin onto the weigh paper and add to the } \\
100 \mathrm{ml} \text { flask. } \\
\text { 2. Add approximately } 50 \mathrm{ml} \text { distilled water to the } 100 \mathrm{ml} \\
\text { flask and mix well. } \\
\text { 3. Add distilled water to the 100 ml flask until the volume } \\
\text { reads } 100 \mathrm{ml} .\end{array}$ \\
\hline Storage: & $\begin{array}{l}\text { Label the flask with the solution name, date, preparer's initials, } \\
\text { and time. } \\
\text { Seal the flask with the silicone stopper and store in the } \\
\text { refrigerator. }\end{array}$ \\
\hline Expiration: & \begin{tabular}{l} 
Unknown \\
\hline
\end{tabular} \\
\hline
\end{tabular}


Appendix S. Media.

\section{Animal Science Department}

Policies and Procedures

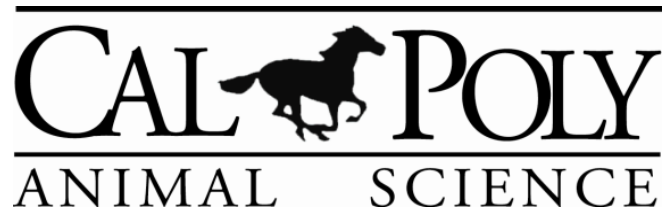

$\begin{array}{ll}\text { Title } & \text { Media } \\ \text { Owner } & \text { Cassandra Sweeney } \\ \text { Approval } & \text { Mark S. Edwards, Ph.D., Associate Professor } \\ \text { Revision Level } & 2 \\ \text { Revision Date } & \text { 29-March-2012 } \\ \text { References: } & \text { Bauer, L. Personal communication, 2008-9 }\end{array}$

Sunvold, G. D., Hussein, H. S., Fahey Jr., G. C., Merchen, N. R. \& Reinhart, G. A. 1995. In vitro fermentation of cellulose, beet pulp, citrus pulp, and citrus pectin using fecal inoculum from cats, dogs, horses, humans, and pigs and ruminal fluid from cattle. Journal of Animal Science, 73, 3639-3648.

\begin{tabular}{|l|l|}
\hline Solution \#: & 15 \\
\hline Use: & $26 \mathrm{ml}$ into each tube for stage 3 of in vitro fermentation. \\
\hline Equipment: & Scale \\
& Autoclave \\
& $\mathrm{CO}_{2}$ gas with appropriate tubing and gassing jets \\
& $250 \mathrm{ml}$ volumetric flask \\
& $100 \mathrm{ml}$ volumetric flask \\
& $2 \mathrm{~L}$ round bottom flask, \#4260 Pyrex \\
& Cork ring to fit $2 \mathrm{~L}$ round bottom flask \\
& $\# 10$ rubber stopper, solid \\
& Wire for sealing flask \\
& $10 \mathrm{ml}$ pipettes \\
& $1000 \mu \mathrm{L}$ pipette tips \\
& $100-1000$ L pipette \\
& $3 \times 3$ Weigh paper \\
& Small metal scoop \\
& $18 \mathrm{gauge}$ needles \\
& $20 \mathrm{ml}$ syringe \\
& $5 \mathrm{ml}$ syringe \\
& $1 \mathrm{ml}$ syringe \\
& Syringe filters
\end{tabular}




\begin{tabular}{|c|c|}
\hline Reagents: & $\begin{array}{l}330 \mathrm{ml} \text { Mineral Solution A } \\
330 \mathrm{ml} \text { Mineral Solution B } \\
10 \mathrm{ml} \text { Trace Mineral Solution } \\
1 \mathrm{ml} \text { Resazurin Solution } \\
0.5 \mathrm{~g} \text { Yeast Extract CAS } 8013-01-2 \\
0.5 \mathrm{~g} \text { Trypticase (BD catalog number 211921) } \\
4 \mathrm{~g} \text { Sodium Carbonate 497-19-8 } \\
0.5 \mathrm{~g} \text { Cysteine HCl Monohydrate CAS 7048-04-6 } \\
0.4 \mathrm{ml} \text { Short Chain Fatty Acid Mix }\end{array}$ \\
\hline $\begin{array}{l}\text { Reagents } \\
\text { cont.: }\end{array}$ & $\begin{array}{l}20 \mathrm{ml} \text { Water Soluble Vitamin Solution } \\
5 \mathrm{ml} \text { Folate:Biotin Solution } \\
5 \mathrm{ml} \text { Riboflavin Solution } \\
5 \mathrm{ml} \text { Hemin Solution } \\
296 \mathrm{ml} \text { Distilled Water }\end{array}$ \\
\hline Procedure: & 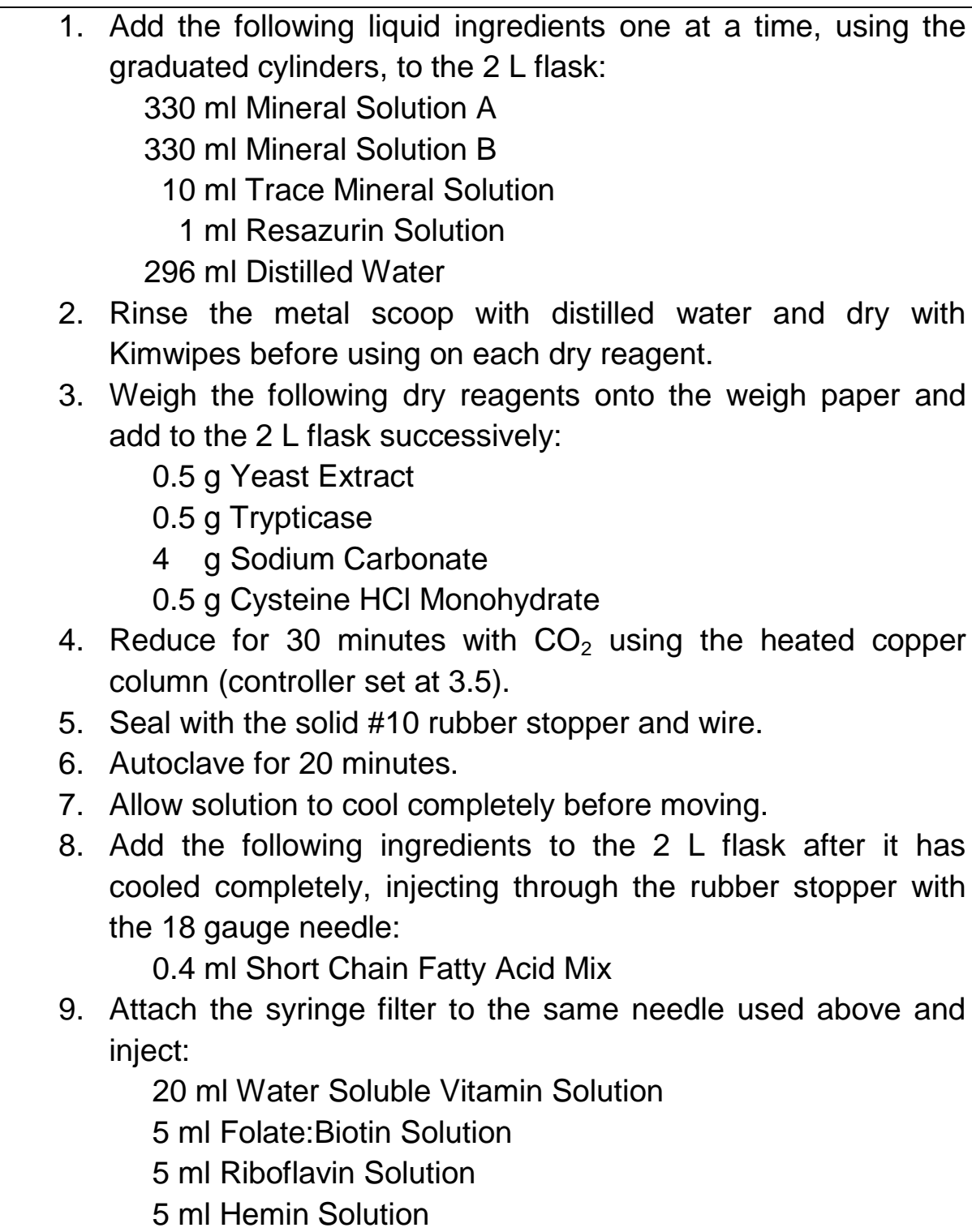 \\
\hline
\end{tabular}




\begin{tabular}{|l|l|}
\hline Storage: & $\begin{array}{l}\text { Label the flask with the solution name, date, preparer's initials, and } \\
\text { time. } \\
\text { Seal the flask the silicone stopper and store in the refrigerator. }\end{array}$ \\
\hline Expiration: & $\begin{array}{l}\text { Unknown before adding final reagents, day of use after adding final } \\
\text { reagents. }\end{array}$ \\
\hline
\end{tabular}


Appendix T. Mineral Solution 1.

Animal Science Department

Policies and Procedures



Title Mineral Solution 1

Owner Cassandra Sweeney

Approval Mark S. Edwards, Ph.D., Associate Professor

Revision Level 3

Revision Date 19-May-2010

References: Bauer, L. Personal communication, 2008-9

\begin{tabular}{|c|c|}
\hline Solution \#: & 16 \\
\hline Use: & $37.5 \mathrm{ml}$ into the anaerobic dilution solution for in vitro fermentation. \\
\hline Equipment: & $\begin{array}{l}500 \mathrm{ml} \text { volumetric flask } \\
\text { Scale } \\
3 \times 3 \text { Weigh paper } \\
\text { Small metal scoop } \\
\text { Silicone stopper to fit } 500 \mathrm{ml} \text { volumetric flask } \\
\text { Kimwipes }\end{array}$ \\
\hline Reagents: & $\begin{array}{ll}3 \mathrm{~g} & \text { Potassium Phosphate Dibasic, Anhydrous CAS 7758-11-4 } \\
1 \mathrm{~g} & \text { Sodium Citrate Dihydrate CAS 6132-04-3 } \\
& \text { Distilled Water }\end{array}$ \\
\hline Procedure: & $\begin{array}{l}\text { 1. Rinse the metal scoop with distilled water and dry with } \\
\text { Kimwipes before using on each reagent. } \\
\text { 2. Weigh each reagent onto the weigh paper and add to the } 500 \\
\text { ml flask successively. } \\
\text { 3. Add approximately } 250 \mathrm{ml} \text { distilled water to the } 500 \mathrm{ml} \text { flask } \\
\text { and mix until all reagents are completely dissolved. } \\
\text { 4. Add distilled water to the } 500 \mathrm{ml} \text { flask until the volume reads } \\
500 \mathrm{ml} \text {. }\end{array}$ \\
\hline Storage: & $\begin{array}{l}\text { Label the flask with the solution name, date, preparer's initials, and } \\
\text { time. } \\
\text { Seal the flask the silicone stopper and store in the refrigerator. }\end{array}$ \\
\hline Expiration: & Unknown, Stable \\
\hline
\end{tabular}


Appendix U. Mineral Solution 2.

Animal Science Department

Policies and Procedures

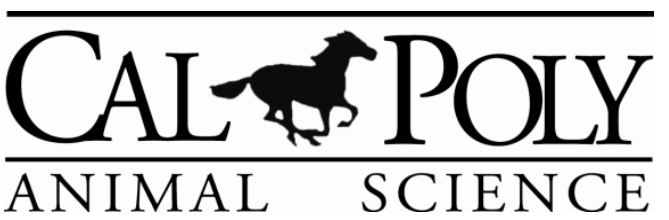

Title Mineral Solution 2

Owner Cassandra Sweeney

Approval Mark S. Edwards, Ph.D., Associate Professor

Revision Level 3

Revision Date 29-April-2010

References: Bauer, L. Personal communication, 2008-9

\begin{tabular}{|c|c|}
\hline Solution \#: & 17 \\
\hline Use: & $37.5 \mathrm{ml}$ into the anaerobic dilution solution for in vitro fermentation. \\
\hline Equipment: & $\begin{array}{l}500 \mathrm{ml} \text { volumetric flask } \\
\text { Scale } \\
3 \times 3 \text { Weigh paper } \\
4 \times 4 \text { Weigh paper } \\
\text { Small metal scoop } \\
\text { Kimwipes } \\
\text { Silicone stopper to fit } 500 \mathrm{ml} \text { volumetric flask }\end{array}$ \\
\hline Reagents: & $\begin{array}{ll}6 \mathrm{~g} & \text { Sodium Chloride CAS 7647-14-5 } \\
6 \mathrm{~g} & \text { Ammonium Sulfate CAS } \underline{7783-20-2} \\
3 \mathrm{~g} & \text { Potassium Phosphate Monobasic, Anhydrous CAS 7778-77-0 } \\
0.6 \mathrm{~g} & \text { Calcium Chloride Dihydrate CAS } \underline{10035-04-8} \\
1.23 \mathrm{~g} & \text { Magnesium Sulfate Heptahydrate CAS 10034-99-8 } \\
10 \mathrm{~g} & \begin{array}{l}\text { Sodium Citrate Dihydrate CAS 6132-04-3 } \\
\text { Distilled Water }\end{array}\end{array}$ \\
\hline Procedure: & $\begin{array}{l}\text { 1. Add approximately } 250 \mathrm{ml} \text { distilled water to the } 500 \mathrm{ml} \text { flask. } \\
\text { 2. Rinse the metal scoop with distilled water and dry with } \\
\text { Kimwipes before using on each reagent. } \\
\text { 3. Weigh each reagent onto the weigh paper and add to the } 500 \\
\text { ml flask successively, dissolving each ingredient before } \\
\text { adding the next. } \\
\text { 4. Add distilled water to the } 500 \mathrm{ml} \text { flask until the volume reads } \\
500 \mathrm{ml} \text {. }\end{array}$ \\
\hline Storage: & $\begin{array}{l}\text { Label the flask with the solution name, date, preparer's initials, and } \\
\text { time. } \\
\text { Seal the flask with the silicone stopper and store in the refrigerator. }\end{array}$ \\
\hline Expiration: & L \\
\hline
\end{tabular}


Appendix V. Sodium Bicarbonate Solution.

\section{Animal Science Department}

Policies and Procedures

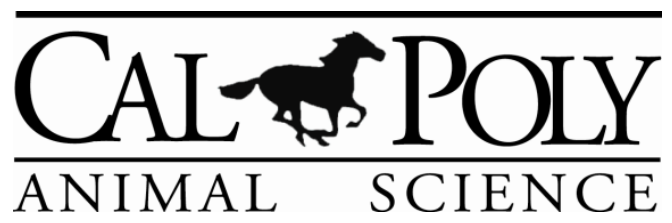

Title Sodium Bicarbonate Solution

Owner Cassandra Sweeney

Approval Mark S. Edwards, Ph.D., Associate Professor

Revision Level 1

Revision Date 09-Nov-2009

References: Bauer, L. Personal communication, 2008-9

\begin{tabular}{|c|c|}
\hline Solution \#: & 18 \\
\hline Use: & $70 \mathrm{ml}$ into the anaerobic dilution solution for in vitro fermentation. \\
\hline Equipment: & $\begin{array}{l}1 \text { liter volumetric flask } \\
1 \text { liter Pyrex jar } \\
100 \text { ml beaker } \\
\text { Small glass funnel } \\
\text { Small metal scoops } \\
\text { Magnetic stir bar } \\
\text { Stir plate } \\
\text { Scale }\end{array}$ \\
\hline Reagents: & $\begin{array}{l}91 \text { g Sodium Bicarbonate CAS 144-55-8 } \\
\text { Distilled Water }\end{array}$ \\
\hline Procedure: & $\begin{array}{l}\text { 1. Weigh the sodium bicarbonate into the } 100 \mathrm{ml} \text { beaker. } \\
\text { 2. Slowly transfer the sodium bicarbonate into the } 1 \text { liter flask } \\
\text { using the funnel. } \\
\text { 3. Add distilled water to the } 1 \text { liter flask until the volume reads } 1 \\
\text { liter, rinsing the funnel as water is added. } \\
\text { 4. Add the stir bar and mix until completely dissolved and } \\
\text { solution is clear. } \\
\text { 5. Remove the magnetic stir bar. } \\
\text { 6. If the volume does not read } 1 \text { liter add the appropriate } \\
\text { amount of distilled water. }\end{array}$ \\
\hline Storage: & $\begin{array}{l}\text { Label the jar with the solution name, date, preparer's initials, and } \\
\text { time. } \\
\text { Seal the jar and store at room temperature. }\end{array}$ \\
\hline Expiration: & Unknown, Stable \\
\hline
\end{tabular}


Appendix W. Anaerobic Dilution Solution.

Animal Science Department

Policies and Procedures

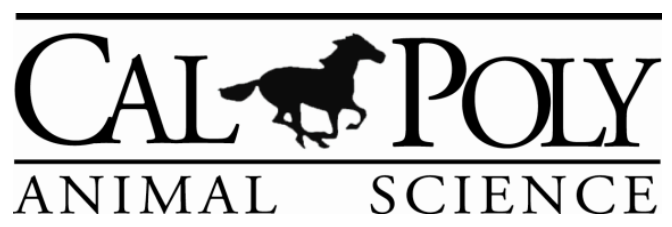

Title Anaerobic Diluting Solution

Owner Cassandra Sweeney

Approval Mark S. Edwards, Ph.D., Associate Professor

Revision Level 3

Revision Date 13-August-2010

References: Bauer, L. Personal communication, 2008-9

\begin{tabular}{|l|l|}
\hline Solution \#: & 19 \\
\hline Use: & To dilute feces for inoculumn preparation for in vitro fermentation. \\
\hline Equipment: & Autoclave \\
& $100 \mathrm{ml}$ glass serum bottles \\
& Rubber serum bottle stoppers \\
& Aluminum serum bottle seals \\
& Crimper for serum bottle seals \\
& Autoclavable plastic tub \\
& $\mathrm{CO}_{2}$ gas with appropriate tubing and gassing jets \\
& Small glass funnel \\
& 1 liter volumetric flask \\
& $10 \mathrm{ml}$ pipettes \\
& $250 \mathrm{ml}$ volumetric flask \\
& $100 \mathrm{ml}$ volumetric flask \\
& $10 \mathrm{ml}$ volumetric flask \\
\hline Reagents: & $37.5 \mathrm{ml}$ Mineral Solution 1 \\
& $37.5 \mathrm{ml}$ Mineral Solution 2 \\
& $1 \mathrm{ml} \quad$ Resazurin Solution \\
& $70 \mathrm{ml}$ Sodium Bicarbonate Solution \\
& $854 \mathrm{ml}$ Distilled Water \\
& $0.5 \mathrm{~g} \quad$ Cysteine HCl Monohydrate CAS 7048-04-6 \\
\hline
\end{tabular}




\begin{tabular}{|l|l|}
\hline Procedure: & $\begin{array}{l}\text { 1. Add Mineral Solution 1, Mineral Solution 2, Resazurin } \\
\text { Solution, and Sodium Bicarbonate Solution to the } 1 \text { liter flask } \\
\text { using the } 10 \mathrm{ml} \text { pipettes (use a new pipette for each reagent). }\end{array}$ \\
& $\begin{array}{l}\text { 2. Add the distilled water to the } 1 \text { liter flask using the graduated } \\
\text { cylinders. }\end{array}$ \\
& $\begin{array}{l}\text { 3. Flush the solution in the } 1 \text { liter flask with } \mathrm{CO}_{2} \text { for } 30 \text { minutes. } \\
\text { 4. Add the Cysteine } \mathrm{HCl} \text { Monohydrate to the } 1 \text { liter flask and } \\
\text { allow to dissolve. }\end{array}$ \\
$\begin{array}{l}\text { 5. Dispense approximately } 90 \mathrm{ml} \text { solution into a serum bottle after } \\
\text { flushing the bottle with } \mathrm{CO}_{2} \text { for two minutes (continue flushing } \\
\text { with } \mathrm{CO}_{2} \text { while filling bottle), seal immediately, repeat } 10 \text { more } \\
\text { times for a total of } 11 \text { bottles. (solution in bottles may remain } \\
\text { light blue, gradually turning clear if solution and bottles have } \\
\text { been properly flushed with } \mathrm{CO}_{2} \text { ). }\end{array}$ \\
$\begin{array}{l}\text { 6. Place serum bottles in the autoclavable tub and autoclave for 20 } \\
\text { minutes on the slow exhaust (liquid) setting. } \\
\text { 7. Allow serum bottles to cool completely before transferring to } \\
\text { storage. Solution must remain clear after autoclaving. }\end{array}$ \\
\hline Storage: & $\begin{array}{l}\text { Label the serum bottles with the solution name, date, time, and } \\
\text { preparer's initials. Store at room temperature. }\end{array}$ \\
\hline Expiration: & Stable as long as solution remains clear. \\
\hline
\end{tabular}


Appendix X. Fecal Inoculumn.

Animal Science Department

Policies and Procedures

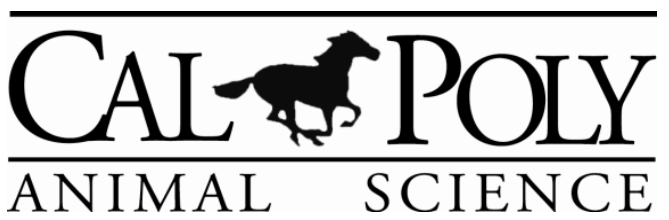

Title Fecal Inoculumn

Owner Cassandra Sweeney

Approval Mark S. Edwards, Ph.D., Associate Professor

Revision Level 2

Revision Date 29-March-2012

References: Bauer, L. Personal communication, 2008-9

\begin{tabular}{|c|c|}
\hline Solution \#: & 20 \\
\hline Use: & $4 \mathrm{ml}$ into each tube for in vitro fermentation \\
\hline Equipment: & $\begin{array}{l}\text { Autoclave } \\
\text { Stainless steel warning blending with small hole in lid, sterile } \\
\text { Scale } \\
250 \mathrm{ml} \text { beaker, sterile } \\
\text { Serum bottles, sterile } \\
\text { Crimper for serum bottle seals } \\
\text { De-crimper for serum bottle seals } \\
\mathrm{CO}_{2} \text { gas with appropriate tubing and gassing jets } \\
\mathrm{Small} \text { metal scoop, sterile } \\
\text { Small funnel, sterile } \\
\text { Cheesecloth } \\
\text { Styrofoam cooler } \\
500 \text { ml Nalgene bottles with lids }\end{array}$ \\
\hline Reagents: & $\begin{array}{l}\text { Anaerobic Diluting Solution } \\
\text { Feces }\end{array}$ \\
\hline Procedure: & $\begin{array}{l}\text { 1. Collect feces and transfer into plastic bags, remove air. } \\
\text { 2. Fill the } 500 \mathrm{ml} \text { Nalgene bottles with very hot water. } \\
\text { 3. Store feces at } 37^{\circ} \mathrm{C} \text { until use, by keeping with the hot water } \\
\text { bottles in the Styrofoam cooler. } \\
\text { 4. Flush the blender with } \mathrm{CO}_{2} \text { before and during blending. } \\
\text { 5. Dilute feces } 1: 10 \text { in anaerobic diluting solution by adding both } \\
\text { reagents into the waring blender quickly (use de-crimper for } \\
\text { serum bottles). } \\
\text { 6. Blend for } 15 \text { seconds. } \\
\text { 7. Line the funnel with four layers of cheesecloth. } \\
\text { 8. Begin flushing serum bottles with } \mathrm{CO}_{2} \text {. } \\
\text { 9. Transfer the liquid from the blender into the serum bottles } \\
\text { using the cheesecloth lined funnel. }\end{array}$ \\
\hline
\end{tabular}




\begin{tabular}{|l|l|}
\hline $\begin{array}{l}\text { Procedure } \\
\text { Cont.: }\end{array}$ & $\begin{array}{l}\text { 10. Cap and seal the serum bottles containing fecal inoculumn. } \\
\begin{array}{l}\text { 11. Keep fecal inoculumn at } 39^{\circ} \mathrm{C} \text { until use by placing serum } \\
\text { bottles in a warm water bath. }\end{array}\end{array}$ \\
\hline Storage: & $\begin{array}{l}\text { Label the serum bottles with the solution name, date, time, and } \\
\text { preparer's initials. Store at room temperature. }\end{array}$ \\
\hline Expiration: & Day of use. \\
\hline
\end{tabular}


Appendix Y. National Forage Testing Association Procedure 2.2.2.2.

\subsubsection{Laboratory Dry Matter by Oven Drying at $100^{\circ} \mathrm{C}$ for $24 \mathrm{hr}$ or $105^{\circ} \mathrm{C}$ for $16 \mathrm{hr}$}

\section{References:}

Moisture in Peat. (967.03) Official Methods of Analysis. 1990. Association of Official Analytical Chemists. 15th Edition.

Faichney, G.J. and G.A. White. 1983. Methods for the analysis of feeds eaten by ruminants. Commonwealth Scientific and Industrial Research Organization, Melbourne, Australia.

Windham, W.R., J.A. Robertson, and R.G. Leffler. 1987. A comparison of methods for moisture determination of forages for near infrared reflectance spectroscopy calibration and validation. Crop Sci. 27:777-783.

Goering, H.K. and P.J. Van Soest. 1970. Forage fiber analyses (apparatus, reagents, procedures, and some applications). ARS/USDA Handbook No. 379 , Superintendent of Documents, US Government Printing Office, Washington, D.C. 20402

\section{Scope:}

This procedure maybe used for determination of laboratory dry matter on ground air-dry or partially dried ( $85 \%$ dry matter) forage samples. This procedure is also applicable for dry weight determinations of fiber residues following acid detergent or neutral detergent extraction.

\section{Basic Principle:}

Moisture is evaporated from the sample by oven drying. Laboratory dry matter is determined gravimetrically as residue remaining after drying.

\section{Equipment:}

Forced-air drying oven at $100 \mathrm{oC}$ (or $105 \mathrm{oC}$ ), capable of maintaining temperature at $\pm 10 \mathrm{C}$. Oven should be equipped with a wire rod shelf to allow the circulation of air. It should be vented and operated with vents open.

Aluminum dish (pan), $50 \mathrm{~mm}$ diameter, $40 \mathrm{~mm}$ deep, covered if desiccator used Crucibles, porcelain, low wide form, $50 \mathrm{~mL}$, Coors \#1, covered if desiccator used Top loading electronic balance, accurate to $0.1 \mathrm{mg}$

Reagents: None. 


\section{Safety Precautions:}

- Use standard precautions when working with electrical equipment or glassware.

- Make sure that all electrical equipment is properly grounded and installed and maintained by qualified electricians.

Procedure: Hot Weigh Method

1. If only moisture is to be determined on the sample, use an aluminum dish. If ash determination is to follow on the dry matter residue, use a porcelain crucible. Dry the appropriate container and three crucibles to be used to warm the balance at $1000 \mathrm{C}$ (or $1050 \mathrm{C}$ ) for at least $2 \mathrm{hr}$.

2. Warm balance by sequentially placing three empty crucibles on balance for 20 sec each.

3. Removing one at a time from the oven, weigh container (W4), recording weight to nearest $0.1 \mathrm{mg}$. Weigh rapidly, recording minimum weight (as soon as balance has stabilized, usually within $15 \mathrm{sec}$ after removing from oven). Whenever weighing is interrupted, balance should be re-warmed according to step (2).

4. After all containers have been weighed, allow balance and sample containers to cool.

5. Tare container to zero and weigh (W7) approximately $2 \mathrm{~g}$ ground sample into each container or weigh approximately $2 \mathrm{~g}$ into each container and record weight of sample and container (W5) to nearest $0.1 \mathrm{mg}$.

6. Shake container gently to uniformly distribute the sample and expose the maximum area for drying.

7. Place samples into an oven which has been preheated to $100 \mathrm{oC}$ (or $105 \mathrm{oC}$ ) for at least $3 \mathrm{hr}$. Oven should return to temperature within $1 \mathrm{hr}$ after samples in containers have been placed into it.

8. Leave uncovered samples in oven for $24 \mathrm{hr}$ at $100 \mathrm{oC}$ or $16 \mathrm{hr}$ (or overnight) at $1050 \mathrm{C}$.

9. Individually remove containers from oven and hot weigh containers with dried sample as described in steps (2) and (3). Record weight (W6) to nearest $0.1 \mathrm{mg}$.

\section{Comments:}

- Use a forced-air oven so that drying is more rapid and uniform and temperature drop is minimized during weighing.

- Samples should be placed in the drying oven so that air can circulate freely. Containers should not touch each other

- The balance must be located next to the oven; carrying samples any distance will allow cooling and addition of moisture.

- Containers should be removed from oven one at a time and immediately weighed. 
- Use of computer software to electronically record weight is recommended to reduce variance in weights due to operator differences in determining minimum weight.

\section{Procedure: Cold Weigh Method}

1. If only moisture is to be determined on the sample, use an aluminum dish with cover. If ash determination is to follow on the dry matter residue, use a porcelain crucible with cover. Dry the appropriate containers at $100 \mathrm{oC}$ (or $105 \mathrm{oC}$ ) for at least $2 \mathrm{hr}$.

2. Cover containers and move to desiccator. Immediately cover desiccator and allow containers to cool to room temperature. Do not allow containers to remain in desiccator more than 2 to $3 \mathrm{hr}$.

3. Weigh container with cover (W4) to nearest $0.1 \mathrm{mg}$, removing one at a time from desiccator and keeping desiccator closed between container removals.

4. Tare container and weigh (W7) approximately $2 \mathrm{~g}$ ground sample into container with cover or add approximately $2 \mathrm{~g}$ ground sample to each container and record weight of container with cover and sample (W5) to nearest $0.1 \mathrm{mg}$.

5. Shake container gently to uniformly distribute the sample and expose the maximum area for drying.

6. Place samples with covers removed to side into oven that has been preheated to $100 \mathrm{oC}$ (or $105 \mathrm{oC}$ ) at least $3 \mathrm{hr}$ prior to use. Oven should return to temperature within $1 \mathrm{hr}$ after samples have been placed into it.

7. Leave uncovered samples in oven for $24 \mathrm{hr}$ at $100 \mathrm{oC}$ or $16 \mathrm{hr}$ (or overnight) at $1050 \mathrm{C}$.

8. Move samples to desiccator, placing cover on each container as it is transferred. Seal desiccator and allow to cool for at least $1 \mathrm{hr}$ but not more than 2 to $3 \mathrm{hr}$.

9. Weigh container with cover and dried sample (W6), recording weight to nearest $0.1 \mathrm{mg}$.

\section{Comments:}

- Samples should be placed in the drying oven so that air can circulate freely. Containers should not touch each other. Air movement is necessary to cool sample dishes.

- Desiccator seals should be kept clean and well greased and the lid should always slide easily on or off. If the lid "grabs," it is time to remove the old grease and apply fresh lubricant.

- Do not place the lid on the counter top with the grease side down. The grease will pick up dirt, preventing formation of a seal.

- If a lid can be directly lifted off the desiccator, either the desiccator was not properly sealed or, more likely, it needs fresh lubricant.

- Rubber stoppers in the lid should always be pliable. 
- Open a loaded desiccator very slowly after samples have cooled. A vacuum forms during cooling and abrupt opening results in turbulence which can blow samples out of uncovered containers.

- Desiccator lid should be slid open for the removal of each container and reclosed before weighing. Leaving the lid open allows samples to absorb moisture.

- Desiccant should be checked and dried periodically. It should be replaced twice annually. Use of desiccant with color indicator for moisture is recommended.

\section{Calculation: Percent Laboratory Dry Matter (Lab DM)}

If empty container is tared to zero in step 3 (hot weigh) or step 4 (cold weigh)

\section{$\%$ Lab DM = W6 - W4 / W7 X 100}

- Where $\mathrm{W} 4$ = tare weight of container (with cover) in grams

- $\mathrm{W} 7$ = initial weight of sample in grams

- $\mathrm{W} 6=$ dry weight of sample and container (with cover) in grams

If empty container is not tared to zero in step 3 (hot weigh) or step 4 (cold weigh)

$$
\text { \% Lab DM = (W6 - W4/W5 - W4) X } 100
$$

- Where $\mathrm{W} 4$ = tare weight of container (with cover) in grams

- $W 5=$ initial weight of sample and container (with cover) in grams

- $\mathrm{W} 6=$ dry weight of sample and container (with cover) in grams 
Appendix Z. National Forage Testing Association Procedure 942.05.

\section{Total Ash in Forages}

\section{Reference:}

Ash of Animal Feed. (942.05) Official methods of Analysis. 1990. Association of Official Analytical Chemists, 15th Edition.

\section{Scope:}

This procedure is applicable for the determination of ash in all types of dried, ground forages and feeds. It is not applicable for ash determination in liquid feeds or feeds high in sugar content.

\section{Basic Principle:}

A dried, ground sample is ignited in a furnace at $600 \mathrm{oC}$ to oxidize all organic matter. Ash is determined by weighing the resulting inorganic residue.

\section{Equipment:}

Crucibles, porcelain, low wide form, $30 \mathrm{~mL}$, with covers numbered with furnaceproof ink Muffle furnace with pyrometric controller

Analytical balance, sensitive to $0.1 \mathrm{mg}$

Desiccator, with vented lid

Drying oven

\section{Reagents:}

None.

\section{Safety Precautions:}

- Use standard precautions when working around electrical equipment or glassware.

- Make sure that electrical equipment is properly grounded and installed and maintained by qualified electricians.

\section{Procedure:}

1. Remove crucibles with cover which have been dried for at least $2 \mathrm{hr}$ at $100 \mathrm{oC}$ from oven, to desiccator. Cool, and record weight of crucibles with cover to the nearest $0.1 \mathrm{mg}$ (W1).

2. Weigh 1.5 to $2.0 \mathrm{~g}$ of sample into the crucible, recording weight of crucible with cover and sample to the nearest $0.1 \mathrm{mg}$ (W2).

3. Ash in furnace at $600 \mathrm{oC}$ for $2 \mathrm{hr}$ after the furnace reaches temperature.

4. Allow crucibles to cool in furnace to less than $200 \mathrm{oC}$ and place crucibles with cover in desiccator with vented top. Cool and weigh crucible with cover and ash to the nearest $0.1 \mathrm{mg}$ (W3). 


\section{Comments:}

- Time and temperature described must be adhered to closely.

- Samples should be placed in ashing furnace so that air can circulate freely. Crucibles should not touch each other.

- Slide the desiccator lid open. Do not place the lid on the countertop with the grease side down. The grease will pick up dirt, preventing formation of a seal.

- Seals should be kept clean and well greased and the lid should always slide easily on or off. If a lid "grabs," it is time to remove the old grease and apply fresh lubricant.

- If a lid can be directly lifted off the desiccator, either the desiccator was not properly sealed or, more likely, it needs fresh lubricant.

- Rubber stoppers in the lid should always be pliable.

- Crucibles should not be packed excessively tight in a desiccator. Air movement is necessary to cool crucibles. Crucibles should not touch each other.

- The desiccator lid should be left open for minimal amount of time.

- Desiccant should be checked and dried periodically. Replace desiccant twice annually or more often depending on use. Use of desiccant with color indicator for moisture is recommended.

- Open a loaded desiccator very slowly after samples have cooled. A vacuum forms during cooling and abrupt opening results in turbulence which can blow samples out of crucibles.

- If determining ash after fiber analysis, set furnace at $5000 \mathrm{C}$ and ash until carbon-free and grey ash color ( 3 to $5 \mathrm{hr}$ ). Lower ashing temperatures require longer ashing times.

- Higher temperatures will melt glass and ruin filter crucibles. A practical maximum service termperature for pyrex glass is $5100 \mathrm{C}$ and the annealing temperature is $5600 \mathrm{C}$.

Calculation: Percent Ash, DM basis

$\%$ ASH (DM basis) $=($ W3 - W1)X 100 / (W2 - W1 ) X Lab DM/100

- $\mathrm{W} 1=$ tare weight of crucible in grams

- $\mathrm{W} 2$ = weight of crucible and sample in grams

- $\mathrm{W} 3$ = weight of crucible and ash in grams

\section{Quality}

Control: Include one or more quality control (QC) samples in each run, choosing QC samples by matching analyte levels and matrices of QC samples to the samples in the run. Include at least one set of duplicates in each run if single determinations are being made. 
An acceptable average standard deviation among replicated analyses for ash is about 0.10 , which results in a warning limit (2s) of about 0.20 and a control limit (3s) of about 0.30 . Plot the results of the control sample(s) on an X-control chart and examine the chart for trends. Results outside of upper or lower warning limits, 2s (95 percent confidence limits), are evidence of possible problems with the analytical system. Results outside of upper or lower control limits, 3s (99 percent confidence limits), indicate loss of control and results of the run should be discarded. Two consecutive analyses falling on one side of the mean between the warning limits and the control limits also indicate loss of control. 